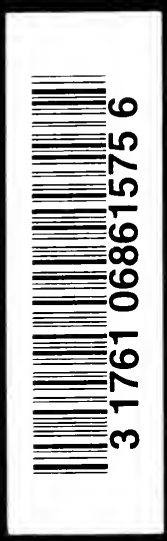


Digitized by the Internet Archive in 2007 with funding from

Microsoft Corporation 



\title{
R5985s
}

\section{STUDIES IN POLITICAL}

AND

\section{SOCIAL ETHICS}

\author{
BY \\ DAVID Ge. ${ }^{\text {rege }}$ RITCHIE, M.A., LL.D. \\ Professor of Logic and Metaphysics in the University of St. Andrews \\ Late Fellow and Tutor of Jesus College, Oxford \\ Author of "Natural Rights," etc.
}
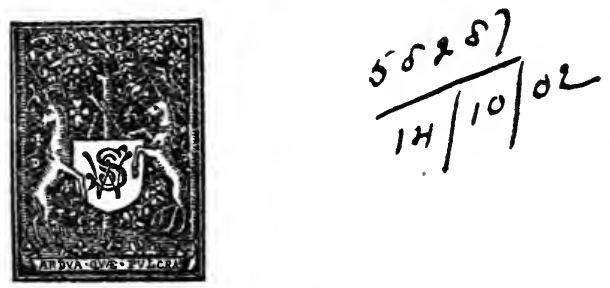

\section{LONDON}

SWAN SONNENSCHEIN \& CO., LIMITED

NEW YORK: THE MACMILLAN CO. 
PRINTED BY

HAZELL, WATSON, AND VINEY, LD., LONDON AND AYLESBURY. 


\section{P R E F A C E.}

T HAVE to thank the editors of The Inter1 national Journal of Ethics and The Contemporary Review, the Committee of the Co-operative Wholesale Society and the Committee of South Place Ethical Society, Finsbury, for their kindness in sanctioning the re-publication of articles and lectures which they first put in print. These are here reproduced with a few verbal alterations and some slight modifications of statement. But, on the whole, they have been left in their original form. As will be seen, the papers here collected together were written at considerable intervals of time and adapted to different hearers or readers; and the same subject is often approached from various starting-points. What is said in one paper must be taken as qualifying or supplementing what is said in another.

Any one trained in philosophical studies who iii 
may look into this volume may, perhaps, have to be reminded that these essays and addresses, from the circumstances of their origin or first publication, are "exoteric discourses." It seems to me possible and profitable to discuss practical questions of political and social ethics on the basis of what may be called evolutionary utilitarianism, without raising, or at least without discussing, metaphysical questions, provided that one may take for granted that faith in the value and meaning of human society and human history which is implied in all serious political and social effort. I hold, indeed, that a thoroughly scientific treatment of ethics is impossible without a philosophical basis; and that this faith, of which I have spoken, in the ultimate rationality of the world can only find a theoretical justification in a metaphysic or, in the Aristotelian phrase, in a theology. 


\section{CONTENTS.}

I.

SOCIAL EVOLUTION.

The Relation of Sociology to Biology, I-3. The Theory of Natural Selection applied to Human Society, 4-r3. Criticism of Mr. Benjamin Kidd's Application of the Theory to explain the Influence of Religion upon Society, I4-22. Race and Nation distinguished, 22-26. Bearing of the Theory of Natural Selection upon the Question of Socialism, 26-29.

II.

EQUALITY . . . . . . . $30-42$

The Dogma of Equality, 30; How far contradicted by Science, 3 I-33. Equality or Inequality on Utilitarian Principles, 34-36. Mischief of Appeals to Abstract Justice, 37, 38. Equality as Part of a Social Ideal, 38, 39. Useful and Harmful Inequalities, 40-42. 
III.

LAW AND LIBERTY: THE QUESTION OF STATE INTERFERENCE • . • 43-65

(I) 'The Prejudice against Government, 43-47. Mr. Herbert Spencer's Distrust of the State, 48, 49. The State and Voluntary Associations, 4953. State Action does not necessarily imply Extreme Centralization, 53, 54. The Rights of Minorities, 54, 55 .

(II) "Interference" not always antagonistic to Individual Liberty, 55-58. The Principle of "Equal Liberty," 58-6r. "An Equal Start," 6I, 62. Utilitarian Tests applied ( $\mathrm{I}$ ) to Compulsory Education 63,$64 ;(2)$ to a Censorship of the Press, 64, 65.

IV.

CIVIC DUTIES AND PARTY POLITICS . . 66-IO7

Political Duties distinguished from other Duties of the Good Citizen, 66-69. Grounds on which Political Duties are neglected, 69-72. What the State can, and what it cannot, do, 72-77. Evils of Party Politics, 78. Use of Parties, 79, 80. Party Government in Great Britain, 81-84. Parties in the States of Continental Europe, 8487 ; in the United States of America, 87, 88. 
The Responsibility of the Elector, 89. Compulsory Voting, 90. Advantages and Disadvantages of Party Government, 91, 92. Possible Breakdown of Party Government, 92, 93. The “Mugwump," 94, 95. The Referendum, 95-98. Local Politics, 99, 100. Public Opinion, I00-102. The Study of Politics, I02-I07.

I792.-YEAR I. . . . . . . IO8-I33

Commemorations, National and Religious, ro8II 2. "The Bible of History," Ir3, Ir4. The French Revolution, II4-II6. Hopes and Disappointments, I r6-г20. "The Ideas of '89," how far successful, r21-126. The New and the Old, I 26-129. The Judgment of History, I30, I3I. Faith in Humanity, I32, I33.

VI.

WAR AND PEACE. . . . . . . I34-I76

External Politics inevitable, 134, 135. The Quaker View of War, I36-138. Does the New Testament condemn War? I39, I40. Augustine 
and Thomas Aquinas, 141, 142. The XXXIX. Articles and the Westminster Confession, I42-I 44 . Archdeacon Paley, I44-146. "Self-defence" ambiguous, I46-I48. Our Judgments on some typical Wars between 1770 and $1870,148-152$. Is there any General Principle? I52, I53. Distinction between the Occasions and the Deeper Causes of Wars, 154-156. The Judgment of History, 157. City State, Nation, Empire, 157, 158. Different Types of "Empire," I58-160. Idola fori in Politics, 161,162 . Non-intervention, r62165. Reduction of Armaments, 165,166 . Laws of Civilized Warfare, 166, 167. Arbitration, 167-169. Kant's Perpetual Peace, r69-r7o. Suggestions from the Swiss Confederation, I70-I 7 r. Note on the Principles of the Peace Congresses, I $_{72-1} 76$.

\section{VII.}

THE ULTIMATE VALUE OF SOCIAL EFFORT I77-I99

Ethics apart from Supernatural Sanctions, 177 , I 78 .

(I) Social Well-being as the Ethical End, I79, 180. Moral Judgments as determined thereby, 181. "Humanist" and Christian Ethics, 182I 84 .

(II) Pessimism, 185-189. Sympathy, 189, I90. Social Despair and Social Faith, I9I-194.

(III) The Ideas of God, Free-will and Immortality, r 94-r 99 . 


\section{I.}

\section{SOCIAL EVOLUTION. ${ }^{1}$}

THE question that I propose to consider-at 1 least in some of its aspects-is this: What light do biological theories of evolution throw upon the history of human society and on the practical problems of human society? The phrase "social evolution," as generally used, implies the assumption that biological conceptions do throw some light on social phenomena; it generally implies, also, that without biological theories and conceptions social phenomena cannot be properly studied nor social problems scientifically dealt with. It is very often assumed that some knowledge of biological conceptions is a sufficient equipment for the study of social phenomena; and it is sometimes even implied that with the help of a few formulæ that have, or seem

1 This paper was read before the Cambridge (England) University Ethical Society, and printed in the International Journal of Ethics, January, 1896. 
to have, the sanction of biological science, the sociologist can solve theoretical and practical problems which have baffled historians and politicians for centuries.

At first sight there seems something reasonable in the view that biology supplies the key to sociology. Whatever else human beings may or may not be, at least they are living beings, subject to the laws of biology, or (to express the matter without any element of misleading metaphor) illustrating the same laws as all other living beings do. On the other hand, the greater complexity of social life among human beings, as compared with what may be found even among the social animals,-still more, as compared with anything that may be found among plants,-may well suggest that biological conceptions cannot without criticism, perhaps not without considerable modification, be applied to social phenomena. There is an important truth suggested in Mr. Spencer's description of society as "superorganic." A consideration of the superorganic character of human society may help to explain the suspicion with which the historical student, immersed in his particular problems, is apt to regard the generalizations under which the "sociologist" is in haste to bring the chaos of miscellaneous facts accumulated by the industry of antiquarians and the 
enterprise of travellers. The sociologist (especially when he is simply the biologist sociologizing) is apt to regard the historian as merely occupied with the higher gossip; on the other hand, the contempt for distinctions of time and place, and the unscholarly use of authorities, which too often characterize the sociologist, are apt to make the very word "evolution" stink in the nostrils of the genuine historian. "Evolution" and "development" seem only grand names for history treated inaccurately.

It is worth noting that in every period the prevalent notion of what constitutes "scientific" treatment depends upon what happens to be the predominant and victorious science of the time. In the seventeenth century, to treat a subject "scientifically "meant to treat it mathematically, however ill adapted the material might be for such treatment. The warmest admirers of Descartes and Spinoza do not generally think that their treatment of philosophical questions gained from the fact that the ideal of the mathematical sciences was always before their minds. In a later period, we know how the analogy of chemistry influenced the associationalist psychologists. Biological conceptions are certainly less inadequate than mathematical, physical, or chemical conceptions in the treatment of the problems of human society; but an uncritical use 
of them in a more complex material means a constant risk of mistaking metaphors for scientific laws. To adapt a phrase of Bacon's, we might say that the conception of evolution which is adequate in the biological sphere is nevertheless subtilitati rerum humanarum longe impar,_- "no match for the subtilty of human history."

Let me illustrate this by considering the applicability of the idea of natural selection to human society. Whatever view be held as to the truth or falsehood of the Lamarckian theory of useinheritance, all biologists and all sociologists would admit that natural selection is a real cause at work in human society. The only question in dispute is as to the range of its operation and as to the degree in which it can explain the phenomena. The question for the biologist is: What other factors, if any, are there in organic evolution? The question for the sociologist is more complicated; for he must not assume without proof that there are no other factors in social than in organic evolution, nor that natural selection means exactly the same thing in human society that it does among plants and animals.

There is an error that is still not uncommon in the popular application of biological theories to social questions. The phrase "struggle for existence" is often taken as if it applied specially to conscious 
struggling or fighting. Now, industrial and commercial competition is far more closely analogous to the struggle for existence in the organic world than is a war between tribes or nations. The "peaceful" or "friendly" rivalry, as it is sometimes called, between individuals competing for employment is the struggle for existence in its strict biological sense. Such competition, if unchecked, ends in the survival of the fittest-i.e., of the fittest to survive under the particular conditions-and in the starvation of the unsuccessful. If the competition does not end in the starvation of the unsuccessful, that can only be because there are other factors at work than natural selection. On the other hand, although war is one aspect of natural selection among human beings, the military organization of a tribe or nation for the purposes of attack or defence necessarily involves a mitigation and partial cessation of natural selection within the tribe or nation. So far as the history of the world has yet gone, war has been a more important factor than industrial competition in producing social organisms as distinct from mere social aggregates. We can see this even in the purely economic sphere. As the carcase brings the vultures together, so the material of an industry and the presence of consumers may collect the workmen; but it needs a struggle with employers, 
or with some other set of workmen-i.e., it needs industrial war to produce organization among them, and to make them something else than merely competing individuals.

In using the phrase "social organism," it is necessary to remind ourselves that in all human societies, except the most rudimentary, every individual belongs to more than one social organism, and that a struggle is possible between the different organisms to which the same individual belongs. Family, clan, city, nation, church, university, club, social caste or class, each of these is a social organism, competing with like organisms and often with one another in the struggle for existence and in the struggle for the allegiance of their individual mombers. Now to this there is nothing analogous in the purely biological sphere. The domestic animals, with a divided allegiance between their kindred and their human friends or masters, are "an exception that proves the rule"; for they are slaves of mankind, and so quasi-members of human societies. Thus, in applying the conception of natural selection to human beings, we have to recognize that there is not merely the struggle for existence between individuals competing for food and for the opportunity of producing and rearing offspring, but also, and to some extent interfering 
with this "natural" struggle, there is the struggle between societies; and, secondly, we have to recognize that these societies are of different kinds, so that an individual may belong at the same time to flourishing and to decaying social organisms, and the same individuals may be rivals in certain relations and allies in others. When, therefore, the biological moralist tells us that certain things are injurious to the social organism, it becomes important to ask him "to which social organism ?"

Natural selection, in its biological sense, means the death of the less successful. So far as the conception in this sense is applicable to the explanation of human history, it means that certain races and certain customs have survived because other races and those observing other customs have perished. But we should be strangely ignoring the facts of history, and of the world that we know in our own experience, if we supposed that it was only through the slow and deadly process of natural selection that the various elements in our civilization have been produced, preserved, and diffused. Even among the higher social animals lower than man, a great many habits are due to imitation and not to instinct-i.e., they are transmitted in the social inheritance of the race, and are not dependent on 
heredity, in the biological sense. Thus, birds learn how to build their nests, partly at least, by example and individual experience. It has been noticed that young swallows do not build so expertly as older birds. Among pigeons the art of bringing up a family is learned by the less experienced from the more experienced. Among butterflies, on the other hand, all habits that make for the welfare and success of the race must be due to inherited instincts (the butterfly, e.g., never sees its offspring as butterflies; education is thus impossible); and if "natural selection" accounts sufficiently for such instincts, that means that individuals not possessing the necessary instincts in sufficient degree are constantly perishing. Among human beings, on the other hand, while inherited instincts, produced and preserved by natural selection, undoubtedly exist, we must avoid the mistake of exaggerating their number and range ; for social inheritance is relatively more important as we advance in the scale of development. The prolongation of infancy makes education necessary and possible; and the helplessness of the young may thus be regarded as the source of civilization-i.e., of all that separates man from the mere animal. The rudiments of social inheritance, as I have just pointed out, already exist among the vertebrates lower than man; 
but language enormously extends its power and importance. Tradition, acquired experience, and definite institutions can be handed down from generation to generation altogether irrespective of biological heredity, and may therefore be handed on from one race to another.

Now, in all this there is nothing inconsistent with the theory of natural selection. The helplessness of infancy, the rise of language, the possibility of transmitting experience irrespective of heredity may all quite well be said to be themselves due to natural selection. But we must recognize that the existence of these elements in human society makes social evolution something very different from, and much more complex than, what can be accounted for by natural selection, as that is understood in the purely biological sphere.

Consciousness and reflection may be explained historically as the result of natural selection. Our simian ancestors who first happened to have brains which enabled them to adapt means to ends, instead of simply following their instinctive tendencies, got a great advantage over their less reflective brethren. The use of tools and of language separated them off from the others; but while securing the success of the tribe as a whole, this separation undoubtedly led to a diminution of the stringency with which 
natural selection had hitherto weeded out the animals less fitted to struggle unaided with one another and with the rest of nature. Reflection may have originated through natural selection : once originated, it can be adapted to purposes which seem to have no bearing on the advantage of the individual or the species in the struggle for existence; such purposes, for instance, as mathematics and metaphysics, which to Mr. Russel Wallace seem inexplicable by natural selection. What is originated for purely practical ends may be adapted to ends that are of no obvious or immediate practical utility; and thus we should be prepared to find in human society many phenomena that cannot be accounted for directly by natural selection, and some even that seem to conflict with its operation, at least through considerable periods and over large areas. Reflection directed to individual and social utility may suggest the adoption of courses which prove in the long run to be socially injurious and lead to the injury or extinction of the race that has adopted them; but in other cases reflection may lead to the alteration of injurious customs whose ill effects natural selection would have proved too late for its lessons to be of any use. Thus in social evolution natural selection is often supplemented and partially supplanted by artificial selection, such artificial selection being 
sometimes injurious and sometimes beneficial. Natural selection tests the social utility of customs and institutions too late for the benefit of those concerned: utilitarianism-if by utilitarianism be understood a consideration of social well-being-is the attempt to anticipate social utilities and thus to avert, where possible, the cruelty of natural selection. But in asserting that human society presents many phenomena that cannot be accounted for by natural selection in its purely biological sense, I am not denying the truth of the theory, but rather extending its range. There is going on a "natural selection" of ideas, customs, institutions, irrespective of the natural selection of individuals and of races. Below the level of conscious adaptation of means to ends, a habit which was once beneficial, but which through change in the environment has become injurious, can only disappear through the extinction of all the individuals practising it. Where there is consciousness and reflection, the habit may be changed without the extinction of the race. Thus, we have to notice two marked differences between human and sub-human evolution: (I) As I have just been pointing out, customs and institutions may perish without the necessary destruction of the race that practised them; and (2), as I pointed out before, customs and institutions may be handed on 
from race to race, and may long survive the race among whom they originated.

When we find any persistent characteristics in a species of animal-e.g., an organ shaped in some particular way, a particular colour or arrangement of markings, a peculiar habit, etc.-we are justified in using natural selection as a clue to an explanation ; that is to say, we are justified in asking ourselves, What advantage does, the species get through this peculiarity? But even in the case of organic evolution we must be on our guard against the supposition that everything is due to natural selection. Thus, certain peculiarities may possibly be due to sexual selection,-a luxury which is permitted to certain species where natural selection is not too severe. Certain peculiarities, again, may be survivals, which are harmless, or at least not sufficiently injurious to have disappeared. Thirdly, wherever we have any relative cessation of natural selection, we have panmixia-e.g., where animals are under domestication, we have a greatly increased variation in colour and markings; apart from any special artificial selection, this is due simply to the animals being defended against their enemies of the wild state, so that those without the specially protective colourings are not killed off. Now, in human society it is reasonable to expect that every 
one of these causes will operate more largely than in the sub-human sphere. The formation, for purposes of attack and defence, of compact groups of human beings causes a diminution of natural selection within each of the groups; artificial selection of all sorts goes on under the influence of ideas and sentiments of various kinds, religious beliefs, caste prejudices, etc. Survivals are rendered still more possible than in the biological sphere, because of the relative cessation of natural selection within large groups ; and, for the same reason, there occur variations of all sorts and "bye-products" (Weismann's phrase) which are not constantly weeded out by natural selection.

Thus the theory of natural selection when applied to human society sets a problem, but does not solve it. In illustration, let me take first the case of religion. Everywhere human societies have some sort of religion, if we adopt a sufficiently wide definition of religion in order to cover the enormous diversity of practices and beliefs which for the purpose of scientific study we have to include under the name, a diversity so great that the acts which are commanded by one religion may be condemned by another, and that what seems essential to religion in the minds of some people (e.g., a belief in a future life, or a belief in a personal God) may be altogether 
or nearly altogether absent from the religions of other great sections of mankind. Now the thcory of natural selection suggests, as it has suggested to Mr. Benjamin Kidd, that religion must cverywhere further the success of a society. Religion, according to Mr. Kidd, is what induces the individual to subordinate his interests to those of the social organism. This opinion is, I take it, arrived at solely by a deduction from the general theory of natural selection. At least, I do not find that Mr. Kidd has made any attempt to prove from history that all religions have, had that effect in all the societies which have practised them; and it is in that wide form that the proposition would need to be proved in order to justify his statement inductively. Religion exists everywhere among human beings; therefore, it must be due to natural selection; therefore, its essence is to further social utility. Such, I take it, is Mr. Kidd's argument. The curious thing is, that exactly the same argument might be applied to the case of reason. Reason exists everywhere among human beings; but Mr. Kidd regards reason as everywhere antagonistic to the interests of the social organism. I do not intend to press that objection, however, because, in the one case as in the other, I regard the statement as far too general and sweeping to be of any scientific value. I shall quote 
Mr. Kidd's definition of religion "in the sense in which alone science is concerned with religion as a social phenomenon": "A religion is a form of belief, providing an ultra-rational sanction for that large class of conduct in the individual where his interests and the interests of the social organism are antagonistic, and by which the former are rendered subordinate to the latter in the general interests of the evolution which the race is undergoing." Now, with regard to this statement, there are some questions one would like to ask. (I) Which race-the whole human race, or a particular race? (2) Which social organism-the particular political society to which the individual belongs, or some future society? The interests of a particular race are not identical with the interests of the human race as a whole: an individual might be furthering the interests of the human race as a whole, while helping on the destruction of his own particular race. And, as I have tried to indicate already, an individual may belong to many social organisms, and some of these may be wholly or partly antagonistic to one another; so that conduct which furthers the interests of one may be directly or indirectly injurious to the interests of another.

I need not apologize for referring specially to Mr. Kidd's views, as "social evolution" has recently 
been associated in the minds of many with his book. Mr. Kidd has certainly done a good service by calling the attention of the general public - the public which has given his book so cordial a welcome-to the significance of religion for the science of sociology, in all its branches, and in both its theoretical and practical aspects. $\mathrm{He}$ is indeed under a strange delusion in thinking that scientific students of society have ignored the social significance of religion. The opening passage of Professor Marshall's "Political Economy" might be cited as a conspicuous testimony: "The two great forming agencies of the world's history have been the religious and the economic." What is quite true is that the place of religion in human history is too often the subject merely of ecclesiastical or of anti-ecclesiastical declamation; or else, through fear of giving offence, it is left severely alone. This last attitude has been the preparation for the scientific attitude, but is not itself scientific.

But I cannot see that anything is to be gained by discussing the question of the significance of religion for social evolution in such a highly generalized form as that in which it is put by Mr. Kidd. Indeed, if we define religion as he does,-as something which necessarily tends towards social progress,-it becomes meaningless to ask what the social significance of 
religion is. That is already answered in the definition, although, as I have just shown, the words "race" and "social organism" are left ambiguous But the really important and interesting question remains unanswered: Which of the religions of the world, known to the ordinary man and to the scientific student of religions, are "religions" in Mr. Kidd's sense of the term? One of the problems which most puzzles the careful student of human history is presented by the apparently anti-social and injurious elements contained in so many of the world's religions. This very matter has been urged as an objection to the applicability of the theory of natural selection to the explanation of social evolution. Has not the fear of the gods, from which the brutes are free, stood in the way of mankind in their struggle with nature? The pursuit of science, which has surely in some cases been of some social utility, has in all ages exposed men to charges of impiety It might be plausibly argued, indeed, that pilgrimages, by promoting pestilence, exercise a severe natural selection, and that cannibalism, which is in most cases connected with religion, has produced the survival of the toughest; but it is difficult to see how human sacrifices, mutilation, extreme asceticism, the perpetual celibacy of large numbers of picked persons, have promoted the social efficiency 
of the races which have adopted such practices under religious sanction,-least of all, if social efficiency is mainly promoted, as Mr. Kidd seems to think, by a teeming population multiplying in excess of the means of subsistence.

Now, I do not think such objections so fatal to the social utility of religion generally as they may at first sight appear. The conditions of social well-being are very complex, and great gains in certain directions may compensate for many drawbacks in others. Thus, there can be no doubt that in all primitive conditions of society religion is the strongest bond of social cohesion. Elements in it which, taken by themselves, are anti-social or injurious in character, if they have tradition and long-established custom in their favour, may persist without doing sufficient injury to outweigh the social gain that comes from the religion as a whole. But the social utility of such a religion comes not from its irrational character, but in spite of it, and because it is the common religion of the whole tribe or nation. That is why primitive religions, though they may contain very little dogma, cannot tolerate dissent from the customary observances, and are apt to be jealous of the introduction of new-i.e., foreigngods. Religions of the primitive type are thus among the strongest of conservative forces in a 
society, and among the strongest of bonds uniting its members to one another, and at the same time separating them from those of other societies. But religion is certainly not the sole bond of union between human beings, nor is a conservative force necessarily under all circumstances beneficial. Independent of, and prior to, all religious sanctions there is a social instinct which exists among all gregarious animals; the observance of a common ritual enormously strengthens the unity of a social organism, but it is not something that comes into existence out of nothing. On the other hand, it must be noted that what under certain conditions promotes social well-being may, under changed conditions, come to injure it. Extreme conservatism and antagonism to outside influences, which are a strength in certain relations, prove a weakness in others. This is true not only of primitive tribal religions, but of religions professedly universal in character. Thus some of the very same elements, which make Mohammedanism promote the social efficiency of its converts from lower types of religion, make it socially injurious when confronted with Western civilisation. So, too, the organization of the Latin Church in the middle ages provided the rigid discipline which alone could mould the barbarians, who had overthrown the Roman Empire, 
into orderly and civilized nations; but this same mediæval system, wherever it has remained unaffected by rationalism in regard to beliefs about nature and the supernatural, and in regard to the conduct of politics, has proved an impediment to national progress and prosperity.

Universal religions, including Buddhism, Mohammedanism, and Christianity, present a much more difficult problem to the sociologist than primitive tribal religions, or than the national religions of the great peoples of antiquity. A universal religion, so far as it is true to its ideal, breaks up the bonds of nationality and even of kinship, although it may go on to create a new social organism,-a churchi.e., a community of creed, not of race or political allegiance. What we actually find is, of course, a compromise between such an ideal and the older type of purely tribal or local religions. We find a universal religion professed which influences human conduct to some extent, while the greater part of people's lives (I am speaking of the ordinary, average person, not of the enthusiast nor of the criminal) is regulated by the social inheritance of their particular country, or of the class or caste to which they belong.

Thus, if it be asked, "What is the effect of religion on the interests of the race or on the interests of 
the social organism?" it seems to me all-important to know not merely what race and what social organism are meant, but what religion. Nay, even if the question be asked about the Christian religion, it is still necessary to know which Christian religion? The religion of the hermits of the Thebaid is not quite the same thing, for the purposes of sociology, with the religion, say, of the ordinary English or American citizen of the present day. And if one wishes to settle any definite question,--say, how far the spread of Christianity led to the decay of the Roman Empire, or how far the decay of Spain was due to the ruthless suppression of heresy,-it is surely better to consult the historian who has made a special study of the particular causes at work in each case than to have recourse to any sweeping formula about religion in the light of biological science, with whatever oracular solemnity that formula may be propounded.

The antithesis which Mr. Kidd, like many other pecple, finds between reason and religion seems to me based on a very inadequate psychology and on a very inaccurate reading of history. Reason may often lead individuals to act in an anti-social fashion : does not religion, especially if it be of an irrational kind, often lead them to act in a fashion quite as anti-social? The religion which has helped to create 
and further so many movements of social reformation in modern times is a religion which had inherited a large part of the rationalism of Greek philosophers and Roman legislators, and which, at least in Protestant countries, has come more or less under the influence of modern science. It may be perfectly true that mere anti-religious rationalism would in the long run lead to a selfishness destructive of social cohesion, and so become a cause of national decay; but it is perfectly certain that, under the conditions of modern life in civilized countries, in proportion as religions remain uninfluenced by rationalism, they become sources of national weakness and not of strength.

But, when we speak of "national decay" or of "social progress," there is an ambiguity in the phrases which the biological sociologist is apt to overlook. From the point of view of biology and of natural selection in its biological sense, the only matter of interest is the continuity and persistence of the race. For the sociologist there is an important difference between a race and a nation. Nationality is usually based on race, to some extent at least; I do not think the facts of history justify us in considering it as necessarily based on race. If a people think they are of the same race, and if they speak the same language, have the same traditions, and 
through geographical conditions or the pressure of economic and political circumstances have come to have a community of interests and of aspirations, these are far more important factors in the sentiment of nationality than a racial identity such as would satisfy a careful ethnologist classifying mankind according to the shape of their skulls and the characteristics of their hair. Switzerland shows that a nation may exist in spite of diversities not merely in race, but in language, in religion, and in past history. Switzerland is a living refutation of merely ethnological solutions of political problems. A nation (Volk) is, to use the convenient term of German political science, a Culturbegriff, not a Rassebegriff; it implies a community of civilization, not necessarily a community of race. Now we have already seen that in social evolution the transmission of a type of civilization is possible independently of the continuity of the race; so that a race may be even dwindling in numbers whilst its type of civilization may become more and more diffused, because more fitted to survive in the struggle for existence with other types of civilization. Thus the decay of a race is not necessarily the same thing as the decay of the nation with which in some past time that race was identical. I do not mean to deny that in the struggle between nations the dwindling of a once 
dominant race may become a very serious source of weakness; whether that be so or not depends on many other considerations. What I wish to urge is, that for national continuity the assimilative power of the national civilization may be of far more importance than the mere numerical increase of the race which originally formed the nation. When the Spartan race dwindled, the Spartan State necessarily decayed, because the race was the State. On the other hand, every one of the Roman families that fought against Hannibal might have been extinct in the time of the Antonines ; but the "Roman people" was becoming nearly identical with the civilized world. If no descendant of the "pilgrim fathers" survived on the American continent, the main characteristics of the New England type of civilization might still predominate over the vast multitudes from all lands which that type of civilization is assimilating. To the biologist, the dwindling number of births in France and the rapid increase of the German people are the sole significant factors ; they are not the only factors of which the sociologist should take account. Nearly every foreign immigrant into France is, if he settles there, assimilated by the French nation. Run over some names recently conspicuous in French politics: MacMahon, Waddington, Gambetta, Spuller, Waldeck-Rousseau, 
etc. On the other hand, nearly every emigrant of the overcrowded population of Germany is lost to German nationality, and is in a few years speaking the English tongue, and becoming an heir to the institutions and traditions of the United States or of some British colony. There is one part of the world where the French race remains almost entirely under the influence of a religion which is sufficiently non-rational to satisfy Mr. Kidd's definition; and there the race certainly increases with a rapidity that outruns the means of subsistence. They would increase more rapidly still, were it not that (as Mr. Goldwin Smith has remarked) under the influence of their religion they trust to little images of the Virgin instead of to vaccination as a security against the ravages of small-pox. It is, of course, possible, though it seems hardly likely, that the French Canadians will become a more important factor in the history of the world than the French nation has been. But I can fancy many a patriotic Frenchman, if the choice were offered him, preferring that his country's literature should be admired throughout the civilized world rather than that his descendants should be swarming in the tenement-houses of American manufacturing cities. And if we recur to the case of Germany, I think the influence of the German universities on the picked students of 
America is a far more important element in determining the German factor in American civilization than the swarms of Teutonic immigrants.

In arguing for the possibility of national progress irrespective of racial increase, and even of racial continuity, I must guard against misunderstanding. I do not mean that a community, consisting mainly of negroes, or perhaps even of Mongolians, could carry on our "Western civilization" without that civilization suffering in quality. I only mean to urge that mere increase in numbers is not necessarily the sole or the best way of preserving a type of national existence that seems worth preserving. A people may be more socially efficient whose "standard of living" is not perpetually lowered by an increase in excess of the means of subsistence, provided always (and this is the commonly neglected element in the population question) that natural selection is not replaced by an artificial selection of the unfittest.

This brings me to the last point $I$ intend to consider-viz., the bearing of the theory of natural selection on the question of socialism. According to Mr. Kidd, the tendency of the movement now proceeding in the Western world is not towards socialism, as that is commonly understood; social cvolution does not diminish competition, but brings 
all mankind into the rivalry of life on conditions of equal social opportunities. Competition seems certainly most in accordance with natural selection in its biological sense, but Mr. Kidd speaks of natural selection becoming "humanized" through . the operation of the "altruistic sentiment" which has permeated society as the effect of the Christian religion. Now, two questions suggest themselves: (I) How can natural selection be humanized without ceasing to produce the survival of the fittest? All philanthropic interference with the starvation of the unsuccessful means a certain amount of artificial selection, which hinders the racial progress that would be produced by unchecked natural selection. To get the real benefits of natural selection, we should require not merely to give up all philanthropy, but to abolish all such institutions as inheritance of property, marriage for life, probably all law and order,--everything that separates us from the animals. Simply to abolish all factory Acts and land Acts and sanitary Acts-in fact, so far as Great Britain is concerned, all the laws passed since 1846 , with perhaps the disestablishment of the Church and the abolition of the House of Lords thrown in-would leave us still very far away from the region of unimpeded natural selection. Biological students of society see perfectly clearly that all 
humanitarian legislation brings with it a certain deterioration in the vigour of a race, ${ }^{1}$ unless those unsuccessful individuals whom altruistic sentiment will not permit us to see eliminated by starvation are rigorously segregated from the vigorous portion of the community, and prevented from producing offspring. This latter course would be a method of rational artificial selection by which we could bring about in less cruel fashion the race progress that otherwise can only be obtained by leaving natural selection to do its work unchecked. The difficulty in the way of any nation adopting such rational artificial selection will probably arise mainly from the non-rational religious sentiments which Mr. Kidd thinks essential to social progress. (2) How can "equal social opportunities" be secured for all mankind, or for any portion of mankind, without a complete organization of industry being undertaken by the State-i.e., without collectivist socialism? If the "friendly rivalry" on conditions of "equal social opportunity" only means that the well-equipped and the ill-equipped in mind, body, and estate are to be allowed to start together in the race, the loser to be killed by starvation, that is certainly natural selection, but the "equal social

1 See, e.g., Professor J. B. Haycraft's Darwinism and Race Progress. 
opportunity" is a mockery and a sham. If, on the other hand, the loser is to be treated through altruistic sentiment as kindly as the winner, the work of natural selection is frustrated, and the well-being of the race is injured. If the equal social opportunities are to be made a reality, and such deterioration in the quality of the race is to be avoided, we must, in the first place, have a socialistic organization of industry, and, in the second place, a system of artificial selection such as the average socialist, who is apt to be an anarchist at heart, has hardly ever contemplated,-a system, however, which was proposed long ago by Plato in his Republic, when he argued that the breeding and rearing of citizens should be regarded with at least as much care as the breeding and rearing of dogs and horses.

These are problems of social evolution which I do not think can be profitably discussed in disregard of biological science; but I do not think they can be settled by any dogmatic application of biological formulæ. 
II.

\section{EQUALITY.}

" THAT all men are by nature free and equal"

1 has been proclaimed again and again in French and American "declarations of rights." Bentham was a sworn foe to those abstract declarations, and yet Bentham's principles in ethics and politics assume the natural equality of mankind. In his "moral arithmetic" it is taken for granted that "every one is to count for one and nobody for more than one." John Stuart Mill asserts that, though for certain purposes inequalities have to be recognised, yet the presumption is always in favour of equality. If we turn from Utilitarianism to the ethics of Kant, we find the same assumption of equality. Every man, simply as such, is to be

1 This paper appeared in the Contemporary Review (October, 1892) and also in a German translation, in Deutsche Worte (December, 1892), where, by an editorial error, it was spoken of as the work des bekannten Staatsmannes (the Right Hon. C.T. Ritchie). 
considered an "end-in-himself"; and Kant makes the principle of equal freedom the basis of his jurisprudence. All those, of whatever ethical or political school, who in any sense accept what are called "the ideas of ' 89 " are accustomed to take for granted the theory of equality, whatever reservations or qualifications they may introduce in applying it in practice.

There is, however, one great influence on modern thinking which is, or seems, quite adverse to equality -the influence of theories of evolution. And the "Anti-Jacobin" feels that he has natural science behind him when he says, "Men are neither born free nor equal. What is the freedom of the helpless infant? What is the equality between the child of parents of the highest European type and the child of the Hottentot?" Such protests in the eighteenth century might have seemed to be simply the product of aristocratic or caste prejudice. People believed in the "noble savage"-when at a convenient distance from contact with him. But nowadays arithropology and a more scientific study of history supply convincing proof of the very great inequalities between different races; and the biologist points out that the progress of the world of organized beings depends on the inequalities among them, in virtue of which the fitter for survival come 
out victorious in the struggle. Nay, we may go farther back than biology and observe that in the whole physical universe inequalities-e.g., in size, in level, in temperature-are a necessary condition of movement and life.

Let us admit all this; let us discard the dogma of equality. But let us be careful to bow to science only, and not to any interested or prejudiced misapplication of scientific truth. Granted that, even within any particular race, there are immense differences of natural-i.e., inherited-talent and capacity, that is no sufficient reason why the degenerate great-great-grandson of an eminent man should have a voice in legislation superior to that of the chosen representative of a large number of fairly sane and sensible persons. Granted that the white races are, on the whole, much higher than the negro, that is no sufficient reason why the negro should be bought and sold like a horse or an ox, or why he should be deprived of the means of raising himself, as far as he can, by education and social opportunities. Granted that the acquisition of wealth in industrial competition is a proof of the possession of ability of a certain special kind, that is no sufficient reason why wealth alone, whether honestly or dishonestly acquired, whether acquired or idly inherited, should constitute a claim to social 
and political pre-eminence. Granted that the average woman, through the demands made upon her by nature to adapt her to the physical function of motherhood, has less bodily strength, perhaps also less intellectual power than the average man, that is no sufficient reason why a community should be deprived of the public services of its more competent women, and why all women should be deprived of the education that comes from public responsibility. If we are not entitled to apply a dogma of universal equality in an abstract way, neither must we allow the fact of natural inequalities to serve as an apology for artificial inequalities which cannot be defended on other grounds, and which, be it observed, have often very little to do with the natural inequalities that are supposed to justify them.

"That every one should receive according to his merits" is a principle of justice very generally accepted; but, save within very definite limits, is it of much practical value? That shareholders should receive dividends in proportion to the amount of their shares is equitable. Here the principle is easily applied by the help of the rules of arithmetic. But a shareholder is an individual considered only in one particular aspect and for one particular purpose. If we extend this principle of justice to 
human affairs generally, how are we to find a standard by which to estimate the "merits" of individuals? How are we to get a quantitative measure by which to determine the "amounts" they are to receive? How are we to decide between the competing claims of different sorts of excellence? Proportion may be allowed to be the "justice of the gods," but human justice has, in many cases, to be the justice of mere equality, simply because of the difficulties of assigning proportionate inequalities fairly. That is to say, we adopt equality, not as the ideally best or wisest arrangement, but faute de mieux; not believing that every man is as good as another-than which the Irish supplement, "Yes; and better too," is not more absurd-but because any system of inequalities we adopt is likely to fall so far short of ideal justice that it will provoke indignation and discontent. Disputes are often settled by casting lots.

Equality, therefore, as a principle is itself ultimately dependent on utilitarian considerations; it is a rough-and-ready device for escaping the difficulty of judging correctly and the discontent which arises from suspicion of unfair judgments. It is part of that system of compromise which has to be adopted in the regulation of human affairs. Where we cannot get a definite and easily 
discoverable line to mark off obvious inequalities, we have to content ourselves with an assumption of equality, which we know to be inaccurate. And inequality has often to be accepted on similar grounds of general expedience. Thus many young persons of seventeen or eighteen may be more mature in thought and character than others of twenty-one or twenty-two; but it is necessary to draw the line somewhere, since obviously the child of twelve is not equally capable of legal and social freedom with the man or woman of twenty-five. The line must be a definite one for the sake of convenience, and thus it will seem, in some cases, to be very arbitrary; but this is a less evil than either the hopeless attempt to determine maturity in every single case, or the cruel folly of treating children as if equal to adults. The subordination and discipline of the child is a necessary preparation for the independence of after years. "By obedience we learn to rulc." The subordination and discipline must, however, be such as to train for independence. If they are such as to render the individual utterly and permanently dependent and helpless, they are clearly mischievous.

The same principle of compromise must apply to the treatment of inferior races. A wise distinction is established among British colonies between those 
in which there is a large proportion of inferior races-in many cases, the accursed inheritance from the slave-trade-and those in which there is not; the former class are refused responsible government lest the white minority should practically reintroduce slavery, which we have come to regard as a mischievous form of inequality, or lest the black majority, having no traditions of free institutions, should make orderly government impossible. But with regard to "inferior races," it is well to remember that, though the mental furniture of the savage seems nearer to that of the higher apes than to that of civilized man, yet the brain of the savage is nearer to that of the civilized man than to that of the highest ape; so that the difference between the savage and the civilized man is due, not so much to "nature" (in the sense in which we distinguish nature from what results from human effort) as to human institutions. If, therefore, we assent to the usual plea of the dominant white caste that "those blacks must be treated like children," we do so on the express understanding that they are to be treated like children and not like cattle-i.e., that they are to be trained up to such degrees of independence as they prove themselves fit for.

With regard to equality, as with regard to freedom, 
people are very apt to fall a prey to abstraction, and in pursuit of the form to neglect the reality, preferring shadow to substance. And of this tendency on the part of social reformers, the defenders of established inequalities are ready to take full advantage. It is easy to point out how absurd and crucl would be a formal equality-beforethe-law of children and adults; how dangerous to social well-being is a formal equality in political privilege of newly emancipated slaves and their former masters, of the ignorant and those who are ready to take advantage of their ignorance. When it is proposed to enact a very salutary factory law that no woman shall be employed in a factory within a month before and after childbirth, some advocates of women's "rights" are ready to cry out against the gross inequality of a measure affecting only one sex. An abstract claim of equality is preferred to the interests of the whole race, which demand that children shall have some chance of healthy rearing. In this case, indeed, the clause might safely be made applicable to men also; abstract justice would be satisfied and no harm done. It would be an immense gain if all such questions could be discussed entirely on the basis of utilitarian considerations-i.e., considerations as to what conduces most to general social well- 
being, nothing whatever being said about "abstract justice " or " natural rights."

It has been objected that manhood suffrage or adult suffrage, irrespective of sex, is no more reasonable than babyhood suffrage, doghood, cathood, rathood, mousehood suffrage; and the objection is a valid one against those who base the claim to equal rights on the mere fact of sentience, and who, in their zeal on behalf of our brethren the animals, are fighting the cause even of the microbes that cause diseases. It will be time enough, however, for the practical politician to consider the question of animal rights when the babies, the dogs, the cats, the rats, and the mice form themselves into societies for political agitation. The fact that a class of the population are capable of uniting, and, if need be, of rebelling, is a good utilitarian reason why timely concessions should be made; but it may often be supplemented by reasons of a less ignoble-looking sort.

Among these utilitarian considerations we must not forget to include a higher plea for equality than has yet been mentioned-the consideration that only on a basis of equality is friendship possible. Friends must treat each other as if equal. "Between uncquals sweet is equal love"; but the love is only equal if the inequality is left out of sight. Where 
people associate on terms of inequality there is constraint, suspicion, cringing deference, contemptuous indifference. Aristotle says that in a democracy there is most friendship, whereas the despot can have no friends. And so we get equality as part of our social ideal-something to be striven for in order to increase social well-being by increasing the opportunities for free and unconstrained human intercourse. The truest friendship, indeed, the truest comradeship implies not merely a formal equality, not merely the social possibility of associating with others as if they were equals, but real equality, at least within a certain degree-i.e., a general equality in intellectual training, a general similarity in taste, in manners, in ideals of life. Equality in intellect, in natural capacity, can never be obtained by institutions, though marked deficiencies, bodily, moral, and mental, may be diminished more and more by attention to the laws of heredity and to the responsibilities of parentage. Complete equality in intellect-nay, even complete similarity in ideals-would be undesirable, could it be attained, because this would mean that progress was at an end; and that progress should be at an end before perfection was reached would mean, first, stagnation, and then decay.

It is all-important to distinguish between useful 
(by which I mean socially advantageous) and useless inequalities. That a community should have in it some persons with greater gifts of mind, with greater artistic powers, with greater vigour of character and a higher sense of duty than others-that it should have its sages, its saints, its heroes-is a necessary condition of healthy and progressive life. On the other hand, rank and wealth represent inequalities whose use is transitory. In certain stages of development they are the necessary conditions of any leisure and culture at all. But gross inequalities in leisure and in culture are not salutary inequalities in the long run. "Spiritual" inequalities-I am using the word "spiritual" to include intellectual and artistic and moral-spiritual inequalities are advantageous, material inequalities are not, because they do not necessarily ensure spiritual inequalities. The peer and the millionaire may sometimes be intellectually fitter associates of their parasites, the gamekeeper, the horse-jockey and the prizefighter than of the poets, artists, politicians and men of science, to whom their social patronage is often a doubtful benefit.

Real inequalities cannot be ignored. The democratic enthusiast may affect to find the companionship of the uneducated labourer more pleasant than that of the professional man whose mind never moves 
out of a narrow, conventional groove, and the intelligent artizan is undoubtedly a more profitable acquaintance than the blasé "Society" idler; but still we cannot get over a real gap which social habits and education place between different groups of human beings. There are in our present social organization real, and not merely imaginary, castes; and the barriers between them can only be removed by the extension to all of the opportunities of true culture. We cannot do much good by feigning to ignore the effects of different training; we can do the greatest good by endeavouring to place the highest existing or possible culture at the disposal of all who are fit to profit by it, instead of leaving it a monopoly of the idlers. If the man of scientific or literary attainments or the experienced politician goes and becomes a farm-hand, and lives as such, he may benefit his own muscles, his own digestion, and possibly his own soul; but if he help to secure for the toiler more leisure and those educational opportunities which make it possible to use leisure rightly, he will benefit a vast number of human beings now and in the future. It is a less picturesque form of striving after the ideal of equality; it is far more useful.

Every diminution of social inequality means a diminution of unhappiness in those who can think 
as well as feel; for to them at present "all happiness," as George Sand said, "is like a theft in this ill-regulated world of men, where you cannot enjoy your ease or your liberty except to the detriment of your fellow creatures." 


\section{III.}

\section{LAW AND LIBERTY: THE QUESTION OF STATE INTERFERENCE. ${ }^{1}$}

THE question of State interference is a very 1 large one. I shall take up only a few points that seem to me of special importance; and I shall adopt a method not unknown to pulpit-orators who are at a loss how to divide their subject. I shall take each word separately and see what can be got out of it: that is to say, in the first place let me consider the word "State"; and in the second place let me consider the word "interference." Such an inquiry is not superfluous; both words are extremely ambiguous and the source of much confusion.

\section{I.}

The prejudice against State interference is, unfortunately, only too intelligible. In most ages and in most places throughout past history the

1 A paper read before the Society for the Study of Social Ethics (Oxford), October, 1891, and printed in their Journal. 
State has meant to the mass of human beings an alien power, an authority imposing its commands on them from without. Hence, when discontent becomes conscious, when the mass of mankind find voices and leaders to express their discontent and their demands, the first demand generally is, "Leave us alone." Liberty appears as the antithesis of State action. This view of the State as an alien and hostile power is admirably expressed in one of Thomas Hardy's Wessex Tales. When the Methodist preacher tries to argue with his handsome young landlady, who is actively engaged in the smuggling business, that it is dishonest to recapture the contraband brandy-tubs which have been carried off by the excisemen, she indignantly answers him: "They are honestly bought; we paid thirty shillings for every one of them before they were put on board at Cherbourg, and if a king who is nothing to us sends his people to steal our property, we have a right to steal it back again." Robert Burns, an exciseman himself, knew he was expressing the popular sentiment when he sang:

"Mony braw thanks to the meikle black deil That danc'd awa' wi' th' Exciseman."

The State as the collector of taxes is, I fancy, universally unpopular. Yet in the matter of taxes 
it makes a great difference in what way the taxes are levied, and whether the object of taxation is generally approved or not. State interference is disliked, not simply because it is the State which interferes, but because the interference is such as would be disliked coming from any quarter. The State, as represented by a strong, despotic monarch, may be relatively popular, so far as it relieves the mass of the people from the multitude of smaller tyrants. Thus a strong ruler like Henry VIII. was in the strictest sense a popular sovereign. His oppressions were only felt by sections of his subjects, and chiefly by the nobility and the regular clergy, who had become unpopular. The absolute monarch, the modern equivalent of the Greek "tyrant," appears as "the people's friend." But when the tyranny has been established so long, that the oppressions or disorders which justified its origin have been forgotten, the tyranny in its turn becomes unpopular. If the king says, "L'état c'est moi," it makes a good deal of difference what sort of a king he is; and in the long run the principle of personal government is pretty sure to make the State unpopular. Weak, selfish, stupid despotism becomes detestable; but enlightened and benevolent and beneficent despotism is hated too. A Joseph II. may incur as much odium as a Louis XV. 
Salutary reforms-i.e., what we should judge to be such-may fail altogether of their effect, if they are attempted without regard to the sentiments and traditions of the people affected by them. It is one of the great advantages of democracy (I mean genuine democracy, not an individual or a class or a committee tyrannising in the name of the pcople) that no measure can be carried which has not a very strong public opinion behind it-an advantage most completely secured by the very democratic, and yet very conservative, device of the referendum. Democratic government may be less enlightened, less scientific, and in some ways more stupidly conservative than the government of an intelligent and benevolent monarch; but it has this enormous advantage, that its laws cannot permanently run counter to any very widespread public sentiment.

In the light of history it is easy enough to explain why Jefferson should have thought that government ought always to be an object of suspicion on the part of the people. The government of George III. had been to the patriotic Virginian an alien and hostile force. It is easy to understand why Kant and Von Humboldt and Fichte (in his earlier stages) should have formulated the principle that government has only to do with the maintenance of rights 
betwcen individuals. They had had a little too much experience of arbitrary royal edicts. If a philosopher is commanded by a foolish king not to lecture on certain subjects, he is not so likely to exalt the function of government as a philosopher who basks in the sunshine of the powers that be. It is unfortunately very easy to understand why serious-minded Russians should become anarchists. Every one knows the story of the Irishman landing at New York, and being asked what his politics were. "Is there a government in this counthry? Then I'm agin the government." The story is generally told to illustrate the political incapacity of Irishmen. I incline to think it throws a lurid light on the relations in the past between Irishmen and the English government. Governments may to some extent be judged by the nature of the opposition which they provoke.

If we go back to the political writers of the early part of the nineteenth century, we find "agin the government" a widely diffused sentiment. William Godwin considered law "an institution of the most pernicious tendency," and, though not much in sympathy with mediæval theology, he would quite have accepted the very usual mediæval opinion that government was the consequence of sin, and that those bold, bad men, Cain and Nimrod, were its founders. 
Professor Henry Sidgwick in his book on the Elements of Politics treats of the functions of government before he proceeds to treat of the structure of government; for, you must know what you want your government to do before you can settle what form your government should take. True, but is not the converse at least equally true ? You must know what the form of your government is before you can settle what things the government can wisely or safely undertake.

Mr. Herbert Spencer thinks that the divine right of parliaments has supplanted in many people's minds the divine right of kings, and that the former doctrine is every whit as absurd and mischievous as the latter. Well, it might be, if parliaments were entirely hereditary bodies; though even here there might be some safety for the people in the quarrels of the oligarchs. But if parliaments are largely or entirely representative bodies, they may be expected on the whole to be at least not more foolish than the mass of the people who elect them. Mr. Spencer seems to trust the wisdom of the average individual to regulate a great many difficult matters and to decide on affairs of vast importance affecting the welfare of other people; and yet he has no confidence in that same individual when he is giving his vote at the election of an M.P. He 
would trust his individual to decide for himself, without any State-sanctioned diploma to assist him, which among a number of competitive advertising quacks was the most competent physician to have the charge of his sick household. He would trust him to decide whether his children should learn to read and write or should spend all their youthful days toiling underground in the mines. He cannot trust him to decide whether $\mathrm{A}$ or $\mathrm{B}$ is more likely to look after his interests in the House of Commons for a limited number of years; for that is all that the divine right of parliament comes to. And yet $\mathrm{Mr}$. Spencer is a strong believer in voluntary cooperation; and his individual, as a shareholder in a joint-stock company, can be trusted to vote for the proper directors, although the shareholder is generally much more in the dark about the board of directors and their doings than the elector is about the doings of the House of Commons.

The American and the French Revolutions formulated two main political doctrines (I say "formulated," for they did not create them, but only gave them a conspicuous expression), the doctrine of natural rights and the doctrine of the sovereignty of the people. The former doctrine represents the negative part of the movement, the protest in favour of claims which the old regime 
had ignored. The latter doctrine is a positive doctrine, determining for the future the principle on which all constitutional government must rest. It is a principle not incompatible with monarchy, and was indeed recognized by the first monarch of the modern type, Frederick the Great of Prussia, when he said, "The King is the first servant of his people." Translated into more commonplace and more practical language, the sovereignty of the people means that, in the last resource, the structure and the functions of government must depend on the consent of the governed, or, we should rather say, on such consent of the governed as is compatible with social cohesion and the continued existence of the political society in question. For the liberum veto in the hands of every citizen would have the same ruinous effect on a democracy which it had on the aristocracy of Poland. The modern State in its idea (i.e., what modern constitutional States are tending to become) does not therefore differ absolutely in character from voluntary associations. The difference, important as it is, is a difference in degree. The interests with which the State is concerned are of a much wider and more permanent and more complex character than the interests with which any one voluntary association is concerned-unless the Church be considered an exception. But as 
regards practical freedom, the aggrieved individual is caught in the meshes of what are called voluntary relationships quite as much as he is caught in the meshes of that large and complex association which we call the State. Thus the average man is at least as completely at the mercy of the railway company, the water company, and the gas company which rule over his district as he would be at the mercy of the State, if railways, water, and gas were all under public authorities. A man may indeed refuse to wash, as a protest against the local water company, and by refusing to have his house supplied with their water he may avoid the waterrates. But, similarly, if a man abstain from beer, wine, spirits, and tobacco, armorial bearings, dogs, guns, legal documents, and stamped paper, he will evade a number of Imperial taxes. In either case he might or might not undergo inconvenience. In many ways it is quite as difficult for the ordinary man to escape from the control of "voluntary" associations as it is to escape from the control of the State. A physician, e.g., may quite as easily emigrate and voluntarily join a new State as offend against professional etiquette.

It is true that the State is able to back up its commands by the use of regulated force, whereas voluntary companies can only resort to civil actions- 
i.e., they have to fall back upon the State to enforce legal remedies. But suppose the State and its regulated force withdrawn, private persons and private associations would pretty soon be driven to resort to the direct use of force. Abolish the criminal law, and we should have an extensive system of lynching, in which "voluntary" would be practically swallowed up in compulsory co-operation.

Some of the strongest advocates of individualism have fully recognized the fallacy in a great many of the usual arguments against State action. Thus Mr. Wordsworth Donisthorpe, in the very clever essay which he contributes to that manifesto of conflicting individualisms called $A$ Plea for Liberty, admits that the tyranny of many so-called voluntary associations is quite as much to be dreaded as that of the State, that there is no ultimate difference in kind between the State and other associations, though they may be called only clubs, companies, societies, and the like, and that the State, at the worst, is only "the most aggressive club in existence" (p. 97). Lord Pembroke, again, in a pamphlet issued and circulated by the "Liberty and Property Defence League," points out that merely to collect all the mistakes and failures of legislators and government officials is a most illogical argument against State action, unless we were also to collect 
and pillory all the mistakes and failures of private enterprise. "Law," he says, "is nothing but public opinion organized and equipped with force, however grave the questions affecting such organization and equipment may be; and so far from law being always a worse thing than private action, the difference between them is in many cases simply the difference between civilization and barbarism" (Liberty and Socialism, p. 40). To this I should add, that one great advantage which the acts of public bodies, in a democratically organized state, have over the acts of private companies is the greater publicity with which they must be done. That is the very reason why the mistakes and failures of government are more easily detected and more frequently attacked than the mistakes and failures of private companies. But this facility of detection, this openness to criticism, is not altogether an objection to State management and State control.

When we talk of State interference, then, it makes a great difference whether the State is one in which the average citizen has any chance of getting his claims considered or not. It also makes a great difference whether the State is excessively centralized, or whether, along with a strong centralized government there is also a system of well-organized, responsible, and energetic local governments. The 
word "State" is apt to suggest the central government only; and a great many of the objections usually made to State interference are valid only against excessive centralization. This is particularly the case with the arguments employed by M. Paul Leroy-Beaulieu in his book on The Modern State -an ignoratio elenchi, unfortunately, excusable in a French writer. What matters should be taken in hand by the central government of a country and what matters by local authorities, and how far these local authorities should be under central control, these are important and difficult questions. No State, working on genuinely democratic principles, will attempt to regulate everything it undertakes from one or two central offices.

I have already admitted that the enforcement of the laws of a genuine and honestly worked democracy must mean the enforcement of the will of the majority against the will of the minority. We accept this, not as an ideal state of affairs, but as, on the whole and in most cases, a less evil than the enforcement of the will of the minority against the will of the majority, unless indeed the minority were always the perfectly wise and good, which is not likely to happen, and unless a majority excluded from power consciously recognized them to be such, which is also not likely to happen. But 
what then, it may be said, becomes of the rights of the minority? The most important right of a minority is (as I have tried to show elsewhere ${ }^{1}$ ) the right to turn itself into a majority if it can. That means a great deal; it means the right of free expression of opinion and the freedom of association. But these are rights which can only be secured to the individual by a strong and enlightened government which will protect him against violence arising from the intolerance and the prejudices of his neighbours.

\section{II.}

This, however, brings me to my next head, the word "interference." We cannot say whether interference is a good thing or a bad thing, until we know who or what is being interfered with. The policeman who stops the traffic in a crowded thoroughfare to let an old lady and her dog cross over is interfering with a great many people, but on the whole we regard such interference as beneficial. The Education Acts interfere with a great many people,-they would be no good if they did not;

'Article on "The Rights of Minorities" in International Journal of Ethics for January, I89I, republished in Darwin and Hegel, etc. 
but they interfere with the selfishness or the ignorance or the apathy of parents and employers of labour in order to secure to the children a paltry minimum of education. The Russian Government fixes a maximum for the education of the peasantry : beyond that it is a penal offence to teach a peasant. Both these kinds of Education Acts are "interferences" with the liberty of individuals. But there is a difference between them more important than the resemblance. The one is interference with the chance of the intellectual emancipation of the mass of the people; the other is a slight aid towards that emancipation.

Individualists-those who call themselves suchare curiously apt to forget the existence of families. The individual can only have a chance of developing the capacities he has, if law and public opinion put some pressure on the "natural groups" to which he belongs. Abolish the State and we should have, not individualism, but, after a period of anarchy, the patriarchal stage or some other "natural" grouping of a more rudimentary kind. Society would begin over again from its lowest elements; and only with the rise of the State could it escape from savagery and barbarism. Again the pressure of public opinion, as we have just seen, may need control on the part of the State in order to protect 
individual liberty-above all the liberty of thinking, writing, and speaking, which is the only ultimate security for social progress, and therefore the most precious of all liberties. Only in a strong State is individual freedom really possible, individual freedom which is a reality and not an empty form.

People who pride themselves on their judicial habit of mind often incline to take what seems to them a safe and middle course. "A little State action is a very good thing," they say, "a little State socialism even; but you must not have too much of it. You must throw in a good deal of individualism as well." Now this "half-and-half" doctrine-a little of the one and a little of the other -only reveals the inexactness of thought of those who maintain it. It is nonsense, unless it merely means that it would be very unwise to try to do everything at once, and that in practical matters we must proceed by a method of compromise. There is no necessary or absolute antithesis between State action and individual liberty, unless indeed by "individual liberty" were meant simply "absence of State action," in which case the most miserable of savages, or the most wretched of factory-children before the Factory Acts, would be the models of "free" human beings. All salutary State action must be such as will give individuals so far as 
possible the opportunity of realizing their physical, intellectual, and moral capacities. In a genuine and honestly worked democratic State, State action and individual liberty will no longer be opposing principles, as they are under despotism tempered by partial anarchy; individual liberty will exist, not in spite of, but by means of State action.

When we have defined the end of State action as the realization of individual capacities, it may well be objected that such a principle, however true, does not help one much in practice; it is too vague. We want some clear and precise principle which will definitely mark off beforehand what things the State ought and what it ought not to undertake. I am afraid, however, that no such definite $a$ priori principle can be found. Individualists would probably accept the principle of "equal liberty" as the limit of the individual's right to do as he likes. "The formula of justice," according to Mr. Herbert Spencer, is this: "Every man is free to do that which he wills, provided he infringes not the equal freedom of any other man." Now if no man may ever justly do what interferes with the equal liberty of any other man, this seems to me to bring us to a deadlock. The principle of equal liberty, if strictly taken, means an equally complete absence of liberty. I cannot occupy this spot of earth, on 
which at this moment I am standing, without interfering with the equal liberty of every one else to occupy this same spot at this same moment. Equal liberty cannot, then, mean liberty to do the identically same act: let us take it as meaning liberty to do similar acts. How is a public meeting to be justly regulated on Spencerian principles? No one has liberty to stand up and speak in his place, unless every one else may stand up and speak in his place at the same time. It would be very awkward to be chairman of that meeting, even if any one was allowed to be chairman without every one else being chairman also. Of course, it will be answered, the principle does not mean anything so absurd: it only means that it is not fair that some persons should get privileges (e.g., of speaking at a meeting) which are not open to all others, even though they may not avail themselves of them. Well, it is true, that is the principle of an open meeting and free debate; but the opportunity of speaking is surely not an absolute and inherent right of every man? It is dependent, in practice, on the willingness of the meeting to listen to him. The intolerable bore has no natural and indefeasible right to be listened to with patience. The opportunity of speaking is dependent on the existence of the belief that there is some desirableness, some 
gain for the society as a whole, in hearing what people have to say. This "equal liberty," therefore, if in any subordinate sense it is recognized, is not an absolute and primary, but a derivative principle, dependent on some idea of common good or advantage. ${ }^{1}$

Locke, in his Treatise on Civil Government, applies the principle of equal liberty to defend the right of property as based on first occupation. Every one has a right to the land, etc., which he occupies, provided that as good is left for others. But very likely none as good is left for others; and, in any case, this equal goodness (which must include convenience of situation as well as excellence of quality) will very soon tend to disappear. As a matter of fact, the newcomer, as a rule, puts up with the best he can get rather than risk the opposition which he would meet with if he appealed to the law of equal liberty. That is to say, everywhere rights are dependent not on any abstract a priori principle, but on the agreement, explicit or implicit, of a society.

The French "Declaration of the Rights of Man" of I79I (drawn up in '89) formulates the principle in a much more cautious manner than Mr. Spencer:

${ }^{1}$ I have discussed this principle of "equal liberty" more fully in my book on Natural Rights. 
"Liberty consists in the power of doing whatever does not injure another. The exercise of the natural rights of every man has no other limits than those which are necessary to secure to every other man the free exercise of the same rights; and these limits are determined only by the law."

Here, in the first place, the consideration of injury to others is brought in over and above the mere abstract principle of equal liberty. Secondly (and this is even more important) the determination of the limits of the exercise of "natural rights" is left to the law; so that the principle of equal liberty is no longer something standing outside of and above the action of the legislature.

Another formula which has very often found acceptance as determining the end and the limits of government action is the principle of giving every one "an equal start." Open competition will, then, it is argued, lead to "the survival of the fittest." Yes, if all start fair. But that would involve a very extensive amount of government interference nowadays, when the characters and circumstances of individuals have been moulded by unequal legislation in the past. We should have to prohibit inheritance of property, we should have to secure an equal education for all, equally good housing and feeding, etc., if the race of life is really 
to determine who is the best man. It is only a mockery to take an untrained man, with clumsy boots on his feet, and a trained athlete in proper costume, and set them to run a race, telling them it is quite fair, because they have an equal start. If the demand for an equal start be pressed, every man might claim the right to be well born; and that would involve a pretty extensive interference with individual liberty in the matter of marriagean interference with the relation of the sexes which no individualists and (as yet) few socialists have been willing to contemplate.

We are driven back, then, on "Utilitarian" considerations; only, instead of the somewhat arithmetical formula of "the Greatest Happiness of the Greatest Number," it may be safer to substitute the vaguer principle of "the common good"-that being understood to mean the highest development of individual capacities compatible with the coherence and continuance of the society as a whole. I say "continuance" because we must take into account the future as well as the present. This being the end in view, we must at each point ask ourselves three questions:

(I) Does the end proposed by some particular measure lead towards our ultimate end or not?

(2) If it does-i.e., if the end of this particular 
measure is good-are the proposed means such as will really secure that end?

(3) If we consider that they will, we have still to ask ourselves whether they will do so at too great a cost or not. We must ask: Will the advantages arising from the means outweigh the disadvantages, advantages and disadvantages being judged solely by reference to the ultimate end, the common good, as defined above?

If a measure satisfies all these conditions, it is pedantry or prejudice to object to it, because it violates some abstract principle of individual liberty or some a priori doctrine of natural rights.

State interference suggests to many minds an inquisitorial system fatal to all intellectual and moral progress; and, as I have shown, State interference may mean that, and has often meant that. But because two kinds of legislation may both be classed under the general abstract head of State interference, it is very absurd to refuse to recognize the differences which may exist between them. For the purpose of illustration I shall take two cases on which, I think, I may assume that we are mostly agreed.

Why do we approve of the Education Acts? (I) That our fellow-citizens should be educated as far as possible, that they should at least not be grossly illiterate and ignorant, seems to us all, I 
shall assume, a desirable end; it is an important element in and means towards the common welfare. (2) Well, then, will compulsion enforced by attendance-officers and backed up by legal penalties secure that end? To some extent it has failed; but to a great extent, in this and other countries, it has succeeded. (3) Does the enforcement of compulsion bring with it such great attendant evils as entirely outweigh the advantages of it? I think most persons would admit that it does not. Some evils there are undoubtedly; but so there are in every arrangement among human beings, and-what is apt to be forgotten-in every want of arrangement. Therefore we conclude that compulsory education is desirable.

But because we think so, are we in consistency bound to think a censorship of the press desirable also-a censorship, I mean, as a permanent institution in a settled country in time of peace? (I) The absence of mischievous and immoral literature would, I fancy, be generally admitted to be a desirable object. But then, unfortunately (or rather fortunately for the world's progress), opinions differ greatly as to what is mischievous and even as to what is immoral. No one professedly admires immoral literature, at least in public; but one person may tolerate, or admire, or even commend as highly moral what 
others think immoral. This diversity of opinion is an important factor in our question; because of it, we are a little doubtful of the expediency of the end at which a censorship of the press aims-the maintenance of a common and uniform standard of opinion as to morality. (2) We should be still more doubtful about the means of attaining that end-the arbitrary power which must be entrusted to a government official who cannot be expected to be a perfectly competent and fair-minded critic in every department of literature. (3) And, above all, we should consider the risk of interference or possible interference with good and useful literature too great to be safely run, and the suppression of the liberty of the press certain to be accompanied by the evils of a contraband traffic in literature of the vilest kind. Special danger is always likely to arise from the closing of a safety-valve.

I only give these examples as roughly indicated specimens of the way in which we must think out the arguments for and against any measure of State interference. What I am anxious to urge is, that there is no a priori presumption for or against State interference. We must consider every measure solely from the point of view of the probable effect of it on the welfare of the community as a whole, now and in the future. 


\section{IV.}

\section{CIVIC DUTIES AND PARTY POLITICS. ${ }^{1}$}

THERE is one sense of the phrase "civic duties" 1 on which I need not say much, and that is its strictly legal sense. The citizen is bound to obey the laws of the land so far as they concern him-to pay his rates and taxes, to abstain from crimes against person and property: if he disobeys, he is liable to punishment. We should not, however, consider a person to be a model citizen simply because he had not been taken up by the police and convicted in a court of justice. Civic duty in the moral sense means something more than the negative merit of not doing any of those acts which at a particular time and in a particular place are prohibited by law, something more than fulfilling those active duties which are made compulsory by law. There are even extreme cases, though in any fairly well-ordered and constitutionally governed society

1 This paper appeared under the title "Civic Duties" in the Co-Operative Wholesale Societies' Annual for I8g8. 
such cases should become more and more exceptional, in which a conscientious citizen may feel himself morally obliged to violate existing laws and to bear the brand of the criminal in his own generation, in order that those who come after him may live under what he conceives to be better laws. In any case the good citizen is something more than the merely law-abiding person. His citizenship is of a more active kind. He recognizes duties towards his fellow-men and strives to fulfil them, although no penalty of fine or imprisonment be attached to their neglect.

There are, indeed, many moral duties that go far beyond what is in any country legally enforced - duties which in a wide sense of the term might be called civic duties, because the fulfilment of them makes good citizens and the neglect of them is sure to make bad citizens. I mean such duties as those of trying to do, to the best of our ability and without "scamping," any work that we undertake, of dealing honestly with one another in trade and business, and all the duties created by family ties and by the links of neighbourhood and association. But such duties would generally be classed as "industrial" and "social" duties, the name "civic duties" being conveniently reserved for those which concern us not as employers or employed, as buyers 
and sellers; not as husbands or wives, parents or children; not as neighbours and friends, or as members of the same private association; but for those duties which concern us as members of a society which has a government in the strict sense. Aristotle defined man as a political animal. $\mathrm{He}$ meant exactly what he said-not merely that man is a social animal, needing and craving to live in groups "more even than the bees," but that man could not realize the full possibilities of his nature, unless he lived in a society which had a constitutional government in which he could have some share. Knowing nothing of representative institutions (which are truly one of the greatest "inventions" of mankind), Aristotle thought that such a condition of life could only be attained in a small city state (the Greek word polis, from which comes our word "political," means at once "city" and "state")-a small city-republic in which all the citizens (i.e., all the adult male persons, not being aliens or slaves) could meet together in the marketplace and settle their affairs and elect their magistrates. The political society which he thinks of is such as exists at the present day only in some of the smaller Swiss cantons, such as Uri and Appenzell, the most democratic and at the same time, perhaps, the most conservative communities 
in the world. But the spirit of what Aristotle says is perfectly applicable to modern conditions in a large nation. "Man is by nature a political animal." Different people seem, indeed, to show more or less capacity for using and working political institutions. They are "political animals" in varying degrees. But the meaning of the saying is that, if cut off from the life of active citizenship in a constitutional state, human nature fails to attain fully the best things of which it is capable; so that those who live under a despotic government, which refuses to them any rights of active citizenship, and those who, living under a constitutional government, abstain from exercising those political rights which they have, both fall short of the full realization of their natural capacities.

Now, in this country men are, as a rule, "political animals" as much as anywhere else, and more so than in most countries. We are, fortunately, not in the habit of attaching a bad meaning to the word "politician," like so many of our kinsmen in the United States of America. Still, there are a good many people among us whose interest in politics, except, perhaps, during the passing excitement of a general election, is faint and languid, who, when they take up a newspaper, will read through the "sporting intelligence," or the latest 
reports of crimes and accidents, before they turn to the Parliamentary debates or to the scraps of information which the papers give about the Colonies and foreign countries. And when such people come across those less interesting parts of their journal they may say, in the words, if not exactly in the spirit, of the National Anthem, "Confound their politics." And some of these persons may ascribe their absence of political interest to their having a greater interest in human affairs that come nearer to their own habitual pursuits and amusements, and may maintain that very little good comes out of all that can be done by government, so that all the talk and fuss about political matters is but "vanity and a striving after wind"; while there are some who will insist on the difference between politics and morality, or the difference between politics and religion, and who will argue that the really serious-minded person does right to leave politics to the politicians. Thus, politics are thrust aside by some as being too dull, and by others as being too frivolous. And there are a few who call themselves "Anarchists," and will denounce the State and all its works, all its machinery of parliaments and elections, taxes and law courts, as a foolish and wicked interference with the natural liberty of man. 
The Russian, Tolstoi, whom every one who has read him admires as a writer, and whom we can all respect as a man, has in this country some few followers even in his hostility to everything of the nature of government. He hates government, and regards it as an irreligious institution because it employs force. Now, it is only too easy to understand how a serious and thoughtful man, living under the dark shadow of Russian despotism, seeing before him a government in many ways oppressive and in many ways corrupt, should come to look upon all government as an abomination. But when we find such ideas adopted in a Western nation, whose constitution and laws are, in the last resort, in the hands of the citizens themselves, we cannot but think that the adoption of such a despairing Anarchist creed means some neglect of civic duty. If you are dissatisfied with much in existing institutions, you are in this country at liberty to preach your views and to agitate by peaceable and orderly means. If your ideas are such as are really fitted for mankind, such as human beings could adopt and practise without sinking into confusion or savagery, if they are such as would mean an improvement and not a deterioration in the conditions of life, you must surely hope to be able to convert other people to them 
and thus gradually to get institutions moulded to your ideal. If you have no such hope, or if, because everything cannot be put right in your own lifetime, you regard the hope as too distant to be worth cherishing, you certainly should not expect sympathy from the mass of your fellow-citizens in your impatient demand for the ovcrthrow of institutions which others still hold to be of some value, or in your sullen withdrawal from the attempt to make the best use you can of the imperfect constitutional means at your disposal.

Those who are dissatisfied with the best of civilized governments may be recommended to put themselves back in imagination-and this they can easily do with the help of impartial historians-in some place or period when government was very weak and "every one did that which was right in his own eyes." We are so familiar with the orderly and not altogether intolerable system of government under which we have grown up, that we are apt not to see how much we owe to it. Those who think that everything can be done by voluntary associations forget how it is under the shelter of the "compulsory association," which we call "the State," that our voluntary associations have been able to develop. Voluntary associations can dispense with the use of force, just because they 
have the force of the State behind them. Why can we walk about without swords at our sides or revolvers in our pockets? Why is the labourer and his family in a lonely cottage on the moor safer against attack than the great baron of the middle ages in his grim castle? We may think the police system capable of improvement; but, before we denounce it altogether, we should study something of the condition of the country before there was any regular police system at all, and when the only means of obtaining a precarious security was by paying blackmail to some powerful brigand, some Robin Hood or Rob Roy, so that he might plunder other people and spare us. Why is it that we can put money in a bank instead of having to hide it underground? How does a voluntary association obtain payment of debts or retain possession of its buildings and stock? How is it that we can import tea and coffee, cotton and flax, without fear of pirates on the high seas?

If there were no State, with navy and army, with police and magistrates, we should be driven to form voluntary associations to supply in an irregular way the want of that regulated force by which the State, more or less effectively, secures peace and order. Our governments have actually grown up, to a great extent, out of voluntary 
associations. The feudal system, out of which the nations of modern Europe have gradually developed themselves, was in its principle a voluntary association by which men put themselves under the authority of a superior in order to be protected against violence from without. Our municipal governments have been developed out of the tradeguilds of the middle ages. The line between voluntary and compulsory associations cannot be drawn so abruptly as Mr. Herbert Spencer and his followers think. The State, in a country where the citizen has some say in its administration, is simply a very large (perhaps not always very economically or very skilfully managed) co-operative society, of which most people become members by birth, and which is able to use directly that regulated force which other lawful societies can use indirectly through it. When we pay our rates and taxes we are paying our contribution to the up-keep of this great society; and even if we do not always and in every respect approve of the way in which the income of the country is spent, we should probably find that, if we had to defend our houses and warehouses, our goods and our travellers by land and sea, the expenditure on private police and on powder and shot would prove more irksome than even the payment of rates and taxes-with this 
additional drawback, that rival towns and rival factories might be too readily tempted to use their powder and shot against one another; and this would be a more wasteful form of competition even than that which exists at present. If we look at the State in this way as the great association of which we are all members, it is surely our interest to concern ourselves in its affairs; and, as the wellbeing of ourselves and our families is affected by good or bad government, it is not only our interest but our duty to do so.

We must not exaggerate. A great part-in some ways the more important part-of human life lies outside the region that the State can directly affect. "You cannot make a man moral by Act of Parliament." In one sense that is a truism. Conduct is only morally right if it is done from right motives, and external compulsion can only affect the outward actions (though that may be a great benefit to society); but the man who abstains from wrongdoing merely through fear of punishment is very imperfectly moralized. Governments in times past have often tried to make men religious, after this or that particular pattern of religion, and have succeeded in making martyrs and-hypocrites. "Government cannot make one shoeblack happy." True! Happiness depends a great deal on inherited 
temperament and on the state of the liver. But while these minimizings of the power of government are true, they are not the whole truth. The State cannot directly make any one individual happy, or wise, or good; but the character of the institutions under which he lives will make a great deal of difference to him in his endeavours to escape misery and to make the best of his natural endowments. The State can affect the conditions under which we have to live our lives; and so, though not directly, yet indirectly, political institutions influence the physical, moral, and intellectual well-being of individuals and families. A great deal of the controversy about the proper nature and functions of government is apt to be futile, because the disputants ignore this important distinction between what can be done directly and what can be done indirectly. Those who see clearly that the State can do very little directly to make any one happier or better think politics may safely be left alone; for

"How small, of all that human hearts endure, That part which laws or kings can cause or cure!

Still to ourselves in every place consigned, Our own felicity we make or find." 1

On the other hand, those who see clearly the

1 These often-quoted lines are in Goldsmith's Traveller, but were written by Johnson, 
importance of the conditions under which people have to live, and the extent to which laws and institutions can affect these conditions, are apt to expect "the millennium by Act of Parliament," and to disparage unduly what must be done, and can only be done by individual effort and by voluntary association of those who are personally keen about what they are striving for.

At certain times the objection to meddling in politics has been specially associated with an intense religious conviction of the unimportance of everything external, and a disparagement of all that belongs to "this world." Under the despotism of the Roman Empire, with the confident expectation that the end of the world was at hand, or in the enervating climate and social torpor of the tropical East, such a turning away from the vanity of political things is sufficiently explicable. But in the more bracing physical and social atmosphere of Northern and Western countries all the more healthy and vigorous forms of religion prove compatible with the life of the active and useful citizen, and more and more the conviction is growing in the churches themselves that there is a lesson in the "parable of the talents" that has not always been fully learnt or taught. He who withdraws from this world to prepare for another is, unless under exceptional 
conditions, wrapping his talent in a napkin; while he who "treads the prosaic path" of the good citizen is putting out his talent to interest.

While admitting, with all due moderation of statement, the importance of good government and the consequent importance of taking an interest in politics, many people may still object that they cannot hope to do any good or affect the government of their country in any way because politics has become entirely an affair of party. Politics, it is complained with much show of justification, has become a sort of game, a national sport, like cricket, in which first one side and then the other have their innings, longer or shorter according to the better batting of the side that is in or the better bowling and fielding of the side that is out. The party system seems to many people essentially immoral as well as foolish; it introduces the excitement of a sport into the serious business of managing the affairs of the country, and it leads people to vote contrary to their real convictions on many subjects because they are keenly interested in some one or two articles in the political programme of a party which bids for their support.

It is as well to admit at once that the existence of parties, and still more the system of party government, contain elements of evil. It has always 
been the aspiration of social reformers to get rid of party. But we have to face the facts, and a study of history and a comparative study of presentday politics in different countries show us that there is a greater evil than the existence of parties, and that is the complete absence of them in any society which has yet existed among mankind-a greater evil than our system of party government, and that is the instability which may come from the conditions being unfavourable to the working of it. Party means association, and the man who can never work along with any group of his countrymen, or who can never get any others to work along with him, must have something odd in his disposition, something which unfits him for influencing his fellow-citizens in any direct way. To get an idea realized in politics, the person who believes in the value of that idea must induce others to think with him. Under an absolute monarchy his only resource is to seek to persuade the monarch, or some court favourite who can persuade the monarch, of the advisability of what he wishes done. Under a more or less democratic constitution, a constitution which places legislative power in the hands of a considerable number of persons, his only resource is to form a party for the carrying out of his idea, or to persuade some existing party to take up 
this idea into its programme. True, it may be said, (I) but why should there be more or less fixed and permanent parties? Why should not people group themselves in different ways for different purposes, acting sometimes in one combination and sometimes in another? (2) Why, above all, should we have had in this country two, and only two, great parties struggling for possession of power?

The answer to the first of these questions is to be found in certain facts of human nature; the answer to the second in the historical conditions of our political development. Those who act together for some one purpose, that requires time and skill and patience to carry it out, acquire a habit of acting together in many matters, and the germ at least of a party is formed. Quickly shifting, temporary combinations can never have the same effective force even for one single purpose. A regiment of veterans, who have passed years together and have stood shoulder to shoulder in many hard contests, is a much more powerful fighting-machine than a more numerous body brought together only for one purpose. A political party, for the same reason, can effect more than associations for single purposes. Of course, associations that exist primarily for other than political purposes (e.g., churches, trade unions, etc.) can exercise great power in 
politics when they choose, but chiefly by throwing the weight of their numbers and their influence into the scales of one or other of the contending political parties.

Our unwritten British Constitution, as it now actually exists, is dependent for its smooth working on the existence of two, and only two, great parties. The distinctive feature of our system is the Cabinet -i.e., a body of Ministers who are at the same time members of the Legislature, who are bound to act together on all matters that are considered important by their leaders, and who are dependent for their authority on the support of a majority in the House of Commons, and are expected all to resign their offices together when they cease to have that support. A set of Ministers, however able and patriotic, whose political views differed on prominent questions, could never obtain the power which the British Cabinet exercises in legislation as well as in administration. Hence the working of the system tends to induce the Ministers to sink differences of opinion and to act together, as far as possible, and perhaps rather further than might seem possible to those who judge them from without. There is an oft-told tale about Lord Melbourne (who was Prime Minister in the early years of Queen Victoria's reign); it may or may not be quite false, 
but it puts, in a striking though somewhat cynical way, the necessity for a Ministry working together. A Cabinet meeting had agreed to propose a fixed duty on corn. When the Ministers were rising to go, Lord Melbourne put his back to the door and said: "Now, is it to lower the price of corn, or is it not? It doesn't much matter which we say, but, mind, we must all say the same." 1

Party cohesion is absolutely necessary in a Cabinet. The Minister who cannot bring himself to agree with his colleagues must resign and give place to one who can. But party cohesion is also necessary in the House of Commons. A Cabinet which no longer has the support of a majority-a Cabinet which is defeated on any one important issueresigns. Hence those who support it because of their interest in any one question have an extremely strong inducement to support it upon all questions, even upon those on which they are lukewarm, or in their inmost hearts hostile. When a Ministry resigns, a new Ministry is formed, which must in its turn have the support of a majority in the House, if it is to remain in office and do anything. The cohesion of the Opposition is thus as much a

1 Walter Bagehot, The English Constitution (edit. 1872), pp. I4-I5, note. 
necessity of the smooth working of our system of Cabinet government as the cohesion of the party in power. The Opposition have the strongest inducement to stick together, not merely to such an extent as to overthrow a Government : a temporary combination of extremely antagonistic factions may be able to do that; the Opposition must have such an amount of cohesion that, after overturning the party in power, they can support a Ministry formed out of themselves. If the new Ministry cannot find sufficient support among those whose voting has displaced its predecessors, this new Ministry will resign, and the old Ministry, with its more coherent body of followers, will take office again. The struggle for political preponderance insures the survival of those who are the stronger party men. The existence of a regular Opposition is necessary to the cohesion of the party in power; the knowledge that, if they defeat the party in power, they must be able to take their place makes cohesion necessary to the Opposition, and is at the same time a great check upon their conduct. The irresponsible critic, or those in a hopeless minority, will say and do things which those who may shortly find themselves in office will not venture to say or to do.

I am not attempting to represent the system as an ideal one. I am simply putting together various 
familiar characteristics of our system of party government in order to describe correctly the actual machinery of our Constitution, as that has come to be after the struggles and the progress of centuries. It is that political machinery which has been the envy of foreign countries, and which all the newer Constitutions of the modern world have tried to imitate, more or less successfully. It is very easy to condemn and to ridicule the system of government by means of two parties. General fault-finding is an easy, business. It is not so easy to show how the advantages can be kept, or obtained, without this system of two great parties and only two.

Of those Constitutions which may be regarded as Constitutions of the same type as our own-I mean Constitutions that have the Cabinet system in the British sense-the one which has on the whole worked most smoothly is the Belgian. That is just because in Belgium there have been-at least until lately - two, and only two, great parties, the Liberal and the Clerical, nearly equally matched, and each ready to take the place of the other in office. Italy, whose Constitution in many respects very closely resembles the British, suffers from the lack of a real Opposition. The Pope has not yet forgiven the Italian Government for putting an end to his 
temporal rule in Rome, and all those who follow the instructions of the Vatican abstain from taking part in Italian politics. Thus, in the Italian Parliament the members are almost all really of one party -all "Liberals," more or less. They have no strong Clericalist opposition, like the Belgian Liberals, to make them keep together; consequently, they have come to be split up into numerous small groups, bound together by merely personal or local ties. In France-and the present French Constitution, having our Cabinet system, much more closely resembles the British Constitution than that of the United States, in which the Ministers, though called a "Cabinet," are independent of the support of the Legislature-in France we find instability arising from precisely the opposite reason from that which causes it in Italy. The great difficulty in France has hitherto been that there are so many parties widely separated from each other in their views, and some of them actively hostile to the Republican Constitution itself. There are not merely parties within the Constitution, as with us, but parties for and parties against the Constitution. The result is that temporary combinations are easily formed between extreme groupse.g., between Monarchists and Socialists-against the more moderate sections of Republicans-combinations which can sometimes overthrow Governments 
or render them unstable, but which do not serve the constitutional function of a regular Opposition, because they are too much disunited among themselves to be able to form or support a Government of their own. In Germany, constitutional and parliamentary government is, as yet, in a much more rudimentary stage than in these other countries. One reason for that is the great power which the German Emperor possesses as King of Prussia. The German Emperor, with his Chancellor, whom he appoints himself, is, in fact, such a King as Charles I. wished to be in England, rather than a constitutional chief of the executive, such as the King in Britain, Italy, Belgium, or the President of the French Republic. But the Emperor keeps his power (or his Chancellor does, if he be the stronger man, as Bismarck was while in office) very largely because the Imperial Parliament (the "Reichstag") is split up into so many different parties, or rather groups. *. There are 397 members in it, and there are at least fifteen parties. The largest-the Roman Catholic party, called the "Centre"- has only 96 members; next come the "German Conservatives" with 72; the "National Liberals" with 53; the "Social Democrats" with 44. There is a group of four "Independents," and there is one party, a patriotic Danish party, which ought to be a very coherent 
and solid party, for it consists of one member. ${ }^{1}$ Now, in such a divided Parliament our system of responsible Cabinet government would be impossible. A clever despot, such as Prince Bismarck undoubtedly was, can always manage to play off some of the groups against the others, and secure his own way; and even the present Emperor, who is not perhaps so clever as Bismarck, gets a great deal more of his own way than he would if the German politician showed more habit of pulling in party harness.

Our system of Cabinet government-i.e., of Ministries responsible to the elected part of the Legislature-requires for its smooth working the existence of two, but only two, great parties. It inust not, howcver, be supposed that, under other systems of government, parties disappear or that the citizen can necessarily cscape the difficulty of choosing between two parties. If we turn to the Constitution of the United States of America-in almost every respect the most instructive contrast to our British Constitution-we find that, although our system of Ministries responsible to the Legislature has been expressly prevented, the evils of party are in some

1 These figures relating to the Reichstag are taken from Mr. A. Lawrence Lowell's Governments and Parties in Continental Europe $(18 ; 6)$, Vol. II., p. 42 . It is in every respect an admirable work. 
ways far greater than among ourselves. Indeed, for those who are strongly impressed by the evils of party, one of the most disappointing things in the political world is the actual working of the Constitution of the United States. That Constitution was intended by the wise and careful men who planned it to work without party divisions. The President nominates his own Ministers, and the Ministers are not dependent on the continued support of a majority in either House of Congress. The President and his Ministers were intended to be above and independent of party; they have come to be entirely the creatures of one or other of the great party machines. One cause of the excessive influence of parties in American politics has undoubtedly been the practice of making Civil Service appointments on the evil system expressed in the words, "To the victors belong the spoils." A Civil Service dependent upon party success is a corrupting influence in public life, and has contributed more than anything else to the degradation of the name "politician" in America.

I have referred here to the United States, only to show that our British system of government is not responsible for the evils, such as they are, which follow from the existence of two great permanent political parties. The facts I have noted in European 
countries which have imitated our system are a proof that the existence of two great permanent political parties is a safeguard against still greater evils; and they are well worth pondering by those who can see only the dark side of our political life, and who lightly set about the formation of new and independent groups.

In giving his vote at an election a man may wish to keep himself as independent of party as possible; he may say he is simply voting for the best man, or that he is simply voting for some particular measure in which he is interested, and which one candidate has promised to support. He cannot help voting for or against one of the two great parties which in turn control our administration. No voter in this country at present can escape the responsibility of helping to put one or other of two rival leaders into office. There may thus arise for the thoughtful citizen, at election times, various difficult questions of casuistry. It may often happen that he cannot choose between one candidate whose programme he entirely accepts and one to whose policy he is entirely opposed; his choice may have to be determined by much more complicated considerations of comparative agreement and disagreement. Yet it is one of the duties that devolves on every elector to exercise this choice. To make the difficulty of 
deciding an excuse for staying away is to shirk a public duty, and perhaps to leave too much power in the hands of voters who never have any conscientious scruples about the use of their votes. A great deal might be said in favour of making voting at elections-parliamentary and local-a compulsory duty of the citizen-like serving on a jury when summoned. This is actually the case in the new Belgian Constitution of $1893 .{ }^{1}$ In some of the Swiss cantons a finc is imposed on those who neglect to vote. $^{2}$ In the seventeenth and eighteenth centuries we find this principle adopted in some of the American colonies. Thus, in Virginia any freeman absent from an election without lawful cause was fined one hundred pounds of tobacco ${ }^{3}$ - the staple commodity of the place. It is not that the vote given by the citizen who went unwillingly to the poll would necessarily be of special value to his country, -and, after all, the obstinate anti-politician might insist on spoiling his ballot paper,-but such an enactment accentuates the principle that the suffrage is a public duty laid upon the citizen, and not a

1 Article 48.

2 Lowell, Governments and Parties in Coninental Europe, Vol. II., p. 273.

3 C. F. Bishop, Itistory of Elections in the American Colonics, p. 191. 
personal privilege which he may or may not exercise at his own good pleasure. Of course, if a man really cannot make up his mind how to vote, he is justified in abstaining ; but to be completely justified he must have made some effort to discover what the questions at issue are, and not abstain simply from laziness.

When the subject of party is studied in the way that I have briefly indicated, a good deal of the difficulty in it disappears. We accept the party system not as something good in itself, but as a less evil than we might otherwise have under the circumstances. We can recognize that the existence of opposing parties is not the degradation of politics to a game, but ensures to our government a stability which it might not otherwise possess ; and that, just as in a law court it is in the interests of justice that both sides should have their cases stated as powerfully and effectively as possible, although our sympathies may be all on one side or on neither, so in politics there is an advantage to the community as a whole in having both sides of every public question discussed by keenly interested advocates, in having every measure which a Government introduces exposed to a severe criticism by a party whose business it is to look out for faults, but whose fault-finding is tempered by the responsibility that comes from the possibility of being itself placed in 
power. No party is likely to possess a monopoly of wisdom and virtue, and it is therefore an advantage to us that our opponents should have as much of them as possible. They will be more useful as critics, and, if they turn out our side, the country will suffer less. As mere party men, we might, indeed, wish to think our opponents foolish, and even wicked; as good citizens we should wish them to be as wise and as virtuous as they can be-whilst differing from ourselves. Such a way of looking at party government may help to make us more ready to submit to be party men in moderation, and at the same time may make us more tolerant of those who do not agree with us.

Nevertheless, when all has been said that can be said on behalf of the party system of government, candour obliges one to admit that it has very serious defects. It is a better system of government than many others; but better systems than it are, at least, conceivable. It must be recognized, moreover, than even in this country, where the party system has worked better than in any other, there are indications which suggest that it may very likely break down in the near future. There is a greater impatience, among the mass of the voters, of strict party ties. There is a growing tendency to the formation of independent groups, the effect of which 
must inevitably be to render Governments brief and unstable, as in France and Italy, or else to place power permanently in the hands of one party (the strongest and most coherent) to the exclusion of all the others. In either case the advantages of our traditional system would have disappeared.

There is in many quarters an increasing demand for the "second ballot." It is a demand for which excellent abstract reasons can be given. Suppose that out of 2,000 votes A. receives 800, B. 700 , and C. 500, is it not rather absurd that-as in this country at present-A. should at once be elected, when, on a second ballot between $A$. and B. alone, B. might receive 1,200 or 1,100 votes? The introduction of the second ballot would, however, undoubtedly increase the tendency to form independent groups-a tendency which is mainly kept in check by the desire of the average voter to be represented by a candidate who is prepared to some extent to support some of the measures in which he is specially interested, if he cannot hope to carry a candidate with whom he is entirely in sympathy. The habit of compromisethe conviction that "half a loaf is better than no bread"-has hitherto prevailed among most of our electors. "Second ballot" would rapidly accelerate the break up of the dual party system of government. 
All this may seem a digression from my real subject. But the point I am endeavouring to bring out is that the duty of the citizen as a conscientious elector must be relative to the actual working constitution of the country he is living in. If anyone were to say, "I vote according to my conscience for the candidate I personally approve of, and I entirely disregard the political consequences of what I do," he would simply be showing that, however honest he might be in his intention, he had not taken the trouble to understand what his voting meant. An elector is bound to consider the political consequences of his vote. $\mathrm{He}$ is responsible to his country for all that his vote means. I do not wish unduly to exalt the duty of choosing between one or other of only two parties. "Our country, right or wrong," is not an altogether perfect maxim; but "Our party, right or wrong," is an abominable one. I simply wish to point out that the citizen who acts against that one of the two parties capable of taking office with which on the whole he has greater sympathy-either directly by voting for the opposite party or indirectly by voting for some independent party-must do so with his eyes open and with a full sense of the responsibility of what he is doing. The Americans have borrowed from an extinct Red Indian language an ugly word to 
denote the elector who breaks off from party ties; they call him a "Mugwump." The word originally meant "a mighty chief." The mugwump, as an independent voter, takes a great deal of responsibility upon himself. And what I wish to urge, put shortly, is only this, that mugwumpery may sometimes be a voter's duty; but it is a serious business, like marriage, not to be unadvisedly or lightly taken in hand.

Much has been heard lately, and much more will likely be heard, about the Referendum-i.e., the method by which, in Switzerland, certain measures must be, and others may be, submitted to the direct vote of the electors after they have passed the representative Legislature. Many arguments are often used for the Referendum which do not seem to me of sufficient weight. It is argued, for instance, that the Referendum is a piece of "pure and direct democracy," and is therefore good. ${ }^{1}$ This is playing with words. It does not at all follow that the direct vote of the electorate is likely to be more enlightened or better than the votes of their chosen representatives. It is argued, again, by others that

1 McCrackan's Rise of the Swiss Republic, p. 353: "The very epithets, pure and direct, satisfy our best aspirations and our common sense." Mr. McCrackan's common sense must be easily satisfied, if it is satisfied by two ambiguous words. 
the Referendum is a "Conservative measure," because the majority of the measures submitted to direct popular vote in Switzerland have been rejected. That of itself is not an argument which would commend the Referendum to every one; and it is somewhat fallacious because, we must remember, where the Referendum exists, the representatives who are opposed to a measure, or doubtful about it, are less likely to struggle against it when they know that the final decision rests with the people. Measures may have been allowed to pass the Legislature which few really expected to become law. The Referendum would certainly diminish the responsibility of Parliament, and that is a serious consideration against it.

What really seems to me the great merit of the Referendum is that it would simplify the moral problem for the conscientious voter. In voting in a Referendum an elector is asked to say "Yes" or "No" to one particular measure. Now, a general election in this country is often said to be one mode of taking a Referendum-of referring a question to the electorate. But is a general election nowadays ever fought simply on one question and one question only? The elector is asked to give a very complex decision, to decide practically which of two groups of persons shall be entrusted with the administration 
of the country at home and with Imperial affairs abroad for perhaps six or seven years. He knows that his vote will be counted in deciding the fate not of one measure, but of several, some of which he may approve and to some of which he may be strongly opposed. Why, for instance, should a vote given for Local Veto or Welsh Disestablishment be counted as a vote for Irish Home Rule? Why should a vote against these measures be counted as a vote against Irish Home Rule? The Referendum would make it possible to keep different issues separate from one another. That is its great recommendation. Nevertheless, we must recognize that it would probably be fatal to our present system of Cabinet government. In Switzerland it has introduced what in some ways may seem an even better system. The Ministers need not be all of one party. They are chosen by the Assembly for their administrative capacity, and, though they are chosen afresh every three years, the same persons are often re-elected again and again. ${ }^{1}$ The Swiss

1 "Since 1848 only two members who were willing to serve have failed of re-election. The permanence of tenure becomes astonishing when we consider that from 1848 to June 1893 there had only been thirty-one Federal Councillors in all, of whom seven were still in office. The average period of service has, therefore, been over ten years."-Lowell, Government and Parties, Vol. II., pp. 203, 204. 
Federal Council is more like the board of directors of a well-managed company, or the trusted committee of some steady-going private society, than like the party Cabinets to which we are accustomed. Whether such advantages could be realized in other countries may well be doubted. Under favourable conditions they might be hoped for. The strongest reason for adopting the Referendum should certainly be the knowledge that the elector could then give his vote at an election really for the candidate whom he considered the best man, and not simply for the set of miscellaneous measures he least objects to; and he would afterwards have the opportunity of voting separately on each important measure by itself.

Some one may very likely object that all this talk about the importance of the elector's vote is exaggerated. In a large country the individual elector, it may be said, counts for so small a fraction, and it does not matter how he votes or whether he votes at all. Just let us suppose every one to argue in that way; that is the refutation of the argument for indifference drawn from the smallness of the direct influence exercised by any one voter. Besides, it must be remembered that voting at parliamentary elections is only a part of the political power and political duty of the citizen. There are 
all the various local bodies in whose existence the citizen and his family are very directly interested; and in voting in a town council, parish council, school board, or poor-law board election the individual voter counts for more than in a parliamentary election. He has, therefore, on every ground, less excuse for indifference. His vote counts for more; he is more directly and immediately interested; he has more means of knowing the merits of the different candidates and their different policies; and it is, or ought to be, possible to keep the election free from Imperial party politics. It is, indeed, difficult to resist the tendency to apply the same party machinery to local and to Imperial affairs; but it is a tendency which the elector should resist as much as he can. What does it matter what opinion a parish councillor has upon Irish Home Rule or upon Egypt, or South Africa? Local bodies are administrative and not legislative. They have to carry out the laws made by Parliament efficiently and honestly. And the choice of suitable members for them is, therefore, a different thing, and a much less complicated thing, than the choice of a member of Parliament. Parties may, indeed, form themselves in local bodies. It is even well that they should, as it proves interest in local affairs. But there is no reason why the parties should be 
the same as those in Parliament. It is very unfortunate that so languid an interest is taken by the average citizen in local politics, that only a small fraction, even of those who vote in a parliamentary election, vote as a rule in school board and town council elections. The intrusion of the party divisions of Imperial politics into municipal and other local affairs is sometimes defended on the ground that it makes them more interesting; but it is a fictitious and irrelevant interest. I think the newspapers do some harm by reporting municipal elections as "victories" for Conservatives or Liberals. If our town councillors elected our M.P.'s, there would be good reason for this; but, as it is, the use of town council elections to show "how the tide is running" is responsible for much confusion of issues. It is a good thing that in the London County Council, where very definite parties have formed themselves, they have adopted other names than "Conservative" and "Liberal."

But the duty of voting at more or less distant intervals does not exhaust the duty of the citizen with regard to politics, Imperial or local. The elected representatives-nay, even rulers who are not elected-are dependent on the continued support of public opinion, and public opinion is something that is always being formed or modified, and to 
which every one is constantly contributing new elements of good or evil. Not merely those who make political speeches, and those who write political articles, but every one who talks on the news of the day, who passes judgment on public men and public events, is engaged in the work of making public opinion. We have not learnt fully the Constitution of a country when we know how its Executive and Legislature are composed and how the suffrage is distributed. We have only been told about the machinery, we know nothing yet of the force that works it, unless we know what kind and degree of political consciousness there is among the people, how far it is active and alert. There is among the writings of Ferdinand Lassalle, the brilliant agitator who first formed the Social Democratic party in Germany, a thoughtful and eloquent speech in which he deals with the question, "What is a Constitution?" He shows how the spirit of military discipline in the Army, the power of great capitalists and of bankers, the prevalent opinions on questions of right and wrong, all affect the actual working of a Constitution; and how the mass of the population have little or great influence in proportion to the activity of their interest in political questions. Public opinion is the force that moves the machinery of the Constitution, and 
it thus may be said to be a part of the actual working Constitution, as distinct from its legal form. Votes, as a matter of necessity, are counted; but, in the last resort, they are not merely counted, but weighed. A person with strong convictions, still more a group of persons who have strong convictions and stick well together, will get others to vote with them, and possess much more actual power than their numerical strength would warrant; whereas the listless and indifferent, even if they vote, count for much less in determining the result. It is in this sense we may say that votes are weighed. But, observe, what is weighed is force of conviction and zeal in propagandist work, not necessarily political wisdom.

The distinction between force of conviction and political wisdom is an important one. Professor Huxley somewhere tells a story of an Irish cardriver, who was asked where he was going, and answered, "Sure, and I don't know, but I'm going at a great pace." Going at a great pace is not quite a perfect substitute for knowing where it is best to go to and how it is easiest and safest to reach our destination. Bcsides the duty of taking an interest in politics, the citizen has a duty to know as much as he can about political matters, about the constitution of his country, about the actual state of 
the law on different points, about the powers of local bodies-nay, also, about the history of his country and the history and constitution of other countries. For we can only understand institutions properly when we know how they have come to take their present shape, and how they differ from institutions that may fairly be compared with them. Now, such information is not always easy to obtain, especially for those whose leisure is scanty and who have not ready access to books. But a great deal of it can be obtained in the public libraries of our large towns, and a growing demand for political information will help to create the supply. Those who have once taken to such studies will admit their fascination. A book like J. R. Green's Short History of the English People, or like Mr. Bryce's great work on The American Commonwealth is, perhaps, not exactly like a really good novel, but it is better reading than the mass of ordinary novels, and it is a far better investment of time and eyesight, for it leaves more of value behind. Even Blue Books, or such volumes as The Statesman's Year Book, or The Colonial Office List, with a little squeezing can be made to yield a very nourishing and not unpalatable food for the mind that has once awakened to an interest in the genuine study of politics. As we know, it is not always those 
who have most leisure and easiest access to books who read most of what is profitable for the education of the citizen. Our schools might do more than has yet been attempted to teach the elements of politics-I do not mean to turn out premature little Radicals or Primrose Leaguers in short frocks, but to teach the meaning of that machinery of local and general government to which the grown-up citizen supplies the real working force, not merely by his occasional vote or by his occasional presence at a political meeting, but by his habitual attitude of mind in ordinary talk or discussion on public questions. Journalists, naturally, think a great deal of themselves and their profession, and they are quite right to do so. But after all it is only the exceptional journalist that manages to lead and guide public opinion to any considerable extent. The average journalist simply supplies the kind of stuff his readers want, and, if he imagines he leads public opinion, he is like a weathercock thinking that it makes the wind blow. In the last resort it depends greatly on the average reader what the journalist supplies, whether he gives fair and accurate and full political information, or whether he only gives violent partisan statements and caricatures of opposing views, whether he takes an intelligent or 
an unintelligent attitude, a high or a low tone on questions of national duty.

Talking politics has long been a habit of Englishmen and Scotchmen, and it is a very excellent habit. Of course, a great deal of the talk, especially when it is between those who take opposite sides, may seem to produce more heat than light. Still, it is always worth knowing what your opponents are saying; and sometimes even those who have a vehement controversy with one another may come to influence each other's ideas. It is certainly advisable to hear or read what the other side says sometimes, and not to cover one's eyes with a party newspaper. But a discussion gains in value the more it is based upon serious study of the subject. The serious student of politics will be less dogmatic and more tolerant of those who differ from him, than the man who simply gets hold of a few party watchwords and does not really reflect upon the bearing of institutions and of events at home and abroad on the well-being of those he cares for and of his country as a whole. There is, indeed, a kind of toleration that is based simply upon indifference to the subject discussed; but there is a higher kind that is based upon wide knowledge and on a sense of the difficulty of the subject which excludes the assumption of infallibility. It is a 
civic duty to know what one can about public affairs, to be always ready to learn, and to seek to convince those who differ from us by sound arguments and not by forcible language.

Political and social phenomena may be and should be studied scientifically. There is a science of politics, a science not easier, but in some respects more difficult, than mathematics and physics, because the facts it deals with are much more complicated. Since practical arts, like navigation and engineering, are dependent upon the sciences of mathematics and physics, should not the practice of politics be likewise dependent upon the science of politics? But, if so, does it not seem absurd to call upon the average citizen, occupied with the cares of his daily toil for the support of himself and his family, to pronounce an opinion upon these difficult and intricate problems of politics, to tamper with the social organism whose structure and functions he has never had a proper opportunity of studying? This is often made an argument against all democratic government. It is not, however, a valid argument in favour of any kind of aristocratic government that has ever existed outside of Plato's ideal commonwealth. The business of government cannot wait till the science of politics is perfected. The art and the science must rather progress together. 
The sound inference from the difficulty of the science of politics and the consequent difficulty of the practical art is that details should be left to experts-the wisest and honestest experts we can find. It is the duty of the person who puts himself forward as a candidate for Parliament-still more of the man who considers himself worthy to be a Minister of the Crown-to study as carefully as he can the subjects he deals with. The duty of the ordinary citizen cannot in this respect be so arduous. $\mathrm{He}$ is called upon to choose among the professing experts who solicit his vote. $\mathrm{He}$ is called upon to choose between different sets of general principles. Even in the Swiss Referendum the citizen is not asked to vote upon the details of the measure, but only upon the measure as a whole. Not to leave details to experts and specialists is simply bad business management. But the more knowledge and thought the citizen can bring to bear upon his choice between candidates and between principles and upon his daily judgments on public matters, the better for the well-being of his country and the better for the spirit in which the business of its government will be carried on. 


\section{V. \\ I 792.-YEAR I. ${ }^{1}$}

FAMILIES and nations and churches-in fact, all communities of men-have recognized the ethical value of the commemoration of past events. The anniversaries of births, marriages, and deaths are remembered in the family circle. Schools, universities, societies, celebrate their centenaries. A feeling of piety, in the old Latin sense of that term, links the young to the old, the present to the past. As each of us may recognize certain dates as turningpoints or crises in his individual life, so it is with the associations or communities to which we belong. And some nations can celebrate their birthdays, or the day when they came out of bondage, or the festival of their resurrection from the dead. In this matter of national celebrations Great Britain, partly because of the fortunate continuity of our recent

1 A lecture to an Ethical Society in 1892 , published in the International Journal of Ethics, October, 1892. 
history, is less fortunately placed than some other countries. All citizens of the United States of America can join in celebrating the Declaration of Independence. The present French Republic has shown a wise instinct in choosing the Fall of the Bastille as the anniversary to be commemorated: that date for the new epoch divides the sympathies of Frenchmen less than any later date in the stormy history of the great revolution. Englishmen have given up celebrating the Whig triumph of I688; they have given up celebrating the Battle of Waterloo. The feeling grows (as we trust it may grow in Germany) that a battle is, in any case, not the best kind of event to celebrate; a national animosity is not the national feeling we wish to keep alive. And, besides, there are many victories in the past which we have come to regard with very mingled feelings. The Battle of Waterloo ushered in a very gloomy period of European history, - a peace, under the patronage of the "Holy Alliance," that was sadder than some wars. Certain national events used to find a place in the Anglican Book of Common Prayer-the Gunpowder Plot, the so-called "martyrdom" of King Charles, the Restoration of his son, and then, with characteristic inconsistency, the landing of William of Orange, tacked on to the Gunpowder Plot. But 
these commemorations were wisely abolished in 1859 . They accentuated the political partisanship or the purely selfish patriotism of the Anglican Church. Some of them were offensive even to many sincere Churchmen.

Commemorations of a grander and wider character are the recurring festivals of the Christian year. Even those who have been trained in Puritan traditions, and have been taught to feel a religious abhorrence of the "keeping of days," may come to envy other Christians the system which lights up the seasons of the natural year with the memory of events, or supposed events, in the life of the founder of their religion, and with the names of its saints and martyrs. And the Puritan himself, turning away from the precise periodic commemoration of the story of the gospels, gave all the more of his thought and sentiment to the national legend of the Hebrew people, which had already supplied a permanent historical background to the poets and prophets of the "Old Testament." The fall, the deluge, the call of Abraham, the coming out of Egypt, the conquest of the Canaanites, the tragic story of Saul, the glories of the reigns of David and Solomon, followed by the sad record of disruption and decay, the Babylonian exile, the return from captivity, and the building of the second 
temple, form a series of mythical and historical pictures which has furnished a medium for religious ideas and a language for religious emotion, and which might well serve as a typical representation of much that is most significant in human history, and a means of impressing certain moral and political lessons that never lose their value and necessity. That righteousness alone exalteth a nation, that the tyrant and oppressor is hated of God and man, that the king is bound by a covenant to his people and has no divine right to rule badly, that Providence is not always on the side of the big battalions, however much this may seem for a time to be the case, but on the side of those who have most faith in their cause, most perseverance, most discipline, most fidelity to one another and to the principles for which they are struggling,-these are some of the maxims which many generations have been taught, along with some more doubtful lessons, by the primitive philosophy of history contained in the Jewish Bible. What are called "prophetic" and "apocalyptic" books constitute, it should be observed, in a special manner the earliest philosophies of history. They are the attempt to vindicate the ways of God to man,-i.e., to exhibit the history of the world as the fulfilment of a righteous purpose and a rightcous judgment. 
Mr. John Morley has remarked on the advantages which civil and political liberty have derived from the fact that the Puritans corrected the two passive doctrines of the New Testament by a zealous study of the history of the most rebellious people that ever existed. Putting the matter with less sarcasm, if with less point, we may say that it has been fortunate for Christendom that its sacred book contained the fervently and fiercely patriotic literature of the Old Testament, full-we can hardly say of political wisdom (which we must not expect from Orientals)-but full of vehement denunciations of tyranny and oppression, full of democratic sentiment, veiled under a theocratic form. With the New Testament writers, as with the later Stoics and the Neoplatonists, the shadow of the Roman Empire is over all, for good and for evil. The Empire secured peace and abolished distinctions of race and caste; but, in the absence of representative institutions, it gave no scope for political energy. Political apathy had thrown man back on the solitude of his own soul. Although the disciples of Jesus were taught to pray, "Thy will be done on earth as it is in heaven," they looked too readily for the near coming of the heavenly kingdom as the destruction of all earthly society, and not as its regeneration. Religion and morals had become non-national, and 
even anti-social, as a preparation for becoming international and universal.

We have a larger Bible open before us than the Old and New Testaments combined,-nay, larger even than the Bible with the Apocrypha added and the library of the Fathers besides. We do not look for teaching to Judea alone, nor to a certain limited list of canonical Scriptures. "Authentic writings of the Most High," says Carlyle in a fine outburst, "are they found in old books only? They are in the stars, and on the rocks, and in the brain and heart of every mortal." 1 Or, as it is expressed in these lines of Mr. James Russell Lowell's :

"Slowly the Bible of the race is writ, And not on paper leaves nor leaves of stone;

Each age, each kindred, adds a verse to it, Texts of despair or hope, of joy or moan.

While swings the sea, while mists the mountains shroud, While thunder's surges burst on cliffs of cloud, Still at the prophets' feet the nations sit." ${ }^{2}$

If the teaching of Nature be often too obscure, at least we have the "Bible of History,"-not the story of one chosen people only, but the record of all that is great, noble, and significant, in the history of mankind. And if it be objected that history

1 Reminiscences (" Edward Irving "), ed. Norton, ii. 206.

2 Bibliolatres. 
is too uncertain, too confused, too conflicting, to teach us anything, one must point out that history only shares these difficulties with the Bible which is limited to the Old and New Testaments. It is difficult in both cases to know what is genuine and authentic; it is difficult to interpret the text when we are assured that it is genuine; it is difficult to decide between, or to reconcile, contradictory statements ; and opposite lessons can be drawn even from the same passage. The histories of Greece, of Rome, of modern Europe, and the prophets and poets and moral teachers of various ages and nations do not suggest more conflicting ideas and emotions than are obvious to any one who will read the Bible with scientific care and without the previous assumption of a dogmatic system to guide him.

In this "Bible of History" there is no chapter more significant for us, and scarcely any more difficult to interpret, than the French Revolution. It is not enough to class it along with other political and social phenomena known as "revolutions." In many respects, indeed, the French Revolution only repeats the incidents and, with some changes, the ideas of the English Puritan Revolution of the seventeenth century. The abolition of the legislative privileges of the clergy and nobility, the abolition of royalty, the trial and beheading of the king, 
the attempts at constitution-making, the military dictatorship, nay, even the assertion of the rights of man, ${ }^{1}$ may all claim English precedents. But the French Revolution had a spirit of active cosmopolitan proselytism which was absent from its English counterpart. The English revolutionary ideas spread slowly, and in course of time, transplanted to different soils, they produced the American and French Revolutions. But the French Revolution was directly and consciously a world-significant event in a sense in which the English and American Revolutions were not. It is a movement that we can only compare with such events as the rise of Christianity or the Protestant Reformation. It is one of the great turning-points in the affairs of men. Historical study shows, indeed, more and more that the French Revolution is not an inexplicable volcanic eruption of hidden and mysterious forces; it makes in reality no sudden break in the course of events : it was being steadily prepared long before. And indeed, as Mazzini has said, it "was rather a résumé than a programme." But this preparation in the past is no peculiarity of the French Revolution. It is true of the Protestant Revolution

${ }^{1}$ See The Clarke Papers, edited by Mr. C. H. Firth for the Camden Society, pp. lx.-1xv., 325. 
before it. It is true also of the rise and spread of Christianity; even the most orthodox and least scientific of ecclesiastical historians admit, in words at least, that the new religion was not entirely new, and that it came only "in the fulness of time."

But while we recognize this continuity in human affairs, as in the realm of mere nature, it is still true that we can fix on particular events in which long-prepared movements culminate. There is a definite moment at which crystallization takes place, at which thoughts and feelings are suddenly translated into deeds. And such great decisive moments may be fitly chosen for special remembrance and as centre-points of careful reflection. In a truly "catholic" calendar the fall of the Bastille and the proclamation of the French Republic should assuredly find a place. September 2I, I792, is a date one naturally thinks about when the hundred years have run out; and it is right and reasonable to ask ourselves, How does it look to us now? Though the new Republic was born after the frenzied horror of the September massacre, we know with what rapture the event was hailed by many of the wisest and best men at that time living. The German philosopher Kant, then approaching threescore years and ten, when he heard of the founding of the Republic, shed tears of joy, and exclaimed, "I can 
now say, like Simeon, 'Lord, let Thy servant depart in peace, for mine eyes have seen Thy salvation.'” Our own Wordsworth speaks of the emotion produced by the earlier period of the Revolution in the mind of a young man :

"Bliss was it in that dawn to be alive, But to be young was very heaven."

We know, alas! what bitter disappointment and disillusion awaited the enthusiasts, - the reign of terror, the Revolution devouring its own children, the awakened patriotism and heroism of the French nation spending itself in wars of conquest, the Republic destroyed by its victorious general, the dreary years of reaction and repression. And even now, when at length a Republic seems securely established in the nation that has gone through all these storms and sufferings, how prosaic it seems, how far short of a political ideal! It is "the government that divides France least": it is a compromise between conflicting interests and passions. It does not rouse enthusiasm elsewhere. The oppressed of all nations do not hail it with rapture. Kings do not tremble on their thrones because of it; the very Czar of Russia can be its ally. The republican faith has ceased to be a religion, as it was in the days when a republic seemed hopeless; it has become at best 
a calm opinion about the most convenient way of managing the business of the community. Our problems and our aspirations seem to have become different from those of the National Convention of I792. We do not think that kings and priests are always the sole, or even the worst, enemies of mankind. We do not think that the declaration of the rights of the individual and the framing of a republican constitution will suffice to bring about the reign of peace and justice upon earth. We have become aware of a silent revolution,- the "industrial revolution" we call it,-which was going on at the same time as the political, and which brings problems to us that the French Revolution did nothing to solve, and something even to aggravate. We are inclined to give way at times to a sort of political pessimism, and to ask in a despairing tone whether, after all, human beings are, on the whole, happier and better when national aspirations have been gratified and when political and civil liberty have been obtained.

Think of some of the events that have occurred within the lifetime of most of us. We have seen with our own eyes what poets, patriots, martyrs have longed to see and have died without seeing. Things pronounced impossible by the strong and mighty have come to pass, wrought out by faith and 
perseverance and sacrifice,- $a$ united German nation, an Italy risen from the dead, Christian nationalities freed from Ottoman oppression, slavery and serfdom abolished throughout the civilized world, many reforms put into practice and accepted as a matter of course which it used to be treasonable even to advocate, a republic apparently securely established in France, and the various enemies of the republic withering and perishing before her as if they were smitten by some vengeance of fate; and with all this we feel how little has been done to make life better for individual men and women.

But is not this feeling of disappointment a salutary necessity of human progress? Let me use some of those time-honoured Biblical illustrations of which I spoke. When Israel wandered forty years in the wilderness, how those who died in the wilderness envied those who were to enter the promised land! But those who entered the promised land found that they were only at the beginning of their struggles. The captives who sat down and wept by the waters of Babylon, remembering Zion-when their feet trod again the streets of Jerusalem, were their sorrows at an end? The temple of the Lord had still to be rebuilded. The angels, in the evangelist's story, sang the glad tidings of "peace on earth" at the birth of Christ; but, though His disciples regarded $\mathrm{Him}$ as 
the expected Messiah, did they not hear Him say, "I came not to send peace, but a sword"? Every step onward and upward in our individual lives, in the lives of human socicties, brings us in vicw of fresh heights to be reached, new difficulties to be overcome. Every attempt to read the meaning of history makes us aware of the slowness with which real progress is effected. This is the old problem with which, in a theological form, the religious Hebrew tried to grapple: Why does God delay to judge the world? The souls of the martyrs, in the Apocalypse, cry out, "How long, O Master, the holy and true, dost Thou not judge and avenge our blood on them that dwell on the earth?" And many suffering souls seem always crying, if not for vengeance, yet for justice.

The pessimistic feeling we are apt to have especially about the French Revolution is, among ourselves, partly due, I think, to the fascination of that great prose epic poem in which Carlyle has pictured its history. One great lesson, and one only, does Carlyle draw from the "fuliginous, fiery mystery" which he describes,- the inevitable doom of all rotten institutions. But reading this purcly ncgative lesson, the everlasting damnation of whatsoever liveth and maketh a lie, he sees nothing but an apocalyptic vision of the pouring out of the vials of the wrath 
of God. Individual portraits and particular outward scenes stand out with startling vividness before us. But who could gather from the pitying scorn of Carlyle's references to the National Assembly and the National Convention that these bodies were doing a vast amount of solid legislative work,-work which has lasted and endured, much of which even the Restoration did not dare to meddle with? The apparent failure of the Revolution must not blind us to the ultimate triumph of its ideas. The French Revolution and its culmination in the first French Republic had not merely the negative result of revealing to the whole world the utter rottenness of the old régime: they have affected for good the government of every country in the civilized world, not excepting our own, always too tolerant of ancient abuses; not excepting even Russia, in which the abolition of serfdom may be traced ultimately to the ideas of '89-though these ideas have still work enough before them there. The abolition of slavery (so often incorrectly claimed by the Church), the freedom of opinion, the idea that government exists for the pcople and by the will of the people,-these are principles by no means peculiar to the French Revolution, but which gained their clearcst and most conspicuous expression in it. The ideas of ' 89 may be found, 
as I have already said, in the American Revolution, and before that in the English Puritan Revolution of the seventeenth century. They may be traced among Protestant, and especially Calvinistic, writers of an earlier date, and even in the middle ages, when the priest was the only tribune of the plebs, and when the rivalry between the spiritual and the temporal powers led Papal champions to teach the sovereignty of the people and Imperial champions to assert the freedom of intellect. Nay, the ideas of the French Revolution may be traced further back still, not only to the republican ${ }^{1}$ enthusiasm of Greece and Rome, but to the democratic ${ }^{1}$ sentiments of some of the Hebrew prophets. A modern French writer ${ }^{2}$ has said that the French Revolution in its aspirations was "the unconscious testamentary executor of the prophet Isaiah." There is among Hebrew prophets and among French revolutionary enthusiasts the same confident expectation of a reign of peace and righteousness, the same fierce denunciation of vengeance on the oppressors of the poor and on the selfish luxury of the rich; nay, even the same rejection of traditional ceremonial

1 I contrast these terms; for the ancient republics were all, in the modern sense, slave-holding oligarchies.

2 M. Anatole Lercy-Beaulieu, quoted by Laveleye, Le Gouvernement dans la démocratie, i. $27 \mathrm{I}$. 
religion in favour of an ethical Deism, and the same excusably patriotic belief that their own nation was the chosen people, through whom the redemption of the whole world was to come.

Governments may still disown the ideas of ' 89 and ' 93 , but those ideas have been, and are, working. The doctrine of the sovereignty of the people-i.e., that rulers are the servants of the nation and not its irresponsible masters-practically influences every European Constitution, except those of Turkey and Russia, which survive as specimens of the kind of government that some persons affect to admire, in a thoughtless impatience with the defects of parliamentary institutions. If reformers nowadays do not feel the same hostility to monarchy which their predecessors felt in the earlier part of the nineteenth century, is it not just because the French Revolution and its republican ideal-i.e., its ideal that every true Constitution must be a "commonwealth"-have done so much to ameliorate the character of monarchy? Kings can no longer get rid of moral responsibility to their subjects by claiming; as of old, to be responsible to God alone. We are too apt to forget how much effort this change has cost, and how much the civilized world has gained by it. It is said that after Culloden a ragged Highlander, a fugitive from 
Charles Edward's unhappy army, broke into a cottage where a poor old woman was weaving cloth, and seized enough to make himself a coat. The old woman, attempting in vain to hinder him, exclaimed, "Ye'll pay for't!" "When?" said he. "At the day of judgment." "That will be lang credit; she'll tak' a waistcoat, too." The rulers of mankind have been in the habit of getting this "lang credit." The struggle for political liberty, which culminated in the French Revolution, has meant the refusal of it. Kings now may or may not claim to rule by the grace of God: they do rule by the grace of their people. Similarly, if reformers feel less of hostility to the old Churches, even to the Roman Church, than they used to feel, is it not because the Churches have had their intolcrance checked, their abuses diminished, their zeal in good works quickened, by the direct and indirect effects of the French Revolution itself? The Protestant revolt had in some ways a beneficial effect on the Roman Church-where Protestantism was sufficiently strong to keep it in check. And the French Revolution has, in the long run, had an effect even more striking and more beneficial on all bodies of Christians; for the French Revolution proclaimed those ideas of "Liberty, Equality, Fraternity," which the Christian Churches had professed in a spiritual 
sense, while too blind or too feeble to translate them into outward acts. Thus theological apologists are in the habit of claiming that the abolition of slavery is due to Christianity. But you will find that there is a startling difference betwcen the usual attitude of theologians and Churchmen generally to this subject before the French Revolution and after it. The abolition of slavery is due to Christianity, certainly,-but only in that sense of Christianity in which the French Convention must be accepted as not less an exponent of Christian ideas than the Ecumenical Council of the Vatican or the Anglican bench of bishops. But the orthodox representatives of Christianity are naturally reluctant to reckon Rousseau and his followers among the "Doctors of the Church."

If the lapse of a hundred years makes us recognize that the gospel of the French Revolution is no longer a sufficient gospel for us, if we feel that the declarations of the rights of man contain a very partial recognition of the truth about human society, and that the faith in abstract principles is apt to become a rather narrow and meagre creed, we must not despise the necessary work of freeing the individual from a blind submission to the yoke of king and priest,- a work that is not altogether nor everywhere completed yet. To destroy an effete, and 
therefore mischievous, type of social existence, and to prevent that type of society being ever permanently restored again, was a necessary task, for which the world owes undying gratitude to the prophets and heroes and martyrs of liberty, as liberty was understood and had to be understood a hundred years ago. To construct better social forms, to recognize the social needs and the social duties of the individual, is the task which falls to us; but it is a task made possible, as well as necessary, by the destructive and liberating work which went before. Those who have to lay the foundations of the new building need not disparage the dangerous work of those who had to pull down a collection of ruinous and unwholesome structures.

We are inclined perhaps to smile a little sadly at the calm confidence with which the National Convention set to work to make all things new, cutting themselves adrift from the past, symbolizing their faith by altering times and seasons, and placing themselves at the outset of a new era-the year I. It is impossible thus to break with the past. Just as the sins of his fathers were visited on the wellintentioned but incapable man who found himself king of France when the day of judgment and vengeance dawned, so the enthusiasts of the new era were caught unawares in the meshes of the past, 
inheriting its ideas, its wisdom, and its folly. It is never the year I.: there is no absolute beginning in the history of humanity, any more than there is in the course of nature. In every department of life, in politics, morals, and religion, in literature, art, and science, there are apt to be two opposing camps,those who think that everything is revealed already, that they possess permanent and authoritative truth ; and, on the other side, those who catch at the newest phrases and the newest fashions, and think that all mankind have hitherto sat in darkness, and that a "new era" has suddenly begun in their own generation, that a quite "new spirit" is operating in the world. Neither of these opinions can be correct. All really living old ideas must in their very growth renew and re-create themselves. It is when this growth is checked and hindered that revolutions and convulsions occur. And, on the other hand, the new must be born of the old. Those who most violently break away from the past often carry about with them dead and encumbering fragments of it. A sympathetic knowledge of the past is the best preservative against its delusions. A true reverence for the past is essential to sound and healthy social life: it is one of the fundamental "pieties" of existence. But the truest reverence for the past is a reverence which will always prefer the living 
spirit to the dead letter. A "Protestantism" that has sunk into the acceptance of traditional dogmas, the cult of a Revolution which erects its declarations of rights into barriers against social reform, are examples of that mere formal outward consistency which means unfaithfulness to the living spirit.

And so, if we are to turn to any practical account our reflection on the events of a hundred years ago, we must ask ourselves: How can we imitate the reforming spirit of that time and yet avoid similar errors? What are the crying evils of our own time? How can they be remedied? And how can they be remedied so that, if possible, new evils may not arise from the very remedies themselves? We may make many errors,--we are certain to do so,- - but honest failures are at least more educative than sitting still and doing nothing. And if a consciousness of the admixture of evil with good in all human effort is apt to paralyze our energy, we must remind ourselves that admixture of evil is at least as certain to be present in a timid policy of keeping things as they are. And we must resist the temptation to pessimism by keeping before us the true scientific conception of evil,as "want of adjustment," "want of cohesion," "incongruity,"-a conception which allows us to regard evil as self-destructive. 
I have said that there never is a "year I," and yet it is also true that every year may be to us a year I,-to us in our individual lives, as well as to the society to which we belong. A new resolution deliberately formed and patiently acted out, a new work undertaken and zealously performed, a new and better adjustment of our relations to those around us, may date a real epoch in our lives, to which we and others may look back in after years with satisfaction and gratitude.

There are times when the inexorable tyranny of the past, both in regard to our individual life and in regard to national and social existence, seems to oppress us and weigh us down with a feeling of fatalistic despair. But if a careful study of history gives us this sense of the unbroken chain of cause and effect, it also shows us how the ideas of solitary and despised thinkers may gradually, and in spite of many apparent failures, work themselves out into practical realization, so that the dreams of one age become the commonplaces of another. And so it is in our individual lives. "Free-will," in the sense of an arbitrary and absolute power of initiation in every individual at every moment, is an unscientific delusion; but human beings are, by the power of thinking, raised above mere nature. Or, to express it otherwise, ideas 
are themselves natural forces, in that wider sense of "nature" which includes conscious as well as unconscious existence. A vivid consciousness of what we ought to do, and habitual reflection on it, become causes influencing conduct. "Conversion" is not the mere dream of religious fanatics; it is a psychological fact in the experience of many individuals. Well is it for us, if the moral revolutions which quicken our energy, our sense of intellectual honesty, and our recognition of social duty, can take place without pain and convulsion and the tearing asunder of old and dear ties.

It is a great gain that the history of the French Revolution can now be studied and thought of without blind abhorrence and without blind partizanship. "Let us never glorify revolution," it has bcen said by Mr. Goldwin Smith; "statesmanship is the art of avoiding it." And it is not only the statesman that has to seek to avert revolution, but every citizen, by helping to reform abuses and by keeping on the alert to prevent them accumulating, by public spirit, by intelligent sympathy with suffering, by honesty and conscientiousness in the exercise of all public functions, among which must be included the function of forming and criticizing opinions,- a public function in which we all share. It is a terrible thing when 
the redemption of a people has to take the form of vengeance, the wild justice of unchained slaves; but does not the heavier blame rest with those who kept a people in slavery than with those who broke their fetters?

When we are sagely criticizing the acts of the men of 1792, awarding our praise and our blame, more able at a safe distance to see a few redeeming points in the old régime, and with the benefit of knowing all that has happened since, it is right to ask ourselves how our own generation will be judged at the bar of history a hundred years hence. Will people then look back on this period as a time of doubt and feebleness, of uncertain beliefs and selfish timidity, or will they be grateful to us for facing our intellectual and our social problems boldly and honestly? Will they be able to pardon our mistakes and our delusions, because of the spirit in which we tried to leave the world-not worse, but a little better than we found it?

Now and then a mocking voice may be heard to ask: Why should we do anything for posterity? What has posterity done for us? We, the men and women living now, have our own urgent needs to satisfy : let us fit the world to our needs. After us-the deluge. It is impossible to reason with those who really think in this way, and do not merely 
speak with that foolish affectation of cynicism which, of all affectations, is one of the least excusable. We can only say, "Verily, they have their reward" -in their selfish isolation. They are withdrawing themselves in their egotism from the ranks of humanity-nay, even from a place among the higher animals. By mere instinct the bird will toil, and will even die, for its young ones; and shall we, who inherit from the labours of those who have suffered and died such privileges (to name no others) as our opportunitics of knowledge and our right of free speech, shall we disown the claims of those who are to come after us? Surely this, if anything, might be called "blasphemy against the Holy Spirit!" It is faithlessness to humanity.

Less than a month after the Republican calendar was introduced (October, I793) there was enacted in Paris a scene than which there is hardly anything in history more dramatic and more touching. Twenty-one Girondist deputies stood on the scaffold awaiting their death, and as they stood they sang the Marseillaise hymn in a chorus of which one voice was silenced every minute by the guillotine. They were suffering, not like other martyrs at the hands of their enemies, - that could have been more easily borne; they were doomed to death in the name of the Republic which they had themselves 
helped to create. And yet, in this bitterest of all disappointments, they sang their song of triumph. The critical historian is apt to be impatient with those eloquent Girondist deputies, who talked when they should have been acting; and there is no need to delude ourselves into thinking that the man who can die nobly or dramatically is therefore wise or just. But there was something more than courage in the way these Girondists faced death and disappointment. It was an act of faith, for which we owe them our gratitude and our reverence. They "did not despair of the republic"; they did not despair of humanity. And the world necds faith in humanity as well as insight into its weakness. 


\section{VI. \\ WAR AND PEACE. ${ }^{1}$}

THE framer of an idcal polity may find it 1 convenient to place his perfect commonwealth in some inaccessible region of the world. It simplifies the internal problems of political society to isolate the state; but such simplification means abstraction from the actual truth of facts. The practical reformer who is keenly interested in some constitutional change, or in legislation which he thinks will ameliorate the social condition of the mass of his fellow-citizens, is apt to be impatient with politicians whose minds seem to run away to the ends of the earth. But the enthusiast is inevitably the man of one or of a few ideas. The impartial student of politics and the really wise statesman must have eyes for international as well

1 Published in the International Journal of Ethics, January, Igor. A few sentences have been added and the "Note" at the end. 
as for domestic affairs. Even the constitution of a state cannot be fairly judged without considerațion of the questions, whether there are dependent communities in other parts of the world whose welfare must be directly affected by the character of the home government, whether the territory of the state is compact or scattered, whether its frontiers are well defined by "natural"-i.e., geographicalboundaries or determined by artificial treaty-made lines cutting through regions where no barriers of water or rock hinder easy communication, whether the natives beyond the frontier are strong or weak, civilized or barbarous, militant or peaceable. Political institutions and habits of government, which may work well in a community secure against outside interference and even against direct outside influence, may prove unworkable and disastrous in a state dependent for its food supplies or for the employment of its workmen upon safe communication with distant countries, or exposed to the attack of an ambitious and excitable neighbour or to the incursions of semi-barbarous and ill-governed hordes.

The Utopian state which has no neighbour must still have some means of compelling obedience and of repressing disorder within its own bounds, unless its inhabitants are supposed to possess automatic 
virtue and to live at peace through a pre-established harmony. The actual state, which is one among many states, which has neighbours and commerce, must be prepared to resist attack from without and to protect its scattered children and dependents. Most persons would, indeed, regard this as the primary and least disputable of all the functions of the state; and, as a matter of history, it is mainly through the necessities of military defence that peoples have become conscious of their unity and have submitted to the authority of government. War has ever been the great maker of nations. There are some, however, who would get rid of the difficulties of foreign policy in an easy fashion by declaring that all war is wrong, while others allow war only when it is "just" (in their opinion), or they allow it in case of self-defence, but condemn it when it is what they call "aggressive." The Quaker moralist, Jonathan Dymond, lays down in his Essays on the Principles of Morality (published originally in 1829; 9th edition, 1894, p. 270), that all war, even in self-defence, is wrong, because contrary to "the peaceable precepts of Christianity," such as, "Resist not evil," "Love your enemies," "Unto him that smiteth thee on the one cheek," etc. In a commendatory Introduction written for some previous edition of the work, 
John Bright uses these words: "If we may presume to ask ourselves, what in the eye of the Supreme Ruler is the greatest crime which His creatures commit, I think we may almost with certainty conclude that it is the crime of war." The inaccurate term "crime" is clearly here used as a rhetorical equivalent for "sin." The religious anarchist, Count Tolstoy, living more fully in Eastern ideas than was possible to the Exeter linen-draper and the Rochdale cotton-spinner, takes the words, "Resist not evil," as forbidding not merely war, but all use of force on behalf of morality or social order. The Quaker casuists are not so consistent. "It is the duty of the civil magistrate," says Dymond, "to repress the violence of one man towards another, and by consequence it is the duty of the individual, when the civil power cannot operate, to endeavour to repress it himself. . . Many kinds of resistance to aggression come strictly within the fulfilment of the law of benevolence. He, who by securing or temporarily disabling a man prevents him from committing an act of great turpitude, is certainly his benefactor. ... It is an act of much kindness to a bad man to secure him for the penalties of the law" (p. 135). This is quite in the spirit of Plato's Gorgias. Jonathan Dymond has strong opinions about bad debts, and approves of all 
insolvency being treated as a crime (p. 195)-possibly a wise suggestion from the commercial point of view, but not very much according to either the letter or the spirit of the Christian gospels. There is some want of logic in this honest tradesman's adaptation of the precepts of Oriental idealism; or rather, perhaps, it is a want of imagination. $\mathrm{He}$ sees the necessity of protecting his household, his shop and his carnings against the ruffian and the rogue; but just because the Army and the Navy had been so successful in their business in the last great European war, he does not, amid security and peace, realize that they have done anything at all for him and his. If a wretched tramp steals a pocket-handkerchief-off with him to prison. If a Napoleon threatens the commerce and the constitutional liberties of Great Britain, fold your hands and ingeminate "peace, peace." Any arguments that are valid for the maintenance of law-courts, of policemen and of prisons, are valid also for the maintenance of a system of defence against attacks from without and for the protection of the routes of commerce. Even if we get rid of patriotic sentiment, we cannot be certain that every invader, if we did not resist him, would maintain as good a system of internal peace and justice as we have at present, nor that he would be equally tolerant of 
conscientious refusals to wear weapons and serve in the wars at the commandment of the magistrate.

Do the Christian Scriptures, on any fair interpretation, actually condemn war? Not one of the texts habitually quoted as condemning it relates to contests between nations. "All they that take the sword shall perish with the sword." These words were uttered in condemnation of resistance to civil authority, even when unjustly used (Matt. xxvi. 52). There are many passages which condemn rebellion even against despotic government based upon conquest: "Render unto Cæsar the things that are Crsar's"-i.e., pay the taxes imposed by the Imperial Government; "Let every soul be in subjection to the higher powers: the powers that be are ordained of God"; "Honour the king"-i.e., the Roman Emperor. Such precepts support the Roman Empire and were expressly intended by those who uttered them to discourage Jewish aspirations after national independence. It was the Roman conquests and the strong military despotism of Rome which gave the world the peace and order and toleration that made the spread of the Christian religion possible. The ascetic John the Baptist tells the Roman soldiers to abstain from violence and wrongful exactions-i.e., from looting, or in any way ill-treating the civil population. His precepts 
are precisely those of any respectable general of a modern army sufficiently disciplined. $\mathrm{He}$ tells them to be content with their pay; he does not treat the soldier's profession as in itself wicked. $\mathrm{He}$ does not call them hireling murderers, or say that they are earning the wages of sin. Jesus and Peter do not tell the devout Roman officers who come to them that they must leave their unhallowed calling. Moral precepts such as "Love your enemies" are addressed to individuals, not to nations, which are only metaphorically persons: and such precepts are, perhaps, more often fulfilled by the brave soldier who has no hatred in his heart against the individuals of a hostile nation, than by those preachers, politicians, and journalists. who seem to think the commandment means, "Take the side of the enemies of your country, and prove your righteousness by imputing corrupt motives to her statesmen." Whether turning the other cheek to the smiter, giving to all borrowers and beggars, and making things easy for the thief (Matt. v. 39-42) are compatible with civilized and orderly society, is a question which need not be discussed at present. In any case, these "counsels of perfection" are clearly addressed to individuals, and they are not the precepts which the members of peaceable industrial communities are specially ready to obey. 
"A nation must be prepared to fight: but it ought not to fight except in a just cause." This opinion expresses the sentiment of the average peaceable citizen who is not a Quaker, nor an anarchist, religious or otherwise. But what does it mean? "War is right-when it is right." Justice requires to be determined: and since the time of Plato's Republic that has been found a difficult and lengthy matter, except by those who are content to fall back upon their own instincts or prejudices, or to follow some guide which they suppose to be infallible.

No Christian community, except the Quakers and some similar sects, condemns all war. Thomas Aquinas discusses some of the texts to which I have referred, and gives his own conclusion as follows (I quote from Father Rickaby's translation):

"There are three requisites for a war to be just. The first thing is the authority of the prince by whose command the war is to be waged. It does not belong to a private person to start a war, for he can prosecute his claim in the court of his superior. .... The second requisite is a just cause, so that they who are assailed should deserve to be assailed for some fault that they have committed. Hence Augustine says: 'Just wars are usually defined as those which avenge injuries, in cases where a nation or a city has to be chastised for having either neglected to punish the wicked doings of its 
people, or neglected to restore what has been wrongfully taken away.' The third thing requisite is a right intention of promoting good or avoiding evil. For Augustine says : 'Eagerness to hurt, bloodthirsty desire of revenge, an untamed and unforgiving temper, ferocity in renewing the struggle, lust of empire [Libido dominandi,-i.e., of arbitrary rule. Our word 'Empire' does not necessarily mean that],- - these and the like excesses are justly blamed in war." -Summa, II. 2 ; qu. 40.

It may be noticed that Augustine includes the avenging of injuries among just causes of war. Some modern sentimentalists, careless of the accuracies of language, speak as if "avenging wrongs" meant the same thing as indulging the evil passion of revenge. Augustine and Thomas Aquinas fall into no such confusion. Thomas Aquinas does not raise the problem of the possible abolition of all war. To get rid of private wars, to keep the clergy from fighting, and to mitigate the ferocity of combatants seemed sufficiently urgent reforms to the philosopher of the thirteenth century.

Let us turn from the "angelic doctor" of the mediæval Church to the Thirty-nine Articles of the Church of England. A curious alteration is to be noted in the wording of the clause about war in Article XXXVII. In the original Latin form it is: "Christianis licet, ex mandato magistratus, arma portare, et justa bella administrare," or, as it 
was put in the English version of 1552 : "It is lawful for Christian men .... to serve in lawful wars." In the Article as it has remained since 1562 , the word "lawful" is omitted before "wars." "It is lawful for Christian men, at the commandment of the magistrate, to wear weapons and serve in the wars." Had the English bishops and Queen Elizabeth's Government come to recognize the inconvenience of leaving it to the individual conscience, no longer guided by a Church that claimed infallibility, to decide which wars were just and which were not ? ${ }^{1}$ It may be argued, indeed, that in such a brief declaration it is honester and wiser to leave out a term like "just" or "lawful," of which no definition is given. The Westminster Confession of Faith, Ch. xxiii., clause 2, declares that "it is lawful for Christians to accept and execute the office of magistrate, when called thereunto: in the managing whereof, as they ought especially to maintain piety, justice, and peace, according to the wholesome laws of each commonwealth; so for that end, they may lawfully, now under the New Testament, wage war upon just and necessary occasions." "This seems to leave a good deal open to the individual's judgment.

1 The discrepancy is pointed out by S. H. Reynolds in his edition of Selden's Table Talk (Oxford: 1892), p. 5, note. 
What laws are "wholesome"? What occasions are just and necessary? Those who have accepted the Westminster Confession have not usually felt their stern religion inconsistent with the use of the "argument of pike and gun" at the command of their lawful magistrates and, on occasion, even against "the powers that be."

Archdeacon Paley, whom we may take as a good representative of the average reasonable citizen, applying Christian precepts on utilitarian principles, writes as follows in his Moral and Political Philosophy, Book VI., Ch. xii. :

"The justifying causes of war are, deliberate invasions of right, and the necessity of maintaining such a balance of power amongst neighbouring nations, as that no single state, or confederacy of states, be strong enough to overwhelm the rest. The objects of just war, are precaution, defence, or reparation. In a larger sense, every just war is a defensive war, inasmuch as every just war supposes an injury perpetrated, attempted, or feared.

"The insufficient causes or unjustifiable motives of war, are the family-alliances, the personal friendships or the personal quarrels of princes; the internal disputes which are carried on in other nations; the justice of other wars; the extension of territory or of trade; the misfortunes or accidental weakness of a neighbouring or rival nation."

This passage has much historical interest. The repudiation of mere dynastic reasons for war, the 
stress laid on the balance of power, the nonrecognition of wars of liberation or of the sentiment of nationality, are all characteristic of the eighteenth century. What Paley says in the second paragraph is considerably modified by what he goes on to say. After insisting that what statesmen ought to consider is not extent of territory, but raising the greatest quantity of happiness out of a given territory, he adds:

"There are, indeed, two cases in which the extension of territory may be of real advantage, and to both parties. The first is where an empire thereby reaches to the natural boundaries which divide it from the rest of the world. Thus we account the British Channel the natural boundary which separates the nations of England and France; and if France possessed any countries on this, or England any cities or provinces on that side of the sea, the recovery of such towns and districts to what may be called their natural sovereign, though it may not be a just reason for commencing war, would be a proper use to make of victory. The other case is where neighbouring states, being severally too small and weak to defend themselves against the dangers that surround them, can only be safe by a strict and constant junction of their strength; here conquest will effect the purposes of confederation and alliance; and the union which it produces is often more close and permanent than that which results from voluntary association." [This is illustrated by the unification of England and of France, respectively.]

Besides the rule of prudence which consists in 
preferring internal happiness to extent of territory, save in the cases mentioned, Paley recognizes also the maxim, "never to pursue national honour as distinct from national interest." But he adds : "This rule acknowledges that it is often necessary to assert the honour of a nation for the sake of its interest." Thus Paley's utilitarianism keeps him from applying his principles in too abstract a fashion. He does not limit just wars to wars of self-defence, and he gives to self-defence a very wide interpretation. He sees, as every reasonable and prudent citizen must see, that cases may arise where the safety of a nation may require its government to appear formally as the aggressors. There is certainly a widely spread and very proper feeling that self-defence is the least questionable justification of the use of force; but self-defence is not an unambiguous term, and people have been known to invade and annex their neighbour's territory and declare that they were only doing it in selfdefence. We must not judge the right or wrong of a war by laying too much stress on the mere form of aggression. It may be important to know who struck the first blow; but it is also important to know what each of the combatants was doing and saying before, and not merely immediately before, the outbreak of hostilities. To limit just 
wars to those where an attack has been already made by the enemy might be to condemn the more conscientious nation to destruction.

The word "defence" is not as free from ambiguity as it may seem in abstract political ethics: neither is the word "self," when applied to a nation. Is it reasonable to regard the existing geographical boundaries of nations at any given moment of time as absolutely fixed de jure divino and to call every attempt to alter them unrighteous aggression? How can those who propose to stereotype the political map of the world in 1900 accept with approval many of the changes that have taken place since $\mathrm{I} 800$ and since $\mathrm{I} 700$ ? If an existing nation has a moral right to defend itself, has the struggle to attain national existence never had any justification? On the other hand, has every nation that in any sense exists at any time an absolute moral right to maintain its independence against the general interests of larger groups of human beings? A nation, after all, is only by metaphor an individual organism or person. A human being, as a moral person, as a subject of rights and duties, must be a member of some society, but not necessarily of any one particular society. Nations exist for the sake of mankind and not mankind for the sake of nations. A nation may come 
into being or may be absorbed in some wider community; and the birth of a nation or the absorption of a nation may be either good or evil for the human beings affected.

Let me consider some of the judgments we are in the habit of passing on historical events at a sufficient distance from our own times to enable us to see them in proper perspective. We disapprove, let us say, the partition of Poland, but regard it as inevitable because of the anarchical constitution of the country. We approve of the American colonies fighting for their independence against the stupidity of George III. and his Ministers, although we see that war might have been avoided had the British Government been in wiser and more enlightened hands. We disapprove of the rebellion of the Confederate States, although admitting that the South Carolina Declaration of Independence of I 860 has a greater show of quasi-legal right than the Declaration of 1776 : we approve of the determination of the Federal Government to carry on the war to the end without listening to proposals of compromise or arbitration, and with such strenuous severity as was necessary to bring it to a conclusion. We may perhaps condemn the British Government for engaging in war against the French Republic in 1793, but we approve of the war against Napoleon, when it 
became clear that he was aiming at a general domination over Europe. (An interesting change of sentiment towards the war with France may be noticed in the utterances of Robert Burns. In 1794 he proposed the ambiguous toast: "May our success in the present war be equal to the justice of our cause," and nearly had to fight a duel with an officer. Later on, he joined a volunteer company and wrote patriotic verse.) We may admit that Switzerland and Italy gained indirectly by being conquered for a time by the French. The restored Swiss Constitution had to treat the inhabitants of Vaud and Ticino no longer as subjects, but as equals. Italy, after long slumber, received the ideas of unity and constitutional government. The Venetian Republic, mourned by Wordsworth, was a decayed oligarchy; and the idea of a new "Italy" was of more value than the picturesque shade of a city state. Out of the Napoleonic wars came, partly by Napoleon's own revolutionary policy, partly by reaction against it, the nationality movement which has transformed the map of Europe in the nineteenth century. The unification of Germany, the liberation of Italy from foreign rulers and its unity under constitutional government, the emancipation of Greece and the Danubian states from Turkish oppression and misrule, the recognition of the 
Hungarian Constitution-these changes, all of which might have seemed impossible in the beginning of the century, are now accomplished facts, and are by all believers in political progress regarded as advances in human well-being, however poor may seem the prosaic reality when measured by the hopes of the poets who sung and the enthusiasts who died for these causes. Every one of these changes has been directly or indirectly brought about by war. The Crimean war is not now generally regarded in Great Britain with the enthusiasm to which Tennyson gave such magnificent utterance. To buttress up the decaying Ottoman Empire seems a poor reason for so much suffering; and the only country which may seem to have gained anything from it was, perhaps, Italy. The intervention of Sardinia in a quarrel with which it had nothing to do may seem contrary to all the precepts of Paley or any other moralist; and yet the bold action of Cavour may seem justified by the result,he obtained a place for Sardinia in the counsels of Europe and a hearing for the cause of Italy. Could Italian independence have been won without the intervention of Napoleon III., dictated, partly perhaps by sentiment, partly by self-interest? Yet such intervention would have to be condemned, if self-defence alone justifies war. And what are 
we to say of the raid of Garibaldi into Sicily without the authority of his lawful sovereign? Many Roman Catholics make it almost an article of faith to abhor the seizure of Rome by Italian troops in I870; and yet an obscurantist ecclesiastical government upheld by foreign troops may well seem to have few claims on our sympathy. There was a good deal of sympathy with Denmark in 1864 , on the ground that Denmark was a small state attacked by two large ones; most of us would feel now that that was a somewhat irrational transference of schoolboy ethics to international disputes, and that the German states had a very good case. Many of us take the side of Prussia against Austria in I866, because Prussia was the more progressive country, and because Italy and Hungary, and Austria itself in the long run, gained by the issue. Mr. Herbert Spencer, who has a special horror of everything that he calls "militarism," nevertheless speaks of the acquisition of Alsace and Lorraine by Germany as a punishment of the French for their aggressiveness (see his Principles of Ethics, I., p. 318). Most of us probably feel that the question cannot be so simply settled; that those who pushed Napoleon III. into a war for which the French Army was not prepared were doing France a grievous wrong; that Germany was, perhaps, justified in reclaiming 
provinces that had been German once, but that these provinces, though German in population, had become so French in their sympathies that some treatment short of annexation-e.g., neutralization-might well have been adopted if compatible with the security of the German Empire, but that now every year that passes makes them more and more German.

Some of these wars may be judged differently by many readers; and in every case a much more detailed statement would be requisite before any judgment could be quitc fair. But let anyone take the judgments he would pass on these or any similarly varied cases, and I think he will find that we do not restrict our approval to wars of selfdefence, that we do not approve self-defence under all circumstances, that there are some cases in which we approve of absorption of smaller states by larger, that there are cases in which we excuse intervention of third parties in quarrels with which at first they had nothing to do, and that we sometimes approve war even when begun without the authority of any already existing sovereign. Can any principles be found underlying such judgments? In the first place we ought not to disguise from ourselves the fact that our judgments after the result are based largely on success. If we do not exactly say that all successful wars are just wars, we admit that 
no nation is justified in engaging in war unless with a reasonable prospect of success. We may forgive or admire the courage of desperate men fighting for a lost cause; but we should condemn a government which knowingly led a people into what (apart from miraculous intervention) must prove a hopeless contest or which continued it after it became clear that a prolongation of bloodshed and suffering could not affect the ultimate issue, except perhaps by inducing the victor to impose harder terms. The sympathy so often expressed for the weaker or smaller state, simply because weaker or smaller, is æsthetic rather than ethical: it is really a survival of that barbaric feeling about warfare which regards it as a noble sport. If a small state inflicts on a large state injuries which would justify war, if inflicted by a state of equal power, there is no sufficient reason for abstaining from demanding redress, with war as the alternative, simply because the war is likely to be successful. It is recognized that a revolution is never justified except by success, though we may excuse individuals who have engaged unsuccessfully in rebellion for what we regard as a good object with a reasonable prospect of succeeding. There seems no reason why the same maxim should not apply to wars. 
In judging past events, we are more influenced by results which affect large numbers of persons than by the small personal occasions of them which may have attracted most attention at the time of their occurrence. In judging of present events we are often so much occupied with apportioning responsibility to individuals that we are apt to neglect the larger currents of human affairs which individuals have only a limited power of diverting or controlling. Aristotle has said of revolutions that the occasions of them may be trifling, but that men do not rebel about trifling things. And now that wars are great national affairs in which rulers cannot engage without very widespread national support, we may apply Aristotle's profound remark to wars also. The anecdotal historian, the gossiping journalist, and the political partizan attacking the government, like to trace the origin of a war to the intemperate or uncivil language of some diplomatist or statesman or to the interested schemes of some self-seeking financier. The personal devil is convenient for those who like facile explanations and wish to have some one to lay the blame upon. But such explanations are not very scientific. The responsibility of individuals is more difficult for human beings to estimate fairly than the tendencies of events and institutions when seen on a sufficiently 
large scale, and I think it will be found that our judgments on the wars of the century from 1770 to 1870 turn very largely on the question, Which of the conflicting forces was making for constitutional government and for social progress? or, to put it in wider terms, Which represented the higher civilization? And thus it is that we may sometimes approve the rise of a new state and sometimes the absorption of an old. Words like "inevitable" or "manifest destiny" are apt to be used rashly or dogmatically. But there is everywhere an inevitable conflict between inconsistent types of civilization; and with human nature such as it is, and human governments such as they are, this conflict cannot always be kept in peaceful channels. Wars should never be judged as isolated phenomena. They are incidents or symptoms of larger movements. The divine right of kings and constitutional government, society based upon slavery and society based upon labour for wages, ecclesiastical domination and lay liberty, the principles of the Holy Alliance and the principles of the French Revolution, the statecraft of Metternich and the ideals of Mazzinioppositions like these are irreconcilable, because they are the oppositions of different stages of human development; and compromises between them have only avoided war for the time being, sometimes 
at the cost of a more terrible struggle afterwards. War is a harsh form of dialectic, a rough means of solving hard problems; but war, or the genuine threat of war, is often the only way-for there are always people, especially the champions of reactionary and antiquated types of rule, who will recognize no argument unless it is backed up by sufficient force. If you are pleading with the Turk, for instance, on behalf of persecuted Christians, a demonstration of ironclads proves your argument more effectively than maxims of religious liberty and peaceable progress in which the fanatical Mohammedan disbelieves and about which the corrupt official does not care. The pity is that Armenia has no sea coast, so that what has been done in diverse ways for civilization in Grece and in Crete and in Egypt, cannot be done in Armenia, except by Russia, the most backward of the great Powers of Christendom.

Some wise person (I do not know who) has said: "I am for peace at any price-even at the price of war." The evils of war may have to be endured for the sake of a more lasting and more widespread peace than could be obtained without them. In judging wars by their success, and in apportioning responsibility beforehand by considering the likelihood of success, we must take account not merely of victories in the field, but of the 
establishment of orderly government afterwards. "Providence," it has been said, "is always on the side of the big battalions." That is not true, unless the big battalions are also well disciplined, skilfully led, and the commissariat properly cared for. That is to say, military success, in the long run, does prove the possession of certain moral and intellectual excellences. And the nation which not merely conquers, but maintains its conquests and governs subject peoples so as to give peace and security to races previously harassed by constant wars, or which assimilates them to any considerable extent, so as to spread civilization over a larger portion of the world-such a nation has justified itself in the judgment of history, which, as Schiller said, is the world's Day of Judgment. The wars of nationality which have characterized the nineteenth century are wars of a higher type than the dynastic rivalries in which peoples were too often merely the counters with which princes played. Wars fought by citizen-armies, whether under conscription or as voluntary soldiers, are wars of a higher type than those fought by foreign mercenaries. The nationality movement marks a great step in human progress. But we are allowing our ideas to crystallize if we suppose the nation-especially the nation which represents only one homogeneous race-to 
be necessarily the highest and final type of political society. The political philosophers of Greece could not see farther than the autonomous and independent city republics; and we know that small city states with their intense eager life, though they contributed so much to the intellectual greatness of ancient Greece and of mediæval Italy, condemned Greece and Italy to constant internal war, to foreign conquest, and to loss of political freedom. Representative institutions have made the self-governing nation possible; but we have no right to assume, with some political theorists, that a great number of comparatively small independent nations, leaving the barbarous and savage races of the world to "work out their own development," represents either the highest type of human society or a possible, type. May not a few great "empires," in which selfgoverning federated communities control the less advanced races, represent a higher stage, more likely to be stable, less exposed to war, and preparing the way for a federation of the world?

The word "empire" has been applied in very different senses; and it is easy to praise or to blame "imperialism" by laying stress on one meaning or on another. The early "empires," as we call them, of Assyria, Babylon, Persia, etc., were the result of mere conquest of territory in order to increase the 
fame and the wealth of the governing race. The conquered peoples were, unless very rebellious, left to themselves, provided they paid tribute. The Ottoman Empire is a survival of this type. It has been well described as "anarchy plus the taxgatherer." The conquests of Alexander of Macedonia belong to a higher stage, because he seriously set himself to plant Hellenic civilization in the East and to unite the more civilized "barbarians" with the Greeks. But he left no permanent political or legal institutions. The Roman Empire is the first real example of an empire which gave laws and institutions and citizenship to its subjects. The Roman Empire was a military despotism, because the idea of representative government did not yet exist, and only a city state could then be a selfgoverning commonwealth. But the Roman Empire gave Europe, Western Asia, and Northern Africa such peace as they had never enjoyed before and such as they have never had since. The pax Romana proves, perhaps, that the blessings of mere peace are over-estimated by those who realize the horrors of war, but have had no experience of the evils of stagnation and torpor. The British Empire in India is in some respects the closest parallel that exists to the Roman Empire in the Mediterranean lands. The problems of India arise largely from the internal 
peace which allows the growth of a population vastly greater than ever existed there before. India has been acquired in a curiously haphazard fashion, and the story of its conquest has some dark pages. But the governing of India is a responsibility which Great Britain cannot shirk except at the cost of throwing its many races back into such anarchy as would speedily invite some other conqueror. The rule of India brings with it other heavy responsibilities in other parts of the world, responsibilities which must soon be shared by a federation of all the self-governing communities that make up what is called the British Empire-if that empire is to last. The late Mr. Freeman, with a keen sense for the historical antiquities of political terms, used to urge that "Imperial Federation" is an absurdity. So it is, if we are looking solely at the empires of the past. But just as representative government was the great political invention of the Middle Ages, so federation (as distinct from mere leagues or confederacies) is the greatest political invention of modern times. To the Greek philosopher a republican nation would have seemed an impossibility. A federal empire (like Germany), a federal republic, a federation of self-governing communities with dependencies more or less autocratically governed according to their degree of 
civilization-all these forms now seem possible to us.

In politics it is always difficult, but most necessary, to avoid being the slaves of words-especially of words that have been used as party cries. Do not let us assume that a government is necessarily of a higher type because it calls itself a "republic," or that it represents despotism and oppression because it is called a "monarchy" or an "empire." So-called "republics" may be narrow oligarchies in which those of a particular race or a particular religion rule the other inhabitants despotically. What are called monarchies may be in a true sense commonwealths, and what are called empires may be more under the influence of democratic ideas than some republics. Irrespective of names, we have always to try to find out which is the cause of order and progress, which of misgovernment and reaction. The words "national freedom" and "independence" attract our sympathies; but the "freedom and independence" of a caste of nobles, of an intolerant clergy, or of an exclusive and unprogressive race may mean the denial of freedom and opportunity for development to the more progressive part of the population. When the Swiss Federal Government put down by force of arms the Sonderbund and expelled the Jesuits in 1847 , it is 
easy to represent that as an interference with the independence of the Catholic cantons-the original home of Swiss liberty; and the war really meant the final overthrow of the ancient type of lax confederation and the restriction of "state rights." But to those who believe at all in human progress, this forcible suppression of the separate league, like the American civil war, meant a real step forward.

The abstract principle of non-intervention is no more a tenable maxim in international politics than is the principle of laissez-faire in domestic politics. Some nations by their geographical position or by the compact nature of their territory are happily more free than others from the difficulties and responsibilities that may arise for all civilized and progressive peoples. If our neighbour had a tiger roaming in his garden and making our garden dangerous, we should probably shoot the tiger if he refused to lock it up or could not manage to do so. Anarchy and disorder in a neighbouring state cannot always be overlooked. And from a distant state there may come a cry for help from kindred in race, religion, or stage of civilization, which may seem to justify intervention, provided intervention is possible with a fair prospect of escaping other international complications. Stay-at-home persons may find it easy to accept the principle that 
every people should be left to work out its own problem for itself-as if every people were a unity or a person in the same sense. But the enterprise of the trader and the zeal of the missionary carry them into barbarous and savage lands; and nonintervention on the part of their countrymen may become a very difficult policy to maintain, and a policy which may only lead to unchecked cruelties on the part of the less scrupulous white adventurer and to the martyrdom of the nobler representatives of civilization. And both these things are likely to bring about intervention, spheres of influence or acquisition of territory. It is false to speak as if acquisition of territory in tropical lands, which the white man cannot permanently inhabit, were entirely due to lust of gain. That might be more truly said -where people do not usually say it-of the settlement of white races in temperate countrics already inhabited by lower races. The desire to suppress the slave trade and the obligation of defending fellow-citizens have been important factors in the overthrow of the independence of various African despots. The acquisition of territory inhabited by lower races has in no case, perhaps, been free from some harshness and ill-treatment of the natives; and where the natives do not die out or diminish with the advance of European civilization, the 
conquering nation has to face very difficult problems. But it is as "inevitable" that vigorous and enterprising white races should overflow into other lands as it is that water should run down hill. And the state which simply shuts its eyes to what its citizens are doing-for good or evil-in distant lands is shirking its responsibilities under the plausible pretext of non-intervention. What used to be the favourite method, the plan of giving charters to trading companies, was a compromise between doing nothing and undertaking a task-one of the many compromises in the world which creates fresh difficulties instead of settling any. It is unreasonable to suppose that the political atlases of this year will be quite correct a hundred years hence; and to discuss the ethics of the relations between nations and between higher and lower races on that assumption is to substitute an abstract science for a consideration of urgent practical problems. The moralist, who does not profess to base his judgment on an absolute and detailed code revealed to him by supernatural authority or by the light of Nature, must be content to regard the struggle for existence between nations and between types of civilization as of itself helping to determine political right and wrong. But he must guard against crude applications of biological conceptions to social evolution. The nation is not 
an organism in the biological sense; the same human being may belong to many social organisms, and the extinction of the less successful social organism does not necessarily mean the destruction of the individuals belonging to it. In other words, human evolution does not take place only by death and by war.

What prospects are there of war giving place to less cruel methods of settling international difficulties? Not so long ago the hopes of many were stirred by the Czar's Rescript proposing a reduction of armaments. The proposal came strangely from a country which at the moment was increasing its military expenditure ; and to some it has occurred that Russia is the country which could most easily reduce its armaments, for it need not fear attack or invasion. It is easy to put down "progressive reduction of armaments" in a programme of international reform. But how are states, rightly alert for the interests of their own subjects, to be induced to accept such a scheme? Who is to fix a maximum force for this or that particular country? Who is to determine whether so many less infantry and cavalry in one nation are really the equivalent of so many fewer ironclads in another? Furthermore, would it be altogether in the interests of peace or civilization that a state which has been brought to 
the verge of bankruptcy by excessive expenditure should be put in a position of equal military advantage with a country whose credit is sound because it has good government, and an educated, enterprising, and industrious population? Wars will not be diminished by being made less costly. The huge citizen-armies of modern times are a heavy financial burden. But when we contrast them with the hireling adventurers with whom princes and republics carried on their wars in previous centuries, we see that great progress has been made not merely in the manner of conducting war, but in the serious sense of responsibility with which it must now be undertaken.

The Hague Conference rightly gave most attention to more practical matters - to amendments in the laws of civilized warfare and to schemes facilitating resort to arbitration. The quiet work of international jurists from Gentilis and Grotius down to the present time has done far more to help on the interests of humanity and to diminish the physical and moral evils of war, than all the rhetoric of peace societies. The horrors of warfare have been mitigated not by a sentimental shrinking from all severity, which could only prolong struggles and give the advantage always to the less scrupulous and less humane party, but (I) by the establishment 
and enforcement of a rigid distinction between combatants and non-combatants, involving stern punishment for any participation in the struggle by those who have claimed the privileges of noncombatants; (2) by such increased strictness in military discipline as makes it possible to check the lawlessness that characterized the soldiery-especially the foreign mercenaries-of earlier times; (3) by the prohibition of the destruction of private property "unless imperatively demanded by the necessities of war"-an important exception; and (4) by systematic provision for the care of the sick and wounded and of those who have bona fide laid down their arms.

Arbitration is a valuable remedy, but it is not a panacea; and the cause of arbitration is only injured by the notion that it can be made a substitute for war in any and every case. Arbitration, in the sense in which the term is used in international law, is only applicable between nations whose international status is recognized and mutually admitted. It is inapplicable where the main ground of dispute is the claim of one party to be a sovereign independent state and the refusal of the other party to admit that claim. If the United States Government had attempted to avoid bloodshed by submitting to foreign arbitration the questions 
between the Federal Government and the Confederate States, that would have been tantamount to granting all that the Southern seceders demanded. In cases where arbitration is perfectly applicable, the limits within which a question is submitted to arbitration must be very carefully laid down. The British Government was perfectly right in submitting to arbitration the frontier dispute between Venezuela and British Guiana; but it was, I think, perfectly right in refusing to submit the matter to arbitration unless bona fide occupation by British subjects for a considerable period, under the belief that they were settling in British territory, were taken as evidence of British dominion. To leave a question of frontiers to be settled entirely by charters and maps of centuries ago would be to fall back into the feudal manner of treating human beings as if they were mere appendages to the soil. If ownership of territory were to be determined irrespective of actual occupation and of seizure by force, what claim could any people of European descent have to any inch of American ground? Arbitration as a substitute for war may be compared to litigation as a substitute for trial by combat; but the analogy is not exact. A war is not an artificially regulated encounter like a duel; it is one form of natural selection. Arbitration about frontiers is not litigation 
about ownership; civilized sovereignty does not mean the same thing as ownership of property. It is mere careless rhetoric when acquisition of new territory is spoken of as "robbery" or "burglary" : individual property rights may not be disturbed in the least, and may even be better secured than they were before. It is abstract thinking if questions of sovereignty are suffered to be settled by ancient documents without regard to the interests and convenience of actual human beings.

It is more than a hundred years since Kant wrote his essay on "Perpetual Peace." Kant saw quite clearly that there is only one way in which war between independent nations can be prevented; and that is by the nations ceasing to be independent. If we wish to know how war is to cease, we should ask ourselves how it has ceased. Why is there no longer war between England and Scotland? Why did Prussian and Hanoverian fight side by side in I870, though they had fought against each other only four years before? The armed peace of the German Empire may not be an ideal condition of society; but it is infinitely better than the acute agony of the Thirty Years' War or the chronic maladies of the Holy Roman Empire-an empire which rested only on sentiment and had no armed force to support it and to keep its subject princes 
from fighting with each other. The rise of modern nations meant the suppression of private and tribal wars and of wars between rival cities. The absorption of smaller nations into larger political bodies means the prevention of war within great areas. In the ancient world, as we have seen, a despotic government seemed the only means by which this peace could be obtained. Representative and federal government open up other ways. Kant's project for a universal federation includes the stipulation that every state must have a "republican" government, but by that he only means a representative government. It is quite clear that a court of international arbitration cannot cnsure the enforcement of its decisions, unless it is the tribunal of a federation, with federal troops to check rebellion. It need not be thought that the soldier will ever become useless on this earth, although his duties may be more and more assimilated to those of the policeman.

Switzerland is one of the smallest of nations, but perhaps it offers more suggestions than any other of the means by which great changes may be effected. Switzerland is already the headquarters of many international bureaus and conventions. Switzerland has a Constitution which maintains national unity without destroying cantonal institutions. It unites different races, different religions, and four languages. 
Its Army system, which enforces military drill on every young man before he obtains the privileges of citizenship, is so managed as to interfere very little with industrial pursuits and to be an excellent training-school of civic education. For one set of problems Switzerland offers no help. A federation of civilized nations may be possible when they are all constitutionally governed; but there may also remain large parts of the earth unfit for constitutional government. Tropical lands are apt to become black anarchies or whitc tyrannies; and in the interest of black and white alike the controlling hand of governments influenced by the ideas of temperate and civilized countries is absolutely necessary. Our federation of "free states" will have territories under it, which must be governed more or less despotically by a trained and capable civil service. This is a federation of the world, which is not an altogether visionary ideal. The "European concert," international postal and tclegraph bureaus, the Geneva Convention, intcrnational congresses of all kinds, existing federal institutions-these are the germs out of which may grow the diminution, the mitigation, and, possibly, the cessation of wars. 
NOTE ON THE PRINCIPLES OF THE PEACE CONGRESSES.

LEST I should seem to have unduly disparaged the wellintentioned efforts of peace congresses, it may be worth while to give some specimens of the "abstract thinking," as Hegel would have called it, in which these bodies indulge. At the Congress held at Rome in r89r a number of resolutions were passed, which are still cited (e.g., this year, I90I, at Glasgow) as "fundamental principles."

(I) "The principles of morality and of law for nations are similar to those applicable to individuals" (in another translation "resemble those applicable to individuals"). It is not said that they are "identical." What is the degree of similarity and what of dissimilarity? "Law" certainly does not apply to sovereign and independent nations in the same sense in which it applies to individuals within a nation whose government can use regulated force to compel obedience. The principles of what is called "international law" cannot, therefore, be strictly analogous to those which may be found in the positive law of this or that nation. As to "morality," it is true that rulers and citizens are morally bound to consider the responsibility of their political, as of all other, actions-e.g., rulers must act as trustees for those dependent on them, and must not be generous or magnanimous at the cost of those for whom they are trustees; they must consider the welfare of their subjects at home and abroad and the interests of the unborn generations. Peace congresses seem to have 
given imperfect attention to these aspects of political morality.

(2) "Inasmuch as no one has the right to decide judicially in his own case, no state can declare war against another" (in another version "can of right"). It is, however, declared further on that "every nation has the right of legitimate self-defence." What self-defence is "legitimate"? If no state can declare war, it would follow that a nation when actually invaded may resort to arms, but that it must on no account, if it fears invasion or if it rightly or wrongly thinks its independence menaced, declare war or threaten to do so by sending an ultimatum.

(3) "Every dispute between nations should be settled by juridical methods." As I have pointed out, the cause of arbitration is not helped by demands that it should be applied in every conceivable case and without limitations and safeguards.

(4) "All the nations form one body, and they, like individuals, possess the right of legitimate self-defence." The connection between these two propositions is not very clear. If all nations were one body in the same sense in which the citizens of one country are, the right of self-defence would mean the "right" of rebellion or the right of private war-a right which no careful person would assert existed in the same sense as that in which the right of self-defence is recognized in international law.

(5) "No right of conquest exists." True in so far as there is no right of conquest in the sense in which copyright, for instance, exists where the law of this or that country has recognized it. But the right of conquest may 
be spoken of in the same sense in which we might speak of the right to existence : a nation has a right of conquest in a sense like that in which a body of persons may be said (metaphorically) to have a right to constitute themselves a nation, if they can make good their claim and can get it recognized by other nations. If any such legitimization of conquest under any circumstances is denied, is it meant (i) that there never was any right of conquest? Are the Saxons and Angles, then, to leave Britain, Europeans to leave America, and so on? And who is to enforce this absolute right of the original inhabitants everywhere? Or (ii) is it only meant that in the year $189 \mathrm{I}$ it was so decreed for the future? "Rome has spoken." The Congress must have become infected by the atmosphere of infallibility and of anathemas which the neighbourhood of the Vatican may be supposed to produce.

(6) "Every nation possesses the inalienable and imprescriptible right of freedom in disposing of itself." This principle fits in with the declaration of the Congress of 1889, "that no annexation of territory can be considered as legitimate unless by virtue of the free consent of the people concerned." This sounds very well; but what precisely is meant by "free consent"? Does it mean that a plébiscite must be taken at once amid all the excited feelings left by a recent struggle, and before there has been any experience of the effects of annexation? And what number of votes is to be held as proving a "free consent"? Is there any ultimate reason for settling matters by counting heads except that it may sometimes save the breaking of heads? Is not the right of the 
majority, in the last resort, based on the same grounds as the right of conquest-viz., on force? (Cf. Jenks, History of Politics, pp. r3r, I32.)

Suppose that the very reason or the pretext for annexation has been that one half (or one-third or two-thirds) of the inhabitants have been oppressed and misgoverned by the other fraction, to which section of the community is most weight to be attached? Is the "free consent" of the Turks, for instance, necessary to justify any extension of Greek territory?

(7) "The autonomy of every nation is inviolable." What is "a nation" for the purposes of this clause? If it means every state which at any given time is recognized as a sovereign and independent state by the Great Powers, would not the principle prohibit any interference with the Ottoman Empire? If "nation" is defined, as it is by one of the articles of the Congress of 1896 , as " a group of individuals, permanently occupying a fixed territory and taking part in the formation of a common government charged with the administration of justice and the maintenance of order," the principle would absolutely condemn the procedure of the Swiss Confederation in suppressing the Sonderbund, and the procedure of the United States in refusing to recognize the independence of South Carolina and the other seceding slave states.

The definition of "a nation" in any correct legal sense must include the absence of any habitual obedience to a determinate human superior. Apart from this defect, the words "permanently," "fixed," "administration of justice," "maintenance of order," would be interpreted very differently by different nations and races, according to the degree of 
their civilization. The principle of the inviolable autonomy of every nation would thus mean either (i) the crystallization of every existing political grouping of mankind; and this might be a worse evil than occasional warfare: or (ii) an indefinite authorization of rebellion on the part of any group of persons who considered themselves a nation; and this would not tend to promote either the peace or the progress of mankind.

"Who cannot help lamenting," as Bentham remarks about the American Declarations of Rights, "that so rational a cause should be rested upon reasons so much fitter to beget objections than to remove them ?" The "principles" of the Peace Congress of I89 I simply transfer to nations those "anarchical fallacies" which the individualist thinkers of the eighteenth century formulated in their declarations of "natural rights." 


\section{VII.}

\section{THE ULTIMATE VALUE OF SOCIAL EFFORT. ${ }^{1}$}

I a well-known passage of his Autobiography (Chap. V.) John Stuart Mill has told us of the mental crisis through which he passed-how his object in life, "to be a reformer of the world," lost for a time all its charm and value, and there seemed to be "nothing left to live for." As he says, "No doubt many others have passed through a similar state"; and, indeed, perhaps no one, save those of singularly fortunate natural temperament and exceptionally happy surroundings, no one certainly who has reflected much on human life, can have escaped at least a temporary feeling of the kind which Mill so pathetically describes. We know how readily this confession of despair has been used to

${ }^{1}$ A lecture delivered in South Place Chapel, Finsbury, London, E.C., on December 22, I889, and afterwards published in pamphlet form. 
I78 THE ULTIMATE VALUE OF SOCIAL EFFORT.

serve the purposes of theological apologists, who, finding themselves somewhat baffled by the demands of reason, turn eagerly to the impetuous logic of unreasoning feeling, and in the utter unsatisfactoriness of this earthly life find an argument for the consolations of the old faith. The alternatives seem to be supernaturalism or pessimism-in some more or less explicit form.

Any one who takes up a humanist position in ethics-i.e., who professes to believe that, apart from all supernatural sanctions, the individual ought to regulate his conduct by considering, so far as he can honestly judge, what will tend to the well-being of humanity as a whole, or at least of human society in some fairly large sense-any such person is bound to be able to give a reason for the faith that is in him, whether he be challenged by himself in a despondent mood, or by the professed adherent of supernaturalist ethics, or by the professed pessimist. Our own personal tendencies to doubt and despair can hardly be met by intellectual argument, but generally need strenuous moral efforts, or even physical remedies-as they depend so much on the state of health. But in any case, in order to be honest with ourselves, we must see whether it is possible to meet the objections of the orthodox Christian and of the more or less orthodox Buddhist. 


\section{I.}

One type of objection may be disposed of without much trouble. Remove supernatural sanctions, it is said, and there will be no check on the greed and lust of animal human nature; and so we must defend orthodoxies-even if in our secret hearts we do not believe them-for the sake of social order. Well, perhaps for the sake of some kinds of social order the maintenance of orthodoxies in which we do not believe may be necessary. The "Saviours of Society," of a certain sort, must support one hypocrisy in order to support another. The despot puts the policeman at the service of the priest, if the priest, in return, puts hell at the service of the despot. Those who use the argument that, if men shake off the old creeds they will soon take to cutting each other's throats, can never have grasped what is meant by the substitution of human for supernatural sanctions, and the consequent resolution of immoral acts into acts hurtful to the health of the social organism. To take, first of all, the very lowest ground, any one who pushes the gratification of selfish impulses to such an extent as to become a pest to the bulk of the community must be kept from mischief, or got rid of in some way or other. "If you feel no motive," says George Eliot, " to 
common morality but a criminal bar in heaven, you are decidedly a man for the police on earth to keep their eye upon." It is also worth while to remind ourselves that the Hebrew Ten Commandments, though supposed to have been given by a supernatural revelation, rested on no sanction of a future life. "Moses and the prophets," as Strauss puts it, "knew nothing of the immortality of the soul, and yet Moses and the prophets they were still." The sanction they did recognize was the judgment of God on earth, and that sanction, even though stripped of its theological form, remains to us still. "The Day of Judgment is the history of the world" -a saying which expresses one aspect of the scientific doctrine of "natural selection." If no other text in the Bible remained true for us, it would still be true that "Righteousness alone exalteth a nation." A society whose members are unfaithful to one another, who will give up no selfish indulgence for the sake of the common good-a society of profligates, cowards, and traitors-is an altogether impossible society. The most corrupt society that exists can only be kept from dissolution by some leaven of goodness working in it. There must be honour even among thieves-that is the ultimate test, that is the laboratory experiment, which proves the necessity of altruism; or rather, to put the matter 
THE ULTIMATE VALUE OF SOCIAL EFFORT. I 8 I

more correctly, which proves that the individual cannot realize himself except in a society of other individuals, whose claims upon himself he is willing to recognize. The personal satisfaction of the individual cannot exclude, but must include, the realization of social well-being.

There is no need of disguising the fact that the disappearance of a belief in supernatural sanctions does lead to an alteration in parts of the moral ideal. Some virtues may change their rank in the scale, when judged by the standard of social well-being. Many things that have been condemned come to be regarded as innocent, and some things that have been fiercely reprobated take their place among the highest duties. IVe should, perhaps, bring down St. Simeon from his pillar and set him to any honest work; while the anathematized heretics of the old creed might become the saints of the religion of humanity. We should not remove St. Paul nor St. Francis of Assisi from their niches in the temple, but we might put Giordano Bruno and Spinoza beside them. But a certain inevitable change in the ethical ideal-inevitable if there is to be progress and adaptation to changed conditions of life-is a very different thing from the disappearance of all ethical ideals whatsoever. What the world needs is a more and more thorough-going and 
I82 THE ULTIMATE VALUE OF SOCIAL EFFORT.

consistent application of the test that conduct is good or bad according as it tends to social wellbeing or the reverse, and that those who do antisocial acts and encourage anti-social feelings must be reformed-or, if that is not possible, repressed. Otherwise any society will go to pieces, however fervently its members may repeat the words of the Nicene and Athanasian creeds. The nation that has persistently done evil shall without doubt perish everlastingly, whatever may be its theological beliefs or ritual observances.

But it is often urged, in press and pulpit, that the humanitarian spirit is merely an outgrowth of orthodox Christianity, and can only for a short time outlive the decay of its parent stem. What a strange ignorance, or rather ignoring, of history have we here! Much of the humanitarian element in Christianity existed before the rise of the Christian Church. To the Stoic philosophers we owe the first distinct expression of the brotherhood of mankind; and philosophers, we must remember, only make explicit in thought what is already felt by many. Nay, cortain sceptical Greeks condemned slavery as "unnatural," whereas there is hardly any subject on which Christian theologians, Catholic and Protestant, have quarrelled less than on the righteousness of slavcry-until after the French 
THE ULTIMATE VALUE OF SOCIAL EFFORT. 183

Revolution. Much of the modern humanitarian movement has coincided precisely with the decay of orthodoxy. Much of the humanitarian spirit, now fortunately prevailing even in the narrowest of Christian Churches, is the result of the reaction upon the old creeds of the very revolt against them.

If we look for what distinguishes Christian ethics from the ethics of the Pagan world, we cannot find it in the kind of duties enjoined, but in the range of persons towards whom these duties are owing. Christianity did not introduce the duty of loving our neighbour as ourselves; but the parable of the Good Samaritan teaches that "our neighbour" may be the alien in race and the heretic in religiona lesson which the Christian Church has not always willingly received. Like the other "ethical" religions, Christianity has suffered from the constant recrudescence of the older religion of mystery and magic, the substitution of forms and formulas for righteousness of life. The "defenders of the faith" tell us nowadays that our duty to God is higher than our duty to our neighbour, and that our love to our neighbour has no firm root except in our love of God. Turn from these official exponents of Christianity to the words of Him whom Christians worship as God manifest in the fiesh-words the more certain to be genuinely $\mathrm{His}$, because the least 
I84 THE ULTIMATE VALUE OF SOCIAL EFFORT.

likely to be acceptable to a later age of definite ecclesiastical institutions and ceremonies:

"Many will say unto Me in that day, Lord, Lord, did we not prophesy by Thy name, and by Thy name cast out devils, and by Thy name do many mighty works? And then will I profess unto them, I never knew you: depart from $\mathrm{Me}$, ye that work iniquity."-MATT. vii. 22, 23.

And again :

"Inasmuch as ye have done it unto one of the least of these My brethren, ye have done it unto Me. . . I Inasmuch as ye did it not unto one of these least, ye did it not unto Me."-MATT. xxv. 40, 45.

And in a similar spirit it is saicl :

"He that loveth not his brother whom he hath seen, cannot love God whom he hath not seen." I JOHN iv. 20.

In such passages is not the service of man made the measure and the test of the only acceptable service of God? And if we turn to the history of the Christian Church, are we to say that the humanitarian spirit is the outcome of theological dogmas, ecclesiastical institutions, and ritual observances, and not, rather, that it is the humanitarian spirit which has given these their moral efficacy and vitalized what, without it, become dead or mischicvous forms of religion? 


\section{II.}

If, however, supernatural sanctions lose their hold on our minds, do not the consolations of religion disappear along with them and leave the way open to the chilling creed of the pessimist? Social reform is not then put aside as something subordinate and secondary to the preparation for a future life, but is put aside altogether, because human life at its best is not worth having. Now, what characterizes the pessimism alike of the sated but unsatisfied pleasure-seeker and of the Oriental ascetic is its absolute individualism as an ethical creed. The pleasure-seeker says: "Pleasure is good; but because it vanishes away in the getting, and the surplus of pain is greater, therefore life is evil." The ascetic accepts the pleasure-seeker's standard for judging life, and accepts his conclusion about life, but the practical inference he draws is that, since his individual desires cannot be satisfied, they must be starved. Neither of them advances to a position which places the end outside the pleasures and pains of the individual. Neither of them recognizes that human desire, alike in its lowest and in its highest forms, is social and not merely individual. If we are to balance pleasures against pains, it is very difficult to escape the conclusion that pains preponderate. 
"Count o'er the joys thine hours have seen, Count o'er thy days from anguish free, And know, whatever thou hast been,

'Tis something better not to be."

This pessimism is no new product of a complex civilization. When man had secured sufficient repose from the daily struggle for existence to look around him upon "all the works done under the sun," one of his earliest reflections was, "What profit hath man of all his labour? All is vanity and a striving after wind." Older than the great systems of Greek ethics is the tale that tells how the satyr Silenus was forced to reveal to his captor the terrible secret of human life-that "not to be born is best of all things, and the next best to die soon." To the Oriental ascetic or mystic there is "nothing new under the sun "-no forward movement-no meaning in politics, no meaning in history; and among those living under despotic government, where a change is only a change of masters, such despair is intelligible enough in the few who refiect. But in their Western imitators this despair is a treason to humanity: and this imitation of Eastern apathy is a disease arising from unhealthy conditions in modern society. Modern pessimism is justifiable, however, as a reaction against the easy-going optimism of a less sympathetic age. In the exaltation of sympathy for suffering is to be 
found the redeeming and the valuable feature in the pessimist ethics. But the hopelessness of the pessimist in the face of suffering comes from his utter disbelief in social progress and in all the attempts to remedy this suffering by improving the conditions under which men must live.

These remarks, it must be explained, apply to the philosophy of Schopenhauer, who only transferred Buddhist ideas into the Western world, but not to Von Hartmann, whose ethical creed is not necessarily inconsistent with the creed of any social reformer, except in his account of the ultimate meaning of it. We have, according to Von Hartmann, to cooperate with the world-process in order that finally all the restless striving of the universe may end in the peace of annihilation. We cannot now consider this manner of stating the destiny of the universe. We might, perhaps, raise the doubt whether it is logically possible to ask the question, "Is existence in general good or bad?" With the thoroughly consistent pessimist, as with the thorough-going sceptic, it is impossible to argue. Anyhow, for us as practical persons, here and now, wishing to know what to do, is it not enough to say, "Within the world we know and can affect there is a worse and a better"? or, if any one chooses to say, "All is bad," may we not answer, "There is a worse and a less bad"? 
I 88 THE ULTIMATE VALUE OF SOCIAL EFFORT.

Happiness may be unattainable-unattainable at least by deliberate effort-but the existence of pain and of unhappiness is a sufficient stimulus to urge us to do what we can to diminish them. For a vast multitude of human beings round us, the life they have to live-even the very best life they could under their conditions live-may seem to us hardly worth the living; but many of the evils we see admit of a remedy. Many of them would disappear if in any way the average moral dispositions of mankind could be raised (that every one is ready to admit); but many even of the moral cvils are due, not so much to the absence of good and kindly dispositions, as to blind helplessness and to want of co-operation. Ignorance and individualism are the two great impediments to our progress. Human life has never yet had anything like a fair chance; and we may most wiscly defer the question whether life in general is worth living till a time has been reached in which at least the grcater portion of men and women shall have opportunities of devcloping their capacities, such as are now with difficulty obtained by a very few, and too often at the cost of others; and if at each step we see some new reform in front of us, well, that only shows we are not yet in a position to answer the question about life in general.

Still, though we dismiss the pessimist's objection 
in this way, we cannot help the question coming up, What is the end of it all? Suppose human society to become as perfect as possible, this earth of ours has no privilege of immortality, and long before the planet perishes all living things will disappear from its surface. Is it worth while working for human society, if annihilation, whether we will it or no, is to be the end of all our effort? This counsel of despair we can only meet in the same way as before. Whatever may be the ultimate destiny of human socicty, we must at least do the best we can to make it better while it lasts. If nature is inexorably cruel, that does not excuse us from doing our best to lighten the burden of human life. "Let justice be done, though the heavens fall." 1 The uncertainty of our individual lives does not justify us in committing suicide, or in folding our hands and doing nothing, because we may only be able to do very little.

If, again, the complaint be made that a possible general amelioration of the lot of mankind in a distant future affords no consolation to the suffering individual now, we can only answer that such an objection ignores the actual instinctive solidarity of human beings. We are not such desperate

'If this phrase be taken to mean "though orderly human society be made impossible," it is mere anarchical nonsense. 
individualists by nature as certain moralists and religious teachers have made us by reflection. Many of the lower animals will face death for the sake of their little ones; and from very early days men have planted trees that, not they themselves, but their children might eat the fruit of them. There is this race-instinct to work upon at the lower end of the scale, and at the higher end is there not the unselfish desire to hand on to others a better inheritance than we have received? But perhaps it is hardly right to call this desire unselfish; for a man cannot realize his true self save in the work he does for the good of others. In the pessimist's virtue of sympathy we find the escape from the individualism that makes pessimism inevitable. It is worthy of note that Mill traces his recovery out of his hopelessness to the time when he read in Marmontel's Mémoires of the boy's resolution to supply the place of his dead father to his afflicted family. "A vivid conception of the scene and its feelings came over me, and I was moved to tears. From this moment my burden became lighter." Even an imaginative participation in the effort to alleviate the sorrow of others brings us back to our true kinship with humanity, and saves us from the despair that follows the terrible sense of isolation. 
Of the endeavour to make our lives better, which we may call by the familiar phrase, "The endeavour after salvation," there are two main forms-individual and social. In the first the individual strives to save his own soul; and if he is thoroughly possessed by this ideal to the exclusion of any other, he will do so by withdrawing from the temptations, but at the same time from the responsibilities, of ordinary human society. This ascetic life, either of the solitary recluse or of a select community, if regarded not as a mere temporary expedient, but as a "counsel of perfection," implies an utter hopelessness about the regeneration of society, whether accompanied or not by the belief in a better life after death. The ordinary religion with which we are familiar-the religion of the man who saves his soul on Sundays, and is a more or less energetic citizen on weekdays - is a compromise, or a transition, between two ultimately inconsistent ideals of life. The refusal to despair of human society upon this earth and the endeavour to make human life better by social and political reforms implies faith in humanity and in progress. We cannot build on negations, and we are not doing so. Which had the greater faith-Pope Pius the Ninth anathematizing the whole course of modern thought, or Mazzini in exile foreseeing the triumph of the cause 
for which he lived and suffered-the cause not of Italy only, but of oppressed humanity everywhere? Did the early Christian martyrs, who expected the speedy destruction of the world and faced death in the sure hope of Paradise, show more faith than did Condorcet? Though the Revolution was devouring its own children, and he had to hide himself, in daily expectation of death at the hands of his fellow-Republicans, he did not yield to despair, when despair might well have been excused him, but spent the days that remained to him in writing on the Progress of the Human Mind.

It may be said, however, that such faith is baseless. Is it? When it was believed that mankind had fallen from an original state of innocence and bliss, when men were still dominated by the myth of the Golden Age, there was greater excuse for a despondent tone about the future of human society. At the best there could only be a recurring cycle. Evolution was the movement from good to bad. But the historical and scientific researches which have ruthlessly dispelled the beautiful dream of a Golden Age are the very foundations on which our faith is based. We still often hear it said: "I had rather think of man as a fallen angel than as an elevated ape." Why should that be preferable, supposing it were true? If man were a fallen angel, 
there would be less reason for hopefulness in the possibilities before him than there is now, when we learn to what heights he has occasionally risen from the level of the brute. If existing social and political institutions, existing religions, existing morality, represented universally a decline from primitive perfection and purity, how much worse would be the outlook than it is now, when we regard advance as the normal course, and degeneration as exceptional! Let any one who is disposed to think despairingly of the average morality of the present day turn, not to some sentimental idealization of the past, but to impartial accounts of what have been called "the Ages of Faith"; or let any one who is disposed to think despairingly about the tone of our present political controversies turn back to the days of Sir Robert Walpole, and mark how much progress has been made in the interval. A study of "the good old days" is a very excellent corrective to pessimism about the present and the future. Our opinion of the badness of the times in which we are living is largely due to the fact that we have come to consider as evil many things which our predecessors accepted as matters of course. But this critical spirit is one of the very conditions of progress.

This social faith is based, however, not only on knowledge of the past, but, as we have already seen, 
on that social instinct which links together not only those who are living, but "those who are living, those who are dead, and those who are to be born." On the instinct alone, though it suffices as a motive for the conduct of mankind in general, we could not base a reply to the pessimist; for he would say it is the delusion, from which reflection sets us miserably frec. But that inference is only possible to those who (like Oriental mystics) are ignorant of social development or (like their Western imitators) ignore it. As this instinctive solidarity of mankind rises more and more into a consciously accepted principle, we have the very force that is needed for a social faith, for an ethical religion. Neither logically nor morally can we isolate our lives and conduct from the lives and acts of others. The primitive instincts which made man a social animal, more even than the ants and the bees, reappear as the gospel of brotherhood, as the new commandment that we love one another.

\section{III.}

When it is said that morality must be based on faith, this is very commonly understood to mean that we must at least have a practical certainty of the existence of God, of Free Will, and of the Immortality of the Soul. It is supposed that, though these ideas 
are incapable of theoretical proof, a belief in them is a necessary condition of morality. If morality, however, cease to be regarded as a matter between the soul of the individual and God, and come to be regarded, as we have been regarding it, as necessarily of a social character, we must make it clear that in a certain sense of these great religious ideas, instead of being beneficial, they are even hurtful to morality, while in another sense they may be accepted as an expression of principles practically recognized in all right action. I can only now put this very briefly. The faith which, as we have seen, gives its force to social effort, requires a perpetual recognition, in thought and feeling, of the solidarity of the human race-in other words, of the continuity of moral causation. Whoever thinks that his conduct, which he may call only self-regarding, does not affect other human beings is denying the basis of morality. Now the idea of God has, alas! often served to sever this feeling of community with other men, instead of serving as the symbol of that unity. Where people, instead of mereiy professing to believe in miracles, actually do believe in direct Divine intervention, plague-stricken crowds throng churches for prayer instead of cleansing the filth from their streets and houses. Intolerable evils are calmly accepted as the judgments of God's anger, when they are really 
due to human negligence, human selfishness, and human ignorance. When God's name is used to justify oppression and cruelty, and to consecrate resistance to the cause of human progress, an indignant atheism may well seem the more pious creed; but if the name of God be used for what is best and holiest in human nature, need we avoid the sacred name as the expression of our moral ideal?

"'Tis God Himself becomes apparent, when God's wisdom and God's goodness are displayed, For God of these His attributes is made."

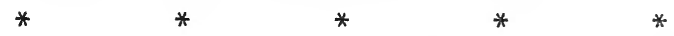

"God's wisdom and God's goodness-Ay, but fools Misdefine these till God knows them no more. Wisdom and goodness, they are God! - What schools Have yet so much as heard this simpler lore ? This no saint preaches, and this no church rules; 'Tis in the desert, now and heretofore." 1

The idea of Free Will has again and again been used in denial of this very fact of the continuity of moral causation. How often have measures of social reform been opposed on the ground that they weakened individual responsibility-as if men's characters were perfectly isolated phenomena, and not affected at every moment by their antecedents

1 Matthew Arnold, Sonnet on The Divinity. 
and surroundings! Man's freedom consists not in a mysterious exemption from the law of cause and effect, but in his capacity for thinking and so rising above the mere blind processes of nature.

And may not the idea of immortality be a pre-scientific way of envisaging this continuity of moral causation? It is not only the great and famous whose deeds and thoughts live on after them: every act of every one of us-nay, every thought and feeling exercises its influence for better or worse on those who come after us. "The growing good of the world," as Gcorge Eliot has beautifully expressed it, "is partly dependent on unhistoric acts; and that things are not so ill with you and me as they might have been is half owing to the number who lived faithfully a hidden life, and rest in unvisited tombs." If this idea were more generally recognized, people would be less ready to neglect the consequences of what they do in this life, while endeavouring to secure their personal safety in another, and less ready to tolerate misery here on the understanding that it will be compensated in a happy land, far-very far-away. We have no right dogmatically to deny anything that does not directly contradict what has been discovered to be true; and if we feel able to entertain the hope that all the unfulfilled promise, which is one of 
the saddest things in human life, may somewhere and somehow find fulfilment, we must on the ground of scientific truth, as well as for the sake of practical ethics, take care that this hope is held in such a way as not to conflict with a recognition of the unbroken chain of moral causation here. We must still face our practical problems, as if there were no future life to redress the wrongs of this, knowing that, if in any sense there is a future life, there can be no better preparation for it than in "being faithful over a few things" here and using rightly the talents entrusted to our keeping.

It is very noticeable how, even within the circles of the old creeds, the teaching, which made the everlasting destiny of the individual soul depend upon certain pious acts or emotions at the moment of death, has given place to the thought of the future life as the continuance of an education begun in this. It makes a great practical difference whether morality is based on the sanctions of heaven and hell or whether the fact of the incompleteness of the highest moral effort here is used to suggest a hope that nothing good may be altogether lost. This moralization of the old idea is, in great part, due to the teaching of our poets, especially of Tennyson and Browning. That other poet whom I have quoted, Matthew Arnold, has in a sonnet 
on immortality uttered the same manly and vigorous creed about the value of human life and human effort.

"The energy of life may be

Kept on after the grave, but not begun;

And he who flagg'd not in the earthly strife,

From strength to strength advancing-only he,

His soul well-knit and all his battles won,

Mounts, and that hardly, to eternal life." 


\section{VIII.}

\section{FREE WILL AND RESPONSIBILITY. ${ }^{1}$}

THE question of free will and necessity is often spoken of as incapable of solution, and controversy on the subject is supposed to be interminable. Milton ${ }^{2}$ regards a discussion on free will as a fitting occupation for the more speculative of his fallen angels-a refined form of eternal punishment. On the theological aspects of the question, of which Milton was chiefly thinking, I do not intend to say much at present,- - the seeming contradiction between the Omnipotence and Omniscience of God on the one hand and the freedom of the individual human being on the other. I do not think that, even in the special region of theological controversy, that question bulks as largely as it did in the seventeenth century. The doctrines of predestination and election

1 Lecture to an Ethical Society, published in International Journal of Ethics, July, 1895.

2 Paradise Lost, Bk. II., 557, seq. 
nowadays occupy comparatively little thought even among those whose religious ideas are mostly due to Calvinistic theology. I do not suppose that, apart from a few old-fashioned students, many of those who are most zealous about what they call "evangelical truth," consider the differences that separate Wesleyans from Calvinistic Methodists, Presbyterians, Baptists, and Congregationalists. One does not hear of Arminianism as a dangerous heresy at the present time; on the contrary, the defenders of orthodoxy seem often to forget that there was ever a suspicion of heresy attached to the assertion of man's free will. "Free will," in some undefined form or other, is usually supposed to be an essential doctrine that the champions of religion and morality are bound to maintain against the doctrine of necessity which is asserted by the champions of science. The "antinomy," or contradiction in thought, which troubles the modern mind, is not expressed in the form of an opposition between the eternal decrees of the Almighty on the one side and on the other the freedom of the human will, which is supposed to be implied in man's responsibility to God; but in the form of an opposition between the necessity of the causal nexus, which is presupposed by all the sciences of nature and of human nature on the one side, and on the other the freedom of 
the human will, which is supposed to be implied in man's responsibility even to his fellow-men. From a metaphysical point of view the necessity of nature may seem to be only an element in the eternal decrees of God; but it is the requirements of science and not the requirements of systematic theology which seem to trouble the present-day defenders of free will. There is an appearance of conflict between what is scientifically true and what is supposed to be good moral doctrine. Now an opposition between science and morality, if it is a real opposition, is a very serious matter; and it is an opposition which people cannot escape, as they think they escape the older form of the difficulty by simply disregarding theology and metaphysics as a futile waste of thought. It is worth while attempting to discuss it in order to see whether the opposition is a real one or not, and whether it may not be due to some misunderstanding of the term "necessity" on the one hand and of the term "moral responsibility" on the other. We are always too apt to discuss whether a thing is true or not, without asking first what it means and whether it means anything at all.

First of all, then, let us see what " necessity" means as postulated by science. It means nothing except the necessity of logical sequence. $A$ is the cause of $\mathrm{B}$; if $\mathrm{A}$ happens, $\mathrm{B}$ must happen,-i.e., 
from A we can infer B. If you throw a ball up in the air, it must come down again. The "must" here is not the "must" of command, as if there were some despot outside the whole universe who arbitrarily interfered with what, apart from his interference, would be the course of events we might reasonably expect. The "if . . must" is simply an expression for the course of events which we may and do reasonably expect. The necessity of natural causation is presupposed by all scientific investigation; but this presupposition is identical with our presupposition that nature is an intelligible whole, a universe, and not simply a chaos of isolated and disconnected events. Our presupposition in interpreting nature is simply that nature is capable of being interpreted. There can be no science of nature unless we do assume that nature is intelligible and coherent. We understand very little of nature as yet; a great deal we human beings may never be able to understand. But all science proceeds on the assumption that phenomena are connected together in such a way that if, and when, we are sufficiently acquainted with the conditions under which an event happens, we can predict the happening of that.event, whenever the conditions are fulfilled. The statement of a scientific "cause," the statement of a law of nature, is never strictly 
accurate unless we put in the "if," or perhaps several "ifs." If you throw a ball up in the air, it must come down again, if nothing interferes with gravitation. If the ball should alight on the roof of a house, or be caught in the branches of a tree, or by the hands of a human being, it may not come down to the earth so long as these obstacles are in the way. If you swallow a sufficient quantity of poison you will die, unless you can have a sufficient antidote administered soon enough; and so on.

Now, if there is to be a science of psychology dealing with the phenomena of the human mind, if there is to be a science of sociology dealing with the phenomena of human society, the principle of "necessity" must apply to the phenomena of human life in the same sense in which it applies to the phenomena of nature, but in the same sense only. When it is said that a frequent experience of two phenomena in immediate combination-say a double knock and the postman delivering letterswill lead to a mental association being formed such that the thought of the one phenomenon tends to recall the thought of the other phenomenon, it is not meant that at any given time you will necessarily think of the postman, but only that if you hear a double knock you will most probably think of 
the postman, unless you happen to have a playful friend who imitates the postman's knock, or unless there be some other counteracting cause to interfere with the association. So, if it is said that centuries of oppression and misgovernment tend to incapacitate a people from managing their affairs well when they first obtain their liberty, it is not meant that any given people must necessarily mismanage their affairs, but that under such conditions, unless their leaders show conspicuous energy and ability, a people are most likely to do so.

The opponents of " necessity" generally confuse it with fatalism. The difference between the necessity which I have been trying to explain and fatalism is just the difference between a statement of what under certain conditions may be foreseen and a statement of what must happen whatever the conditions may be. The necessitarian says, as every reasonable person might say, If you have sufficient ability, and if you have a sufficiently good training, and if you keep your health, you will succeed in your business, unless some particularly unfavourable combination of circumstances is against you. The fatalist or the fortune-teller predicts success irrespective of all conditions-in spite of all conditions. You are born under a lucky planet, you have certain lines on your hand, therefore you must 
succeed. Necessity means an orderly, intelligible world in which like causes produce like events. Fatalism or fortune-telling implies a chaotic world in which events may happen anyhow, or, at least, in which there are arbitrary interferences with the orderly sequence of events. Fate is thus the very opposite of necessity.

J. S. Mill sought to avoid the misleading associations apt to be connected with the word "necessity" by calling his theory not "necessitarianism," but "determinism." I do not think anything was really gained by the substitution of the latter term. It is quite as capable of gathering misleading associations round it as the other. To say that the will is "determined" by motives, and that these are "determined" by the character and circumstances of the individual, and so on, may be misunderstood to mean that some outside force intrudes and overrules the intelligible connection between cause and effect. For these misunderstandings, it must be admitted that necessitarians or determinists are a good deal to blame. They have often spoken as if the laws of nature were some despotic external authority against which man struggled in vain; they have ignored the fact that in so speaking they were opposing man to nature at the very moment when they were professedly 
reducing him to a part of nature, and they have ignored the fact that nature, including human volitions, is not the same as nature exclusive of human volitions.

I pass now to the other side of the antinomy. What is meant by free will? If we define free acts as those acts (of course, thoughts, volitions, etc., are "acts") of which the cause is in the agent himself,-a definition of "the voluntary" which satisfied Aristotle and St. Thomas Aquinas,- - there is no conflict between necessitarianism, as just explained, and free will. But such a definition is very wide and general; "the cause being in the agent" is a phrase that needs further analysis: (I) Where the cause of some movement of a person's body is external to the person-i.e., where the person is not properly an agent, but is only a passive object or instrument,-there, clearly, there is not "freedom," nor is there responsibility. If you are knocked down by the fall of some scaffolding, or if you are seized by a couple of policemen and carried off to the policestation, you are not a free agent in falling down or in being carried off, and you are not held directly responsible for falling down or for being carried off, though you may be responsible by going near the scaffolding or for arousing the suspicions that have led to your being arrested.

(2) Where the compulsion 
exercised is not directly a physical compulsion, the case is more complicated. If a brigand holds a pistol at your head and demands "Your money or your life!" your handing over your purse to him is obviously a voluntary act in a sense in which we could not apply the term to your having the purse torn from you by force. In the one case you do not act, in the other you do, though under terror of physical compulsion. Responsibility enters more largely into this second case than into the first. Still, the responsibility does not seem complete. The person who does even wrong or base acts under fear of death or of great pain or suffering to himself or to others may be excused in a way in which he could not be excused if these threats of violence were absent. Yet there is no absolute gap between the handing over a purse to the brigand who holds at your head a pistol, which you know to be loaded and which you know he is likely to use, and assenting to a disagreeable arrangement through a remote fear of possible unpleasant consequences to yourself or to other persons ; both are voluntary acts, "free" acts, in the sense of being acts springing from your own volition to move your muscles. But both may be called "involuntary" acts in the sense of being acts that you do with 'reluctance and with a feeling of pain and aversion. (3) We are only said to act 
quite freely, quite voluntarily, when the act is one that we do "with our whole heart," one that we choose not only in the sense that it is our act, for which we are in some degree responsible, but in the sense that we put ourselves into it, so to speak. For such acts, acts which are the outcome of our inclinations, we are obviously responsible in the fullest sense.

Now, so far as this goes, there is nothing yet to conflict with the statement that our volitions are due to causes in the same sense-and in the same sense only-as any other events are. Fear of pain, inclination towards an object, are causes of our volition in the same sense in which rain and sunshine are causes of the growth of plants. "Yes," it may be said, "but the more important cause is left out in these statements. The plant's own nature is among the causes of its growth,-a rose will not grow into a thistle,-and so the individual in each case is the most important and the real cause. The external circumstances are only the occasion of his acting." But the plant's own nature, the person's own nature are not theoretically incapable of further analysis, however difficult or impossible at present it may be to understand them. Just as in the Indian mythology the world is supposed to rest on an elephant and the elephant on a tortoise,- 
but there the search for causes comes to an end, -so in practical matters we are often contented with a very short exploration of causes. The self choosing how to act, choosing sometimes against inclination and sometimes with inclination, is the point beyond which we do not go in the ordinary analysis of conduct, which is sufficient, e.g., for the procedure of the law courts. When conduct is brought home to a person as the result of his own choice, he is held responsible for it. But where the lawyer may be content to stop, the psychologist and the moralist must go farther, and so must any person conscientiously examining his own conduct. Why did we choose this course rather than the other? We may wonder, perhaps, how we could have been so foolish; but if we are quite candid with ourselves, and have sufficiently good memories and sufficiently clear insight into our own habits of thinking and feeling, we shall discover what it was that made us choose the course we did. There is a fallacy of retrospection, if I may so call it, which is very apt to vitiate our examination of our own conduct in the past. We suppose ourselves back at the moment of choice with the same knowledge and experience that we have acquired since, in part as the result of that choice and of its consequences; and, besides, we suppose 
ourselves back at the moment of choice with the possible alternatives spread out before us in the same clear, steady light as that in which we are now looking on them. We forget that emotion remembered in tranquillity is a very different thing from emotion as actually felt. Now this familiar fallacy of retrospection seems to me to have a good deal to do with the belief that our choice is something undetermined and arbitrary; we picture ourselves in a calm and indifferent mood, surveying the possible logical alternatives, and we are loth to recognize that in the frame of mind in which we were at the moment of choice our choice was the inevitable outcome of that frame of mind, in the same sense in which an explosion is the inevitable outcome of a match applied to a cask of powder. If the match had gone out before it touched the powder, or if the powder had had its quality affected by damp, the result would have been different; and so it would have been with our conduct if our frame of mind had been altered. It may be seen here how, not determinism, but indeterminism is allied to fatalism. Indeterminism, like fatalism, supposes a want of continuity between different parts of psychical experience. To say that I must inevitably choose in a particular way, whatever frame of mind I am in, is to assert that an event is 
independent of its antecedent conditions. To say that I am equally able and equally likely to choose in one way or in its opposite, although my frame of mind is of a certain sort, is to assert, also, that an event is independent of its antecedent conditions. The necessitarian or determinist theory asserts that, if my frame of mind is of a certain sort, certain consequences will follow; it implies a connection between cause and effect. In other words, the motives of action are asserted to be causes of the same kind, so far as inevitableness of sequence and possibility of prediction are concerned, as the causes of physical events; and it is implied that if we could analyze with sufficient care we should always be able to see how volitions were the outcome of motives, and how motives were the outcome of our character and circumstances, and how our character was the outcome of previous acts and abstentions from acting, and so on.

The opponents of determinism are alarmed by this chain of cause and effect leading backward into infinity, and they try to stop somewhere and to find a real beginning. (I) The boldest attempt is to try to break the chain at the nearest link, and to say that we are able to act without motives. (2) Most "libertarians," however, nowadays disclaim this theory of absolute indeterminism, and say that 
we do not act without motives, but that we can make our own motives. "The will is as the strongest motive is," but it is we who make a certain motive the strongest. Now this sounds much more plausible, and is in less manifest contradiction with science than the first theory. But the assertion that we can determine which motive shall be strongest does not necessarily conflict with anything that the cautious determinist maintains. In urging that motives are the outcome of our character as acted on by circumstances and reacting on them, the determinist allows the character of the individual-i.e., the real person-to be a cause of his motives. To assert that you can only tell how a person is likely to act if, and so far as, you know his character, is to assert that the motives are not external forces by which the individual is blindly pulled or pushed, but that they are the outcome of the person's own real self as that has come to be. If, however, the libertarian does not concede this, but insists that we come to an absolute beginning somewhere, he is just like the mythologist who allows that the world rests on an elephant and the elephant on a tortoise and then stops. $\mathrm{He}$ hesitates to assert directly that we can act without motives, but if he practically asserts that there are certain actions farther back-viz., volitions-which 
are independent of motives, he only kicks indeterminism out at the front door to let it in again at the back. Thus, so far as this second theory differs from that of the determinist, it is only the first theory over again.

(3) There is a third view which is sometimes maintained-e.g., by Dr. Temple in his Bampton Lectures-that we are very seldom "free" in the full sense of acting apart from and contrary to motives; but that occasionally a miracle takes place, the chain of causation is broken through, and the will is for a moment free. If this only means that people often do unexpected things, or that by a great effort a person may escape from the bondage of a habit, it is true enough; but the unexpected is not that which happens without a cause, but only that of which the cause has been unforeseen or that of which the cause may remain unknown. Such occasional freedom would be the same thing as "chance"; and for scientific thought chance is only a name for our ignorance. When a scientific biologist allows himself to speak of spontaneous or accidental variations, he only means variations of which as yet the cause is unknown. If the doctrine of occasional freedom means anything more than the happening of the unexpected, it implies occasional indeterminism. So that we have really only one 
theory to discuss-viz, that of indeterminism, or acting without motives-in such a way that prediction is not merely practically, but theoretically impossible.

Now this theory is often supposed to be that of "the plain man," of the person who is unsophisticated by metaphysical speculations or scientific hypotheses. So far from this being the case, it would be nearer the truth to say that the theory was an invention of some of the schoolmen. Duns Scotus and William of Occam asserted that the Divine will and the human will were both "free" in the sense of having an arbitrary freedom of choice. The plain man is led to think that the free will theory is his theory, simply because he does not face the whole problem; he is content with one tortoise under his elephant, and he stops there. Furthermore, he is repelled by the theory of determinism, because he is made to believe that it means fatalism. In all our actions, including volitions, for which we are responsible, there must be some motive determining our action. If we say a person acted without a motive, and yet hold him responsible for his action, we are speaking inaccurately. We may mean that his motive was not such as would have influenced a reasonable human being; and by this we probably mean that he had no motive such as would have influenced ourselves. That every action for which a person 
is held responsible must proceed from a motive is implied in the old Roman legal question, so often misunderstood and misapplied, Cui bono? - i.e., Who benefits by it? If a person is accused of a murder, and it is impossible to see any motive which could have induced him to commit this murder, a presumption is created in favour of his innocence or else, we should add, of his insanity. ${ }^{1}$

When we find ourselves without a sufficient motive to decide our choice, we may ask some one else to decide for us, or we may "toss up." But our decision to "toss up" is not itself unmotived. It is due probably to the discomfort of indecision, the feeling that we are wasting time, or something of that sort. Suppose I am going out for a walk, and cannot make up my mind whether to turn to the right or the left; I may purposely let my decision depend on some mere "chance" in order to start myself definitely in one direction.

In arguing for the truth of determinism as against indeterminism, there is no need to deny the obvious psychological fact of indecision. But it seems rather a strange thing to think that indecision is a necessary characteristic of moral and responsible

1 The nature of insanity I need not here discuss. No libertarian psychologist is likely to wish to rest his case on the conduct of lunatics. 
action. The plain man, who is an honest man, would rather resent being told that, when he found a purse belonging to somebody else, nobody could really tell whether he would keep it or restore it to its owner. If the honest man is a quick-tempered person, you had better get out of his way after telling him that. There are, of course, "doubtful characters"; but those are just the people on whom the police have to keep an eye, in order that fear of the policeman may form a stronger motive than the temptation to pick conveniently accessible pockets. The people who are constantly wavering between right and wrong are, surely, not the only class of persons who can act morally and be held responsible for their actions. As Mr. Bradley has very ingeniously put it, it is a strange way of proving man to be accountable to make him out to be an altogether unaccountable creature. ${ }^{1}$ What we call the "reliable" person is just the person whose actions you can forecast. Would it not be absurd if the most satisfactory person morally were just the person who through want of indecision was not properly responsible?

Of course, I do not mean that the mere facility of predicting a person's conduct proves that he is 
responsible. A person subject to some habitual delusion may be quite certain to act in a particular way under a particular set of circumstances. A dipsomaniac may be certain to get drunk when liquor is placed in his way. A suicidal maniac may be certain to cut his throat if knives are left about when the fit is on him. In these cases particular actions follow particular external stimuli, just as a plant turns to the sunlight or a cat springs at a mouse. The rational will of the man is temporarily or permanently, in certain respects at least, in abeyance. Mere facility of prediction does not necessarily imply responsibility; but the power of predicting conduct is not inconsistent with responsibility. On the contrary, as I have just been urging, the thoroughly upright and responsible person is the person whose conduct can be predicted with more certainty than the conduct of the person of weak and unsettled character.

If we appeal to the plain man-i.e., to the ordinary experience and practice of people who are not interested in attacking or defending a philosophical dogma-it is obvious enough that we are constantly in the habit of making fairly successful predictions about human conduct. When we make engagements with some people, we know that they will be on the spot punctually to the 
minute; other people we know are almost equally certain to be behind time. If you arrange a picnic, you can generally be more certain that the people who have promised to come will turn up than that the day will be fine-in Great Britain. That is to say, we can predict human conduct in some matters with greater certainty than we can predict the weather. When it comes to forecasting the conduct of human beings on a large scale, the risk of failure is diminished. A shopkeeper who lays in a stock of goods for the season is predicting that a certain number of persons, more or less, will desire to purchase a certain quality and quantity of goods. He knows that a certain way of displaying his goods in the shop-windows, or certain forms of advertisement, will increase his sales. The whole huge advertising business, which varies the ugliness of some of our streets and railway stations and disfigures the beauty of much of our scenery, is a proof of the possibility of predicting human conduct and of the fact that volitions are the outcome of motives.

Some people would indeed admit that we can predict the conduct of human beings in the mass or on the average, but would urge that the impossibility of precisely predicting how any particular person will act on any particular occasion allows a 
loophole for free will in the sense of arbitrary, undetermined choice. Now it is quite true that the most experienced shopkeeper cannot certainly predict that $\mathrm{A}$ or $\mathrm{B}$ will buy particular commodities; he may be more certain about what $A$ will do than about what $B$ will do, because he knows A's usual tastes better, or because $\mathrm{B}$ is by nature a more capricious customer than A. But on the average he may forecast a sale of a certain quantity of goods. In this uncertainty of particular prediction, however, there is nothing that is peculiar to human conduct. Of a given packet of seeds you may predict that 50 per cent. will come up, of another packet that 70 per cent. will come up, etc.; but you cannot predict certainly that any particular seed will come up, though an experienced eye may see that this particular sced is more likely to come up than that. The principle of averages applies to voluntary human actions just as it does to any other natural phenomena, and it is vain to look for "free will" lurking in the holes and corners of incomplete and inaccurate calculations. An argument from the fact that predictions have only a rough accuracy would prove too much, for it would prove that turnip-seed had free will as much as men and women. As I have already had occasion to say, chance, if we are thinking carefully, is only a name for our ignorance. 
That we cannot in any given case make a certain prediction does not prove that events happen without a cause, "spontaneously," but only that we do not know the facts sufficiently. More perfect knowledge, which we, of course, may in this particular case never be able to obtain, would make prediction possible. As I said at the outset, the necessity of causal connection means "IF A, then B," and if we are mistaken in thinking $A$ is present, we should of course be mistaken in expecting $B$, unless some other cause were present from which $\mathrm{B}$ could arise.

It is often supposed that the admission of determinism makes punishment unjust, and necessitarians have sometimes used language which would imply that that was the case. Now, first of all there need be no practical difficulty in the matter, provided that punishment be understood to have in view, first and at the very least, the protection of society from injurious individuals; secondly (what is really a part of the first purpose of punishment), a deterrent effect on the minds of persons likely to be tempted to crime; and, thirdly, when it is possible, an educative effect on the mind of the criminal himself. If a theological necessitarian murderer were to argue, "It was predestinated that I should do this murder," the judge could reply: "It was also predestined that you should be hanged; you must not isolate one 
event and suppose that to be predestined, while you suppose that other events happen contrary to the plan of the universe as a whole. And, furthermore, you must observe, it was not predestined that you, being a most excellent and valuable citizen, should in some uncaused way commit a crime, but that you, being a dangerous character, should commit this crime, and hence it is expedient for society to have you removed." If our murderer were a psychological determinist, and argued that, his character and circumstances being what they were, it was inevitable he should commit this crime, the judge might answer, "The severest penalty of the law is enforced in order to give a very strong motive to people like you to deter them from yielding to the temptation to do criminal acts." The criminal, the socially injurious person, is a diseased member of the body politic, and must be cured or amputated. I do not see that the necessitarian theory raises any difficulty about the rightness and social necessity of punishment; it does, however, call attention to the importance of considering very carefully what kinds of punishment are really the most efficient for the purposes of social well-being. Thus, punishments which are not really deterrent are inefficient punishments ; they do not sufficiently protect orderly and law-abiding persons against wrong-doers. 
Punishments, on the other hand, which are so severe and cruel that they make juries reluctant to bring in a verdict of "guilty," are inefficient punishments, because they enlist the moral sentiments of the community against, instead of in favour of, the laws of the land, and they lead to dangerous criminals being let loose on society by unjust verdicts of acquittal. Again, punishments which make the criminal worse instead of better are inefficient punishments. Punishments should be educative, if possible-i.e., if the protection of society can be sufficiently secured (that is always the primary consideration), it is better to try to turn a bad citizen into a good citizen than to give up the problem. The highest, the divinest form of punishment is the educative, the purgatorial.

Some of the profoundest philosophers have urged that in the ethical idea of punishment the idea of retribution must be present; not vengeance, not the anger of an individual spending itself on the suffering of the offender, but the assertion of the majesty of the whole society against its rebellious part. Retribution, however, as so understood, seems to me only another, and, perhaps, a somewhat misleading, way of expressing what I have called the protective and the educative functions of punishment combined. The society must assert itself 
against its rebellious member, and, if the rebellious member is to be reconciled to the whole, he must recognize that the suffering which recoils on his head is a just suffering. The only theory of punishment which seems to me irreconcilable with a necessitarian theory of the will is an irrational theory of punishment; a theory of arbitrary and purposeless infliction of suffering; a theory such as may be found in some of the crude popular versions of Calvinistic theology, - the theory of Holy Willie's Prayer, according to which the vast majority of human beings are to be tortured for ever without being cured of their wickedness, while Holy Willie, being one of the elect, has, with equal purposelessness (provided that some very thorough change does not take place in his character), a happy time in heaven.

On the other hand, no rational theory of punishment seems to be compatible with any acceptance of indeterminism, even in the smallest degree or in the backmost corners of the soul. If a human being can will anything without motives or can will to will without motives, what is the use of supplying him with motives to abstain from evil? If there is anywhere any break or interruption in the causal chain, how can it be just to punish the part of the man that is affected by external and 
internal causes for what may have resulted from some intrusion of an uncaused will belonging to a totally different order of being? Indeterminism makes punishment useless and it makes it inexcusable.

A word must be said here about certain modern theories of crime which regard crime as a form of disease. Probably a considerable proportion of criminals, perhaps nearly all habitual criminals, are persons of abnormal nervous organization. But society must be protected against them, just as it is protected against dangerous lunatics; and if we drop the name "punishment," we must retain such modes of protection and cure as prove themselves most effectual; and, for the sake of the large number of persons of weak character who need strong motives to deter them from crime, we must have such modes of dealing with anti-social conduct as will serve as an effectual deterrent.

The determinist theory has suffered greatly from the crude and injudicious way in which it has too often been presented. Thus, when it is argued that human volitions are the outcome of "character" and "circumstances," both the advocates of the theory and its opponents are apt to think of these as if they were two determinate quantities which simply needed to be joined together in order to give the result. Now, in the first place, 
"circumstances" which we may speak of as being "the same" are not the same, as antecedents of volition, to persons of different characters. A purse lying on the road is one circumstance to an honest character and a quite different circumstance to a dishonest or "doubtful" character. Secondly, the character is not something fixed and constant, but is being continually modified, however slightly, by circumstances, or rather by its own reaction upon circumstances; for the character is the real "self," and to say that actions are self-determined is the same thing as to say that they are determined by the character. In speaking of the causal nexus, or the causal chain, we are too apt to be led away by the easy image or picture of a continuous series, as if the movement of causation were all in one direction, and as if causes and effects could always be clearly separated off as antecedents and consequents in time. And to this fallacious simplification of the problem we are apt to add another, by thinking of a combination of causes as if it simply meant the adding of two quantities, each of which remained unaffected in quality by the other. Now, this is a false way of thinking about any organic life-even the lowest (I need not here discuss whether it is correct even as applied to inorganic existences). A plant's growth, its "behaviour," is 
not a mathematical resultant of so much soil and air and sunshine added on to a given quantitythe plant's nature; the plant's behaviour is the outcome of its own nature as reacting on external stimuli. The environment in which a plant finds itself may determine whether it will have luxuriant or scanty foliage, and, within limits, whether its blossoms are single or double, nay, even whether they are darker or lighter in colour; but the environment will not turn a hyacinth into a tulip nor a blue hyacinth into a red one. That is the result of the plant's own nature. The power of variation which some plants inherit is very considerable, but it has definite limits. In the case of human beings the power of variation is very much greater, although even here there are limits.

This brings me to the subject of heredity; and it is in the name of the doctrine of heredity that the theory of necessity is often most aggressively asserted nowadays. This is partly the effect of a reaction. In the eighteenth century the significance of hereditary differences was too generally neglected in political and social theories. It was too often assumed by the "advanced thinkers" of those days that all human beings were born nearly equal and nearly similar, and that the enormous differences between them were entirely 
due to difference of education, difference of opportunities, difference of social surroundings. Nowadays, with biological theories in every one's mind, or, at least, biological phrases on every one's tongue, the tendency is rather the other way. Race is often treated as if it counted for everything and training as if it counted for almost nothing. The theory of heredity is often asserted in such a way that it seems only a new form of the Calvinistic doctrine of election. In this there is a good deal of exaggeration. Even among the higher animals below man much that is often supposed to be due to heredity is due to education. Thus, pigeons do not succeed in rearing families of young ones unless they have an experienced couple among them to teach the domestic virtues. As we go higher in the scale of animal intelligence, less, relatively, is due to inherited instinct and more to the social inheritance, -i.e., to education and environment. And when we come to man, the use of language and the existence of definite institutions make possible a storing up and transmission of the results of experience which is impossible among the lower animals. The brain of the civilized man is said to differ less from that of the lowest savage than that of the lowest savage differs from that of the highest ape; but the intelligence of the civilized 
man, his power of thinking, his power of controlling nature to his own ends, excels that of the savage more than the power of thinking of the savage excels that of the highest ape. What makes the difference? It is not merely heredity. It is the accumulated social inheritance of the civilized man, who is the "heir of all the ages." Thus, we think wrongly about human society when we regard its destiny as determined solely by natural selection and by heredity. Man is not the mere product of natural forces: he can think, he can reflect, he can turn round on the natural forces that have produced him and direct them to some extent; he can even defy them with some success-within limits, of course; and it can only bring disaster to forget these limits set by heredity. As the homely proverb says, "You cannot make a silk purse out of a sow's ear." You cannot make an Isaac Newton, a Darwin, or a Tennyson out of every child at the board-schools, not even if you give them free admission to the best secondary schools, free education at the universities, free access to the best libraries. But what you can do is this: you can make the average child into a more intelligent and more useful citizen than he could possibly become, if left unable even to read and write, and without any of the discipline of education. And the same is the case with the effect of moral 
surroundings. You cannot make every one into a saint or hero, but you can do a great deal to prevent degradation. Till the effect of good, healthy surroundings is tried, you cannot be certain how much of the vitiated characters you find is due to an incurable hereditary taint, and how much simply to the effect of a bad upbringing. It is moral cowardice and intellectual falsehood to throw all the blame on "nature" without trying what can be done by "nurture." And even with those who are proved to come of a hopelessly bad stock, cannot something be done by isolating them, to prevent a continual contamination of others and a continual propagation of the unfit? I cannot deal with that problem here. I only wish to point out that there is no real, scientific warrant for folding our hands and leaving everything to what we call "nature,"-which, as thus used, only means nature with the greater and the best part of human nature left out of it. For we must never forget that human thoughts, human aspirations, human ideals are as much a part of the phenomena which make up this causally connected universe as the instincts and appetites that are common to man and the other animals.

People sometimes speak as if free will were not true, or, at least, were incapable of being proved 
true for science, and yet were, in this same sense, a doctrine necessary for morality. ${ }^{1}$ Now this is a somewhat dangerous attitude of mind, which accepts a fundamental contradiction between science and morality. But is it so certain that the freewill doctrine is more favourable to the interests of morality than the necessitarian? Robert Owen urged the doctrine of necessitarianism in the interests of his endeavours after social reform. The free-will doctrine,- the notion that at any moment any human being is "free" to choose between right and wrong, and that all moral evil and a great part of the physical evil in the world are due entirely to the wrong choice of individuals who might equally well have chosen rightly,-this notion has undoubtedly helped to blind people to the necessity of putting individuals in good surroundings, of giving them strong motives to choose rightly. The free-will doctrine applied in this way has been bad for society. It is also bad for the individual. The idea that at any moment we are free to choose aright leads to a neglect of the fact that habits

1 This is not Kant's doctrine, but a caricature of Kant. Kant admits all that the necessitarian asks for. $\mathrm{He}$ only adds, though in a way that is open to many objections, that psychological necessitarianism leaves the metaphysical basis of morality unexplained. 
are gradually, though silently, growing up which may make it almost impossible for us to choose a year hence in the way in which we may still be able to choose now. We do not expect a plant to grow vigorous and strong under unfavourable conditions. We are too apt to expect human beings to do so. "Lead us not into temptation." What is the meaning of that prayer, if not that surroundings do act upon the will? And those who seek a good life must not only avoid temptations, but must get into healthy surroundings as much as they can. A negative morality is a one-sided ideal, and it is a very inadequate discipline for the soul. The great defect of ascetic morality has been, not its rigid system of discipline (we all need discipline in our lives), but its negative character. The good life is made to seem simply a series of denials, of abstinences. For the average human being this is a somewhat dangerous training, - apt to produce terrible reactions. It is not enough to cast out an unclean spirit and leave the house empty, however swept and garnished. Such a spirit is very apt to return with seven other spirits more evil than himself. Many very devout and serious persons, absorbed in their own religious life, have been slow to recognize this; and that is probably one explanation why such persons have so often 
failed more conspicuously in bringing up their children than more worldly persons who have had a considerable number of varied and healthy interests. "Satan finds some mischief still for idle hands to do" is an excellent warning even for those who have cast out Satan from their creed. It is a moral duty not merely to avoid evil, but to cultivate varied and healthy interests. And this is also the best way of avoiding evil. A morbid concentration of thought on the things that ought not to be done is apt even to lead to the doing of them. There is a good deal of sound moral doctrine to be got out of a full recognition of the truth which there is in psychological determinism.

At the same time there is an element of truth in the belief that free will is a morally useful idea, an element of truth which is neglected by most exponents of determinism: I mean the importance of getting people to think that they can do a thing. The idea of oneself as acting in a certain way becomes a new factor in the mind; it may attract desires and feelings round it, and so become a new motive determining conduct. A man may be turned from idle and evil courses by the image of himself as a good man and a useful citizen, provided, of course, this image of himself as acting rightly is not merely a piece of day-dreaming, but an ideal 
that stimulates effort. Herein lies the good of examples in morality. That "men of like passions with ourselves" should overcome difficulties and sloth and temptation restores faith in the possibilities of the human nature we share with them. But in all this there is no contradiction of scientific determinism. There is nothing in any carefully understood scientific truth inconsistent with the modifiability and adaptability of the normal human being-within limits, certainly, but limits which we have no right to fix too narrowly till every effort has been made. It is this modifiability of human nature which gives so much power to external influences whether good or evil.

Ideas which seem entirely to contradict freedom may have the same beneficial effect as the idea of freedom. The theological doctrine of prevenient and irresistible grace has helped those who have accepted it, and who have felt themselves "saved" by such grace, to change almost the whole course of their lives, believing that it was no longer frail, corrupt human nature that was acting, but God's omnipotence working in them to will and to do that which is good. Probably more persons have been helped to reform their conduct by a sincere belief in some such high Augustinian or Calvinistic doctrine than have been helped by a belief in the arbitrary power of choice at any moment. The 
latter seems to me only a safe doctrine in the minds of persons of good character who are likely therefore to choose aright, and whose confidence in their freedom is really a confidence in their strength. The theological doctrine of grace in its extreme form has also undoubtedly considerable dangers. It may lead to spiritual pride and contempt for ordinary "carnal" morality on the one side, and to despair and helpless misery on the other. But it contains, in a mystical and somewhat irrational form, the important philosophical and ethical truth that man as a moral being is raised above the merely natural; it accentuates just that element which the necessitarian theory, as ordinarily stated, leaves out,- the gap between man and mere unconscious, unreflecting nature. The protest of the advocates of free will against necessitarianism seems to me a protest, in a mistaken form, in favour of this neglected truth. Man thinks, and therefore his thoughts, his aspirations, his ideals, become a factor in his conduct and raise him above the mere passive instrument of natural (i.e., animal) appetites and impulses. The necessitarian too often represents men as merely passive, as merely a series of events; man is an agent, and is more than a mere series of events. He can act, to use a famous phrase, not merely according to law, but with a consciousness of law. 
To conclude, I must call attention to the ambiguity in the term "freedom" as applied to the will. Man is "free" in the sense that the actions for which he can be held responsible are the outcome of his own conscious self, and not determined by external causes. But this is only the negative sense of freedom. He is free in a higher sense only when he acts according to the dictates of his reason, when his reason determines the content of his volitions, when motives are not merely motives as distinct from mere impulses, but are such motives as his reason approves. In this sense of freedom there is no appearance even of an opposition between freedom and necessity. Freedom in this sense is opposed to slavery, and is identical with rationality. Freedom in this sense may be described as the end or aim of morality. In the other sense it is only its presupposition. Freedom in this higher sense is the very opposite of arbitrary caprice. It is the freedom, not of lawlessness, but of selfgovernment ("autonomy of the will," in Kant's phrase). We are not self-governing to start with, nor do we become so by being left to "the freedom of our own will,"-i.e., to the blind guidance of instinct and impulse. Self-government, so far as we ever attain it, is the result of training and discipline which must at first be given us 
by others, and can only afterwards be directed by ourselves.

Benjamin Franklin tells us in his autobiography how at one time he tried to form a band of young men united by no elaborate theological doctrines, but chiefly by the common desire of helping each other to lead good and useful lives-an "ethical society," in fact, in one at least of its aspects. To this society he proposed to give what seems to us the rather curious name of "The Society of the Free and Easy." "Free," he explains, "as being, by the general practice and habits of the virtues, free from the dominion of vice, and particularly by the practice of industry and frugality, free from debt, which exposes a man to constraint and a species of slavery to his creditors." Franklin had a somewhat prosaic way of preaching great and good causes, but he brings out in his odd title this important aspect of freedom,- that same aspect which Spinoza was thinking of when he identified "the slavery of man" with the strength of the passions and the freedom of man with the power of the reason. Free will in the sense of incalculable, unmotived caprice would not be worth having, even if it were an intelligible idea; free will, in this higher sense, is the will that can only exist by obedience to the dictates of reason. "Where there 
is no law there is no freedom" is a sound maxim in ethics as well as in politics. ${ }^{1}$

1 On the difference between the negative and positive meanings of "freedom" in ethics and politics, I cannot do better than simply refer those who are not already acquainted with it to the discussion of the subject in T. H. Green's Works, vol. ii., p. 308, seq. 


\section{VIII.}

The Antinomy of Theological or Psychological Necessitarianism and Free will, 200-202. The Meaning of "Necessity," 202-205. "Fatalism," 205-206. "Determinism," 206. "Freedom," 207-209; not inconsistent with Necessity, as Defined, 209-212. Various Forms of Free-will 'Theory, 2 I 2-2 r 5. Responsibility does not imply Indeterminism, 215-217. The Prediction of Human Conduct, 2I 7-22I. Punishment, 22I225. "Character and Circumstances," 225-227. Heredity, 227-230. Supposed Moral Utility of the Free-will Doctrine, 230-233. Power of Ideas, 233-235. Freedom as Rationality, 236238. 




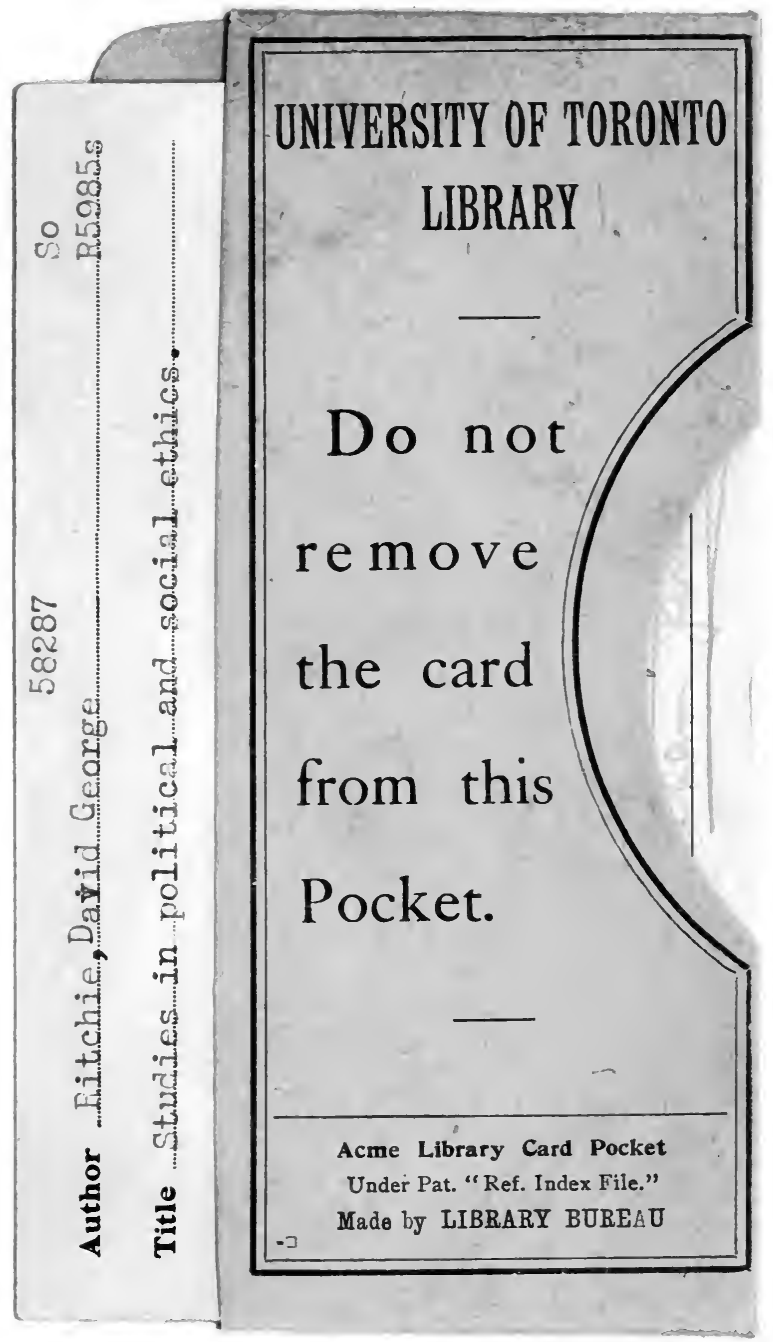


